

\title{
DESICCANT-BASED PRECONDITIONING MARKET ANALYSIS
}

\author{
J. Fischer \\ SEMCO, Inc. \\ A. Hallstrom, P.E. \\ The Trane Company, Division of American Standard \\ J. Sand \\ Oak Ridge National Laboratory
}

June 2000

Prepared by

SEMCO, Inc.

for

OAK RIDGE NATIONAL LABORATORY

Oak Ridge, Tennessee 37831-6285

managed by

UT-Battelle, LLC

for the

U.S. Department of Energy

under Contract No. DE-AC05-00OR22725 


\section{CONTENTS}

TABLES

1. INTRODUCTION: TASK 1 MARKET STUDY ….............................................................. 1

1.1 PURPOSE OF THIS OUTDOOR AIR PRECONDITIONING MARKET EVALUATION:. 1

1.2 PRELIMINARY POSITIONS AND ASSUMPTIONS

CONCERNING THIS STUDY

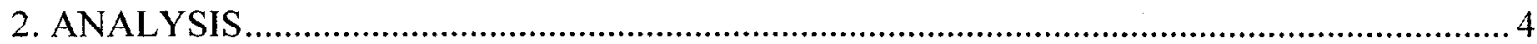

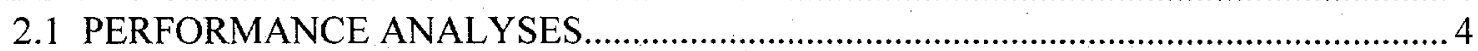

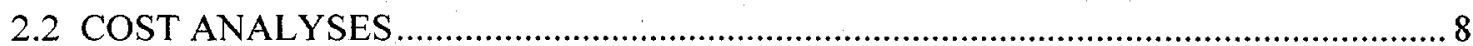

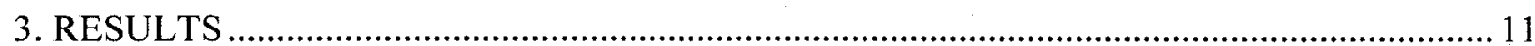

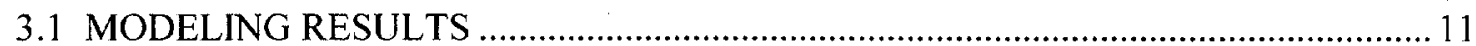

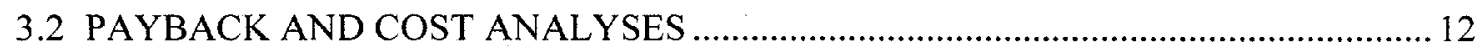

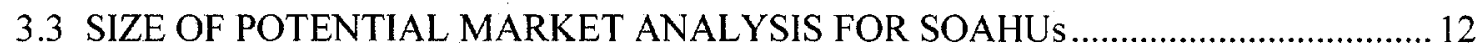

3.4 OVERALL ENERGY IMPACT ANALYSIS FOR SOAHUs …................................ 15

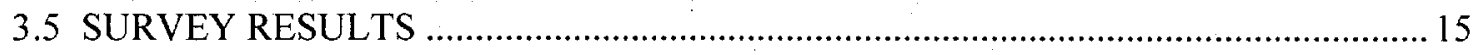

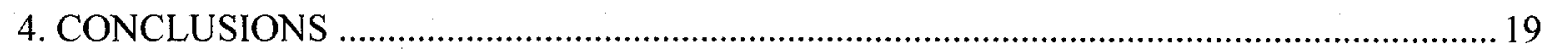

APPENDIX A. Sample Energy Bin Analysis Sheets for each SOAHU Approach

APPENDIX B. Detailed Specialized Outdoor Air Handling Unit Modeling inputs and Results for Atlanta and Desiccant-Based Cooling Modeling Data for Houston, Minneapolis, New York, and Orlando

APPENDIX C. Modeled Energy Costs for Selected Cities at Different Levels of Dehumidification

APPENDIX D. Sample Customer Survey Sheet

APPENDIX E. Final Market Segment Analysis Sheets 



\section{TABLES}

1. Markets and cities investigated for outdoor air preconditioning ............................................. 7 .

2. Utility costs (1994) of electricity and gas for the regions analyzed in this study ......................7

3. Impact of new ASHRAE weather data on a 20,000-cfm system in Atlanta.............................8

4. Selling price and physical dimensions of various preconditioning approaches at different airflow capacities ................................................................................................. 9

5. Simple payback of various preconditioning approaches at different airflow capacities

6. Size of potential outdoor air preconditioning market, segmented by application (all of the United States)

7. Business potential for various preconditioning products, segmented by market

8. Business potential for various preconditioning products, segmented by market

9. Survey responses for office buildings, nursing homes/hospitals, operating rooms, research labs, and fast-food restaurants

10. Survey responses for retail stores, hotels/dormitories, classrooms, and theaters/auditoriums 



\section{INTRODUCTION: TASK 1 MARKET STUDY}

\subsection{PURPOSE OF THIS OUTDOOR AIR PRECONDITIONING MARKET EVALUATION}

The primary purpose of this phase 1 marketing evaluation is to define the markets and applications that would best benefit from a design approach that uses a specialized outdoor air-handling unit (SOAHU) to "decouple" (or separate) the latent load associated with the outdoor air (or outdoor and space loads) from the sensible (cooling) load. This approach would allow down-sized conventional cooling equipment to handle the indoor sensible load. It can result in better humidity control and reduced energy consumption without significantly increasing the project first cost.

Key objectives include establishing the following:

- Which markets and applications will embrace an SOAHU approach? Which of the preconditioning system configurations identified in this study would most likely be used in each market?

- Which SOAHU benefits are most important to the individual markets, and are these benefits quantifiable and important enough to justify a first-cost premium to the facility owner?

- Which markets are best served by desiccant systems, both heat-regenerated and non-regenerated (total energy recovery) and why (Task 1)? Which desiccant system configurations need to be offered to effectively serve these markets (i.e., component arrangement, sizes, performance, construction, size, and price) (Task 2)?

- What is the estimated annual sales volume potential that could be targeted with a line of desiccant-based preconditioning products, both regenerated and non-regenerated?

- What are the current sales estimates of various SOAHU designs?

- Which market drivers (ASHRAE 62-89, new weather data, re-evaporation from direct expansion (DX) cooling coils, moisture storage within structures, demand reduction, dry ductwork, improved humidity control, etc.) are most important to the justification of the SOAHU approach? What training tools are most required to convey this to the field?

- Which desiccant-based cooling (DBC) system configuration shows the most promise to current heating, ventilation, and air-conditioning (HVAC) equipment manufacturers? The involvement of HVAC manufacturers may be crucial in construction of a laboratory prototype that may incorporate conventionally available hardware components. [Such a laboratory prototype is to be built as part of this total program (Phase 2)].

\subsection{PRELIMINARY POSITIONS AND ASSUMPTIONS CONCERNING THIS STUDY}

Only outdoor air preconditioning systems will be considered in this evaluation. The mass market required to justify a product introduction by one of the major HVAC equipment manufacturers was considered to be an important consideration in assessing the market potential of desiccant systems to handle outdoor air latent loads.

All available methods of handling this latent load must be evaluated against the merits of the regenerated desiccant system approach (DBC), because such an analysis will surely be done by the marketplace on a job-by job-basis. Only the markets that clearly benefit from the DBC approach and are justifiable without utility rebates will be considered viable markets in this study. 
Based on previous modeling experience, the desiccant cooling system performance used for this analysis is optimized for $\$$ ton and not for coefficient of performance (COP) or efficiency. This is because the marketplace will demand a "cost-competitive" and compact product, and most energy savings will come from demand savings and not reduced $\mathrm{kWh}$ consumption.

The modeling results for an active desiccant system show the annual Btu consumption can actually be greater for the active desiccant system than it is for the conventional approach. Even in areas where the cost of electricity is high and the cost of gas is low, the energy cost savings are relatively small, until the demand charge is factored into the analysis (most utility structures utilize a relatively low kWh-consumption charge and a sizable demand-charge element). An active desiccant system optimized for $\$$ ton of latent cooling is significantly less expensive than a similar system optimized for energy efficiency (the higher efficiency comes at the expense of lower wheel face velocities and thereby a much larger system size processing for the same airflow). However, because the two systems may provide a similar reduction in outdoor air latent load at design conditions, the peak electrical demand savings will be similar. Once again, because the modeling confirmed that most of the energy-cost savings are associated with the peak-demand savings and not $\mathrm{kWh}$ reduction, the active desiccant system optimized for \$/ton of latent cooling will clearly be the choice of the marketplace.

The weather data for most Phase I analyses used ASHRAE dry-bulb frequency groupings, or BINS, with corresponding wet bulbs because it was available when this work was performed. Phase 2 analyses will be based on ASHRAE outdoor air wet bulb BINs with a mean coincident dry-bulb temperature, because that more accurately reflects the latent load in outdoor air. Phase 1 will compare these two methods to quantify the resulting difference.

The cost comparisons for all of the system approaches are based on typical central-station air-handler selling prices so that a fair assessment can be made. These are mass-produced, pre-engineered, airhandling modules such as the current Trane Climate Changer ${ }^{\circledR}$ offering.

Reduced chiller capacity credits (for example) used are from component pricing provided by data obtained from literature available from the major HVAC equipment manufacturers.

Many markets will not require optimum-space humidity control and may be effectively served by straight non-regenerated desiccant energy recovery (no supplemental cooling and reheat) feeding conventional cooling systems. However, all performance comparisons in this study will assume that dry air at a "space-neutral" temperature (an air temperature range of $65-80^{\circ}$ ) is desired, (thereby providing a more favorable comparison to the $\mathrm{DBC}$ approach). The preconditioning systems are designed to provide dry air at a space-neutral temperature (i.e., close to that of the space) so that this air can be provided directly to the occupied space without overcooling. There are many cases where a conventional ventilation air-preconditioning approach needs to cool the air to remove the humidity, but sensible cooling is not required (i.e., $68^{\circ}$ and raining outdoors). As a result, outdoor airpreconditioning systems sold today are typically controlled to provide space-neutral air.

The air that leaves an active desiccant system is hot, so it needs to be cooled before it is introduced to a space. If hot air is provided, it will overheat the room, or, if it is provided to another more conventional air handling system, that system will need to expend energy to post-cool this pretreated (dehumidified) outdoor air stream.

To satisfy the "space neutral" requirements specified above, the modeling assumes that the conventional cooling approaches would reheat to $65^{\circ}$ and the active desiccant systems would be postcooled to $80^{\circ}$. This energy is factored into the analyses completed as part of this investigation. These considerations are shown in the range of air outlet conditions for the seven SOAHU options illustrated and discussed in the exhibit on the following pages. 
The projected size of the overall market and percentage allocation to SOAHU equipment and the various approaches come from market information provided by surveys of the major HVAC manufacturers and input from the marketing questionnaires provided to select consulting engineers, owners, sales offices, and SEMCO in-house and field sales staff.

All analyses assume that the DBC systems will be reliable and will perform as modeled, to eliminate the barrier of considering an unknown technology. 


\section{ANALYSIS}

As stated previously, the primary purpose of this marketing evaluation is to define the markets and applications that would best benefit from a design approach that uses an SOAHU to decouple the latent load associated with the outdoor air (or outdoor and space loads). This could allow down-sized conventional cooling equipment to handle the indoor sensible load. A further objective is to determine which of the available SOAHU approaches would most often be used in each market segment. Finally, based on the needs of the market segments showing the most promise for regenerated $\mathrm{DBC}$ systems, this analysis attempts to determinc what the product offering needs to be and how much business potential (\$/year) exists for the technology.

\subsection{PERFORMANCE ANALYSES}

This investigation studied seven SOAHU approaches for decoupling outdoor air loads. These approaches are described briefly, including simple schematics, in the exhibit "Preconditioning Approaches Analyzed by this Study." They include conventional cooling with reheat, conventional cooling with sensible recovery to provide free reheat, two total recovery approaches using nonregenerated desiccant wheels, and three approaches using regenerated desiccant wheels. Table 1 summarizes the nine markets investigated for each approach. It also lists the six cities chosen for analysis and the reasons they were selected. Table 2 lists the energy costs used for each city selected; these were obtained from a report sponsored by the Gas Research Institute that lists 1995 electric and gas rates.

Models were prepared for each SOAHU approach to allow for a comparison at different operating conditions, in different climates, and for different energy costs. Appendix A gives sample energy BIN analysis sheets for each SOAHU approach; for 2500-cfm, 7500-cfm, and 20,000-cfm systems; and for each of these city locations. Appendix B presents more detailed illustrations of each of the modeling applications for the Atlanta area. Also included in Appendix B are modeling data for the DBC approach for locations in Houston, Minneapolis, New York, and Orlando; these data highlight the impact that weather and energy cost have on performance of this option.

Results of this modeling for differing levels of pre-conditioning dehumidification are summarized as Cases 1 through 4 in Appendix C. Case 1' assumes preconditioning outdoor air to 50 grains, Case 2 to 65 grains, and Case 3 to 45 grains. Each of these cases assumes a consistent cost of energy. Case 4 was prepared based on delivering 50-grain air but uses the actual energy cost for each individual city.

In the second phase of this study, the new dew point weather data will be used to complete the final energy analyses for the most promising markets. For this study, dry bulb BINs with mean coincident wet bulb data were generally used. This provides a conservative estimate because it understates both the humidity content and enthalpy of the outdoor air volumes. In Appendix B, there are two examples of analyses for the conventional cooling/reheat, dual total energy wheel, and DBC approaches that use the new dew point weather data for Atlanta (see Appendix B). The impacts of using these design dew point data are summarized in Table 3.

To keep a consistent comparison in Table 3 , all regeneration and reheat that is not available from a source of waste heat is provided by a boiler burning gas at an efficiency level of $78 \%$. The second conventional system showing a run-around heat exchanger system is the most efficient way of using conventional cooling without desiccants. An example utilizing DX dehumidification and condenser reheat was not considered because the performance of the cooling system would have to be compromised to provide the amount of heat necessary for an all-outdoor-air application. This would make comparisons of energy efficiency impossible, because it could not provide the same supply conditions chosen for the analysis. More important, the run-around example provides a more energyefficient option, and therefore a good complement to the conventional approach, using vaporcompression DX for dehumidification with hot-water reheat (still a very common approach). 


\section{Exhibit: Preconditioning Approaches Analyzed by this Study}

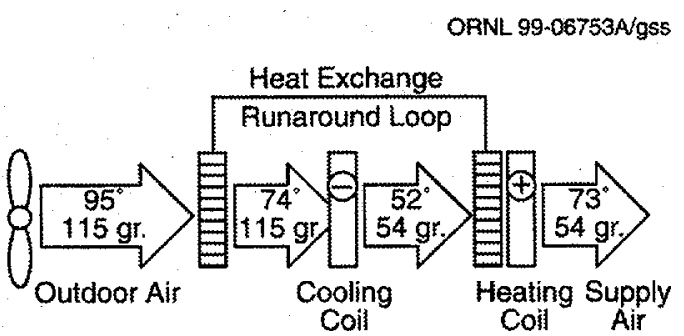

Options 1 and 2: Cooling and Reheat

This approach offers the lowest first cost in most cases and requires the highest energy consumption (Fig. 1). It is also the technology most familiar to the major HVAC manufacturers, and thereby the easiest to integrate into their manufacturing and marketing organizations. It is compact and does not require an exhaust air stream to operate. Adding a run-around coil or heat pipe improves performance. This option is limited in its ability to deliver low dew points, does not handle fluctuations in outdoor air moisture loading very well (when using DX), and offers no recovery in the heating or cooling modes.

\section{Option 3: Desiccant-Based Total Recovery with Conventional Cooling and Reheat}

This approach offers a more energy-efficient version of Option 1 (Fig. 2). It also improves the control of the DX cooling approach because it stabilizes the conditions introduced to the cooling coil. It provides for efficient heating mode energy recovery, which dramatically expedites the payback of the increased cost over Option 1. This approach significantly reduces the condensate on the cooling coil when compared to Option This option is also limited in its ability to deliver low dew points and requires an exhaust air stream to operate. Because it combines a supply and exhaust system, it is larger than Option 1.
ORNAL 99-06755NgSS

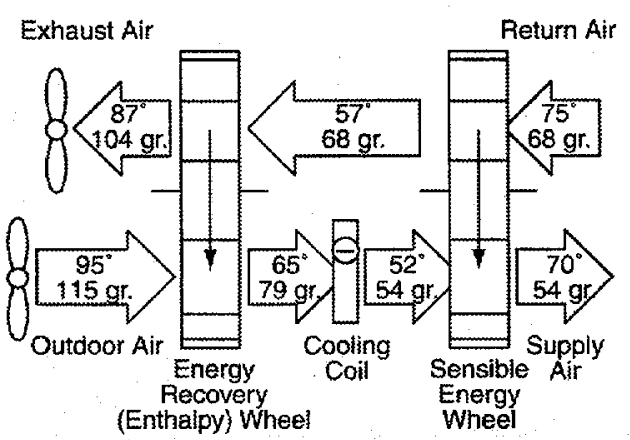

Option 4: Desiccant-based Total Recovery and Free Reheat with Dual-wheel Approach

This approach offers a very energy-efficient version of Option 2. It further improves the control of the DX cooling approach, making it an ideal application for DX despite the $100 \%$ outdoor air. It provides for free reheat via the sensible recovery wheel. It offers heating mode energy recovery. This approach minimizes the mechanical cooling tons required to dehumidify the outdoor air. This option is also limited in its ability to deliver low dew points and requires an exhaust air stream to operate. Because it combines a supply and exhaust system and a sensible wheel, it is larger than Option 2. 


\section{Option 5: Heat-Regenerated Desiccant-Based Cooling Approach}

This approach uses gas, steam, or waste heat to regenerate a desiccant dehumidification wheel, which eliminates the need for conventional cooling to remove moisture from outdoor air streams. A sensible energy wheel removes most of the heat added by the regeneration process and uses this heat to minimize the amount of regeneration energy required. This option can provide, in some climates, drier air than possible with conventional cooling approaches. Other advantages, such as dry cooling coils, airborne pollutant removal, improved economizer operation due to indirect evaporative cooling and reduced energy consumption over Option 1 are common. An exhaust air stream is beneficial

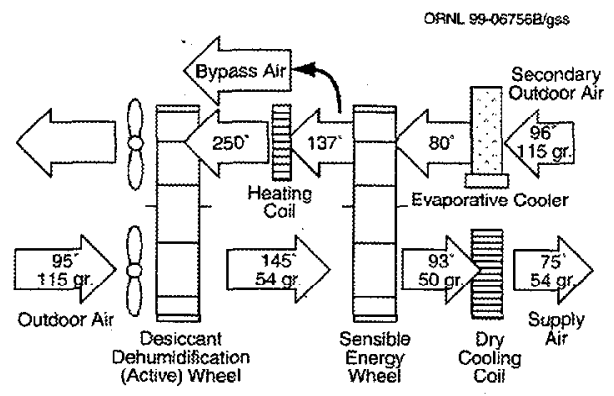
but not required for this approach, which is a key advantage over Options 2 and 3.

This option requires a more complex control system for optimization than do the previous approaches. Because the face velocities through the desiccant wheel need to be moderate to recognize the desired performance, the units are very large compared to Option 1. Because raw outdoor air is introduced to the dehumidification wheel, the heat generated is significant, making the second wheel essential.

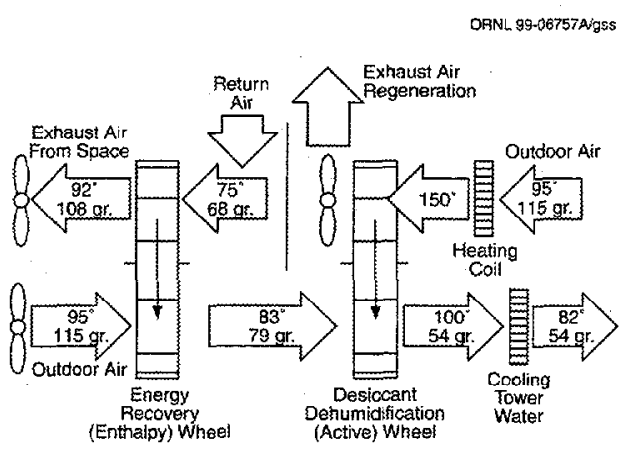

\section{Option 6: Heat-Regenerated Desiccant-Based Cooling and Desiccant-Based Recovery Wheel Hybrid Approach 1}

This approach uses gas, steam, or waste heat to regenerate a desiccant dehumidification wheel, which eliminates the need for conventional cooling to remove moisture from outdoor air streams. Because much drier air is introduced to the desiccant wheel than in the case of Option 4, much less heat is added to the supply air stream, making conventional post-cooling (e.g., from cooling tower water) feasible. Much lower dew points are possible, and this system is more energy efficient than Option 4. Advantages such as dry cooling coils, airborne pollutant removal, improved economizer operation as a result of indirect evaporative cooling, and reduced energy consumption over Option 1 are common. Full benefits of heating-mode total energy recovery are recognized. The secondary evaporative cooler, which is very important for Option 4 , is eliminated with this approach. From the standpoint of maintenance and IAQ concerns, this is an advantage. An exhaust air stream is required for this approach. The same challenges listed for Option 4 above apply.

\section{Option 7: Heat-Regenerated Desiccant-Based Cooling and Desiccant-Based Recovery Wheel Hybrid Approach 2}

This approach combines the best of Options 4 and 5 by integrating an additional sensible wheel after the dehumidification wheel to reduce the sensible load added by adsorption and, at the same time, reduce the regeneration energy requirement. This system provides a very high COP and low operating cost. This approach will be evaluated primarily for this reason.

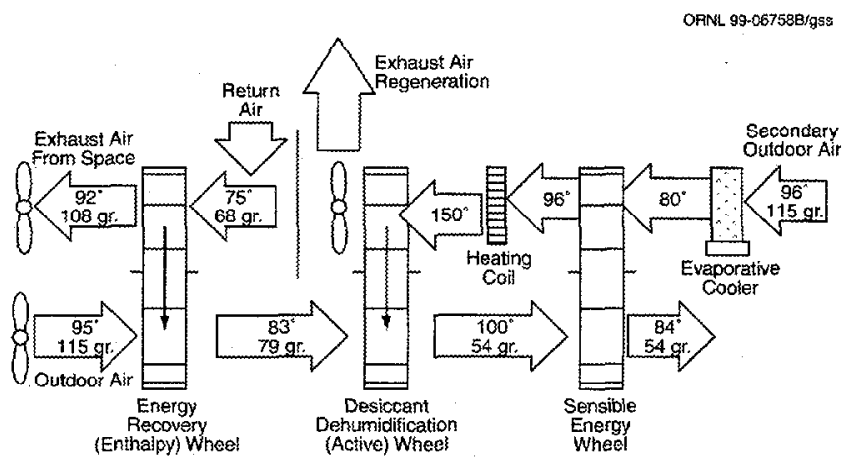

Once again, advantages such as dry cooling coils, airborne pollutant removal, improved economizer operation due to indirect evaporative cooling and reduced energy consumption over Option 1 are common. Full benefits of heating mode total energy recovery are recognized. An exhaust air stream is required for this approach. The same challenges listed for Option 4 above apply. Size and first cost are the big obstacles with this approach; however, it is very appropriate for designs where energy efficiency is most important and for combining with engine-driven chillers, for example, where waste heat is available and dry coils are desired. 
Table 1. Markets and cities investigated for outdoor air preconditioning

\section{Applications-markets}

1. Hospital operating rooms

2. Nursing homes and hospital areas other than operating rooms

3. Research laboratories

4. Quick service restaurants

5. Retail stores

6. Hotels, high-rise apartments, dormitories

7. School and university classrooms

8. Movie theaters and auditoriums

9. Office buildings

\section{Cities investigated for energy analysis}

1. Hot/humid, high-electric, moderate-gas costs (b)

2. Hot/humid, moderate-electric, moderate-gas costs (c, d)

3. Moderate humidity, high-electric, moderate-gas costs (b, e)

4. Moderate humidity, moderate-electric, moderate-gas costs (a)

5. Cities representative of different parts of the country:

(a) Minneapolis, MN

(b) Orlando, FL

(b) New York, NY

(c) Atlanta, GA

(d) Houston, $\mathrm{TX}$

(e) Los Angeles, CA

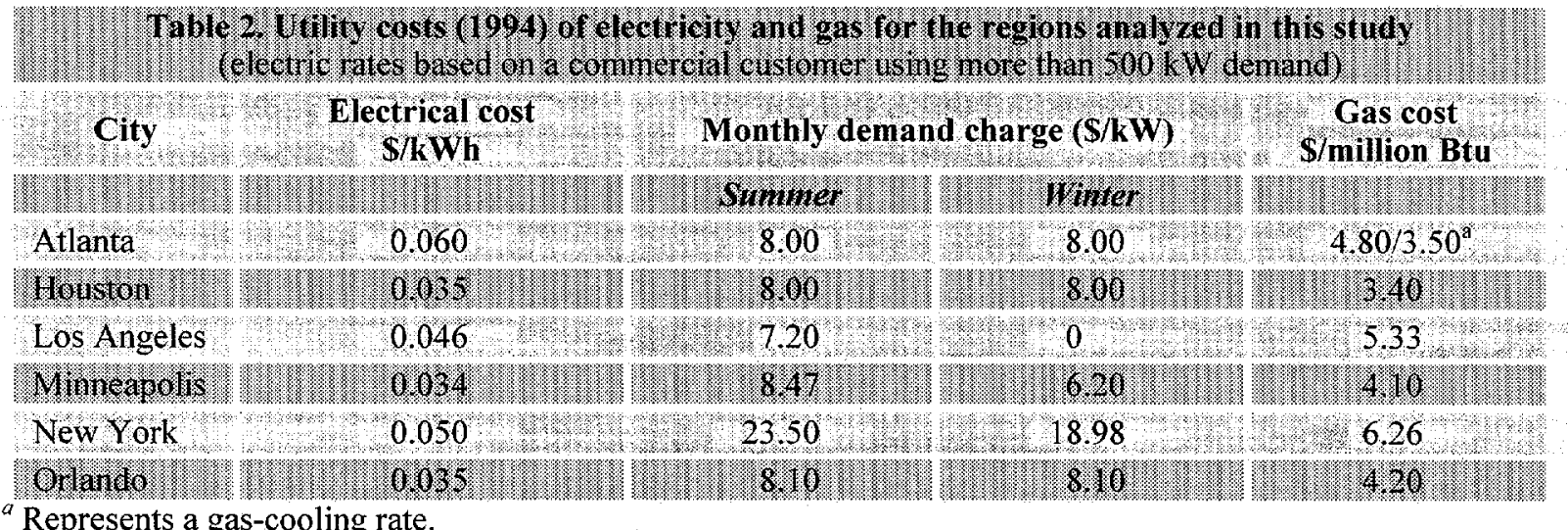

${ }^{a}$ Represents a gas-cooling rate.

In the Conclusions (Sect. 4), energy savings for each approach are combined with the projected market potential to provide an estimate of the overall energy reduction for the United States if SOAHU systems were to be applied to only a portion of new construction and renovation projects annually. 


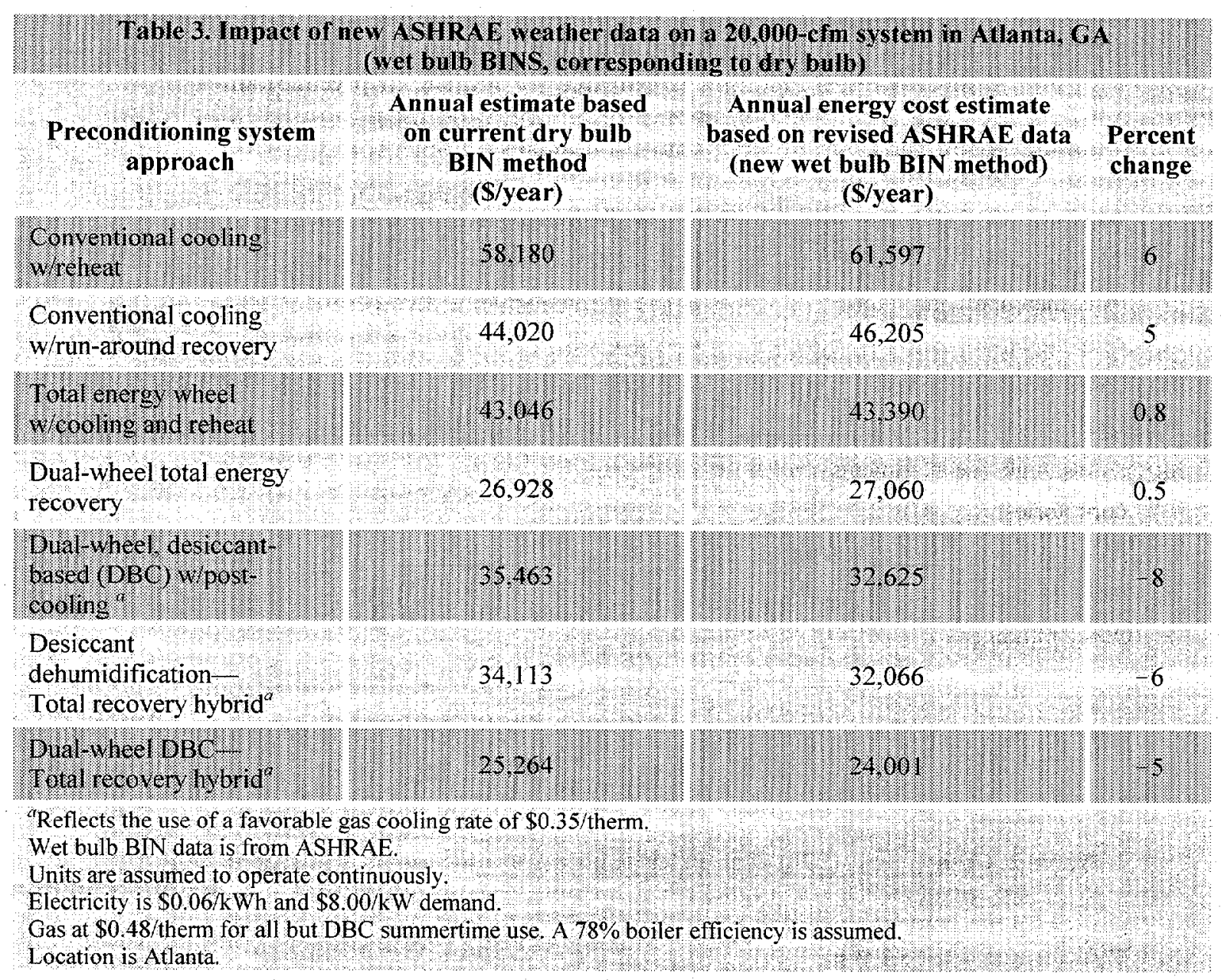

\subsection{COST ANALYSES}

To compare the various SOAHU approaches, the relative cost differences must be known. Given that the conventional cooling equipment is already mass-produced, while DBC systems are still custom built, the current cost to the market for these technologies does not allow for a meaningful comparison. To do so, Table 4 was created using sales prices for commercially produced, centralstation air-handling units provided by one of the major HVAC manufacturers to project what the selling price to the market would be if all products were mass-produced. The cost of the chiller and cooling tower required for each preconditioning approach is shown enclosed in parentheses, and the total system cost (air handler + chiller + cooling tower) is shown in bold. Table 4 shows the cost for each approach at three airflow capacities and provides the approximate physical dimensions of the air handling unit in inches for each system.

Table 5 combines the energy analyses completed with the cost information provided by Table 4 to show the simple payback period if systems with various sizes were applied in Atlanta. 


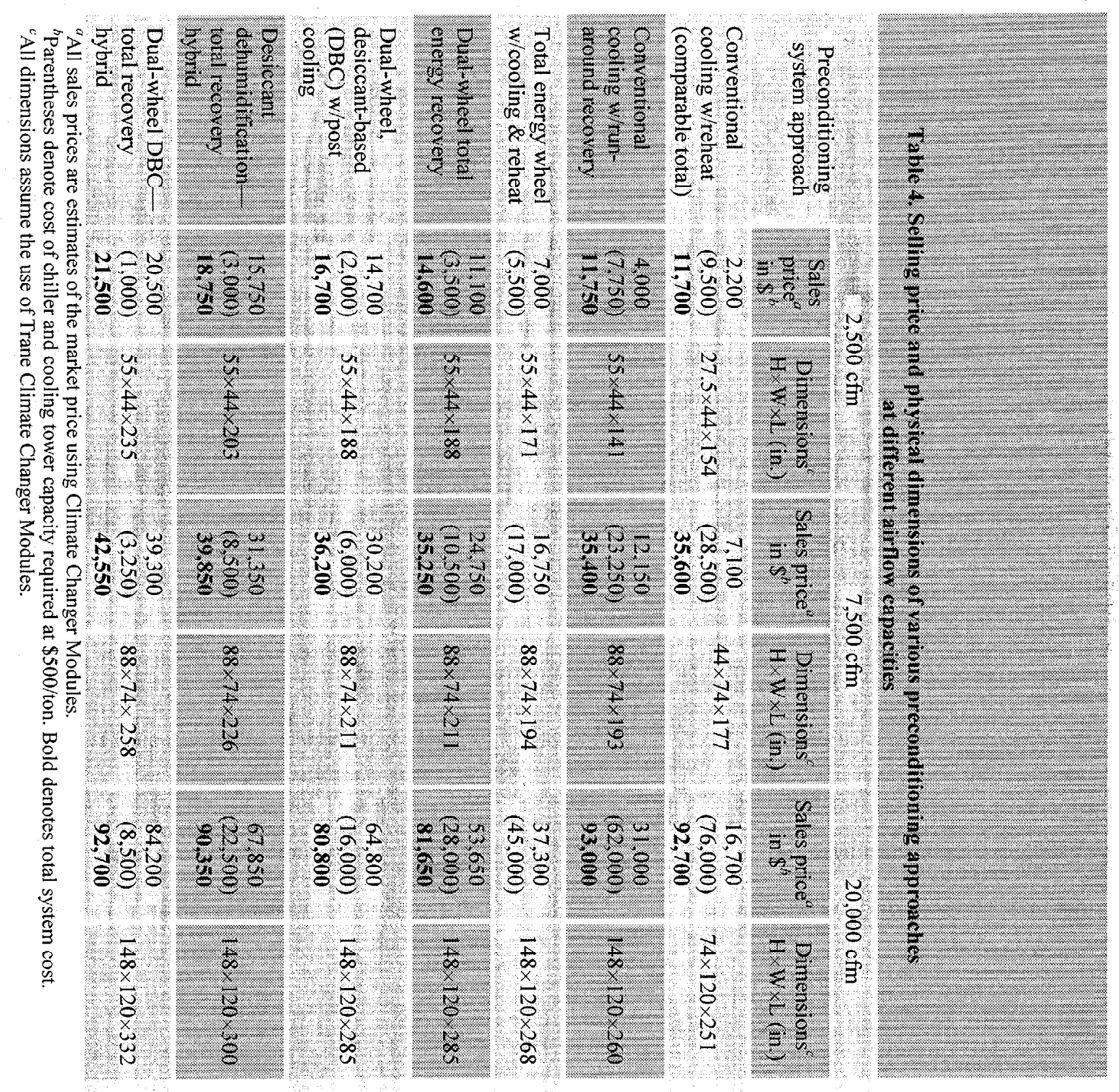




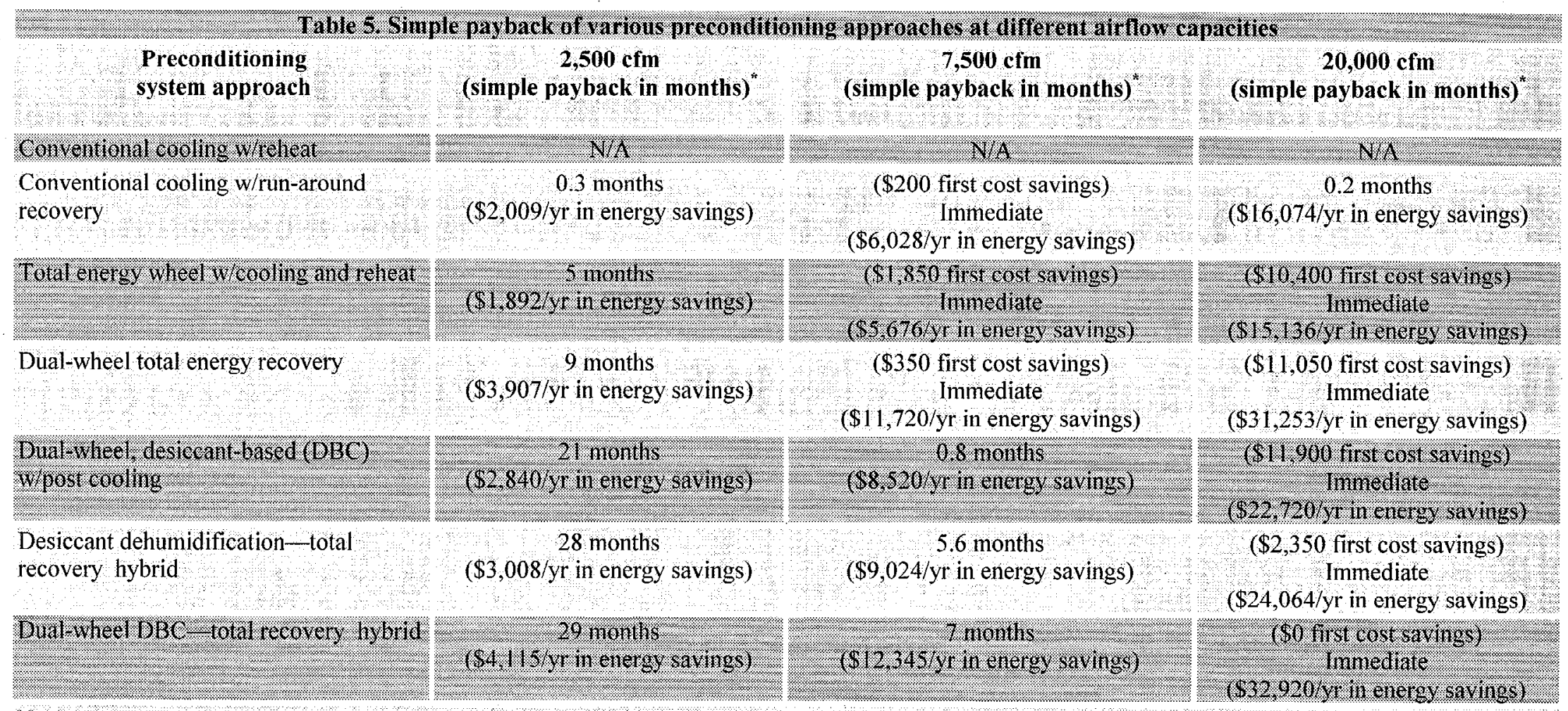

\section{Notes:}

"The simple payback compares the various preconditioning approaches with the conventional cooling with reheat approach

All dimensions assume the use of Trane Climate Changer Modules and SEMCO wheel modules

All sales prices are estimates of the market price using Climate Changer Modules

*The Atlanta weather data and 1994 local energy costs are used for this comparison

The energy savings are based on continuous operation

*The conventional cooling with run around uses the plate heat exchanger currently offered by Tranc. 


\section{RESUITS}

This investigation has provided a substantial amount of valuable information. The combination of the numerous energy analyses completed for the various SOAHU approaches, the equipment cost projections, the market size analyses, and the market survey conducted by SEMCO provide a fairly clear picture of where the opportunities for regenerated DBC systems exist.

\subsection{MODELING RESULTS}

The results of the modeling are summarized in Tables 3-5 (Sect. 2), by the Summary Sheets for Preconditioning Approaches in Appendix A, and by Cases 1-4 in Appendix C. The more important findings with respect to the market for regenerated desiccant systems include the following:

1. In general, if dry, space-neutral temperature air is desired (i.e., the basis of this investigation) and if an exhaust air path is available, the dual-wheel total-energy recovery (non-regenerated desiccant wheel) approach is by far the most desirable because it provides the highest energy savings. It is very cost-effective in that it also provides wintertime humidification.

2. If first cost is most important, and if maintaining humidity below $70 \%$ and above $20 \%$ is an acceptable design parameter, then desiccant preconditioning by single total-energy wheel (nonregenerated) is by far the most economical solution, provided there is access to an exhaust air path.

3. Where an exhaust air path is not accessible, the $\mathrm{DBC}$ approach may provide an attractive solution, depending on the hours of operation, demand charge, availability of waste energy or gas cost, and the importance of humidity control.

4. If a DBC system is to be applied to process humid outdoor air (120-140 grains) and supply it at 50-60 grains, the latent load is so significant that an oversized DBC system is required (very low face velocities across the wheels), making it a high-cost alternative. In such applications, combining total energy recovery with desiccant dehumidification makes sense.

5. If the $\mathrm{DBC}$ approach is used without access to a return air path, the energy savings projected by the sample modeling are significantly reduced because (1) the winter heat recovery is lost, and (2) more energy is required for regeneration because the inlet air contains a higher humidity content, and (3) the temperature entering the sensible wheel on the secondary side is much warmer, resulting in hotter air leaving the supply side of the system. Without access to the exhaust air path, the savings listed in this investigation for the $\mathrm{DBC}$ approach are reduced by approximately $50 \%$.

6. If weather data that more accurately reflect the humidity content of outdoor air (wet bulb BINs with corresponding mean coincident dry bulb temperatures) are used to complete energy analyses, compared with the dry bulb BINs used for most of this investigation, the energy consumption estimates for the conventional approach increase by approximately $6 \%$, the DBC energy consumption estimates decrease by approximately $10 \%$, and the total energy recovery estimates remain approximately the same (see Table 3 ).

7. The demand charges are a very significant portion of the cooling season energy savings for the $\mathrm{DBC}$ approach. The winter humidification savings are significant for the total energy recovery approach, especially in the cool, less-humid climates. 


\subsection{PAYBACK AND COST ANALYSES}

Table 4 (Sect. 2) summarizes the projected selling price for the various SOAHUs assuming they were built using mass-produced, pre-engineered air-handling units for commercial buildings.

Table 5 (Sect. 2) uses these costs and the energy cost analyses to project a simple payback based on chiller and cooling tower costs of $\$ 500 /$ ton. Some of the more important results from these analyses are these:

1. The small systems (2500-cfm) had payback periods ranging from 0.5 to 2.5 years, while the large systems had an immediate payback. This highlights one of the most important aspects of comparing air-side approaches, which is that the cost of the chillers required to solve ventilation air pretreatment problems is very high compared with the air-side solutions.

2. Size of the SOAIIU is a very important factor in the design process. All SOAHU systems were similar in size, except for the conventional cooling and reheat systems, which were significantly smaller (proving a significant advantage).

The $\$ 500 /$ ton figure was selected as a very "conservative" number. This number includes the chiller, the cooling tower, piping, insulation, and incremental installation costs. Clearly, increasing it slightly would decrease the payback period resulting from the use of active desiccant systems. Decreasing it would extend the payback periods of the active desiccant systems. The $\$ 500 /$ ton value was chosen in collaboration with Trane as a figure that would result in a fair analysis.

\subsection{SIZE OF POTENTIAL MARKET FOR SOAHUS}

Table 6 was prepared from information obtained from F. W. Dodge marketing forecasts (http://www.mag.fwdodge.com) for the year 1994. This table combines the information provided by ASHRAE standard 62-1989 with annual construction and renovation starts for the markets studied. The average size of each facility was taken from the DOE 1992 survey of Building Characteristics. Table 6 shows the potential market size for SOAHU systems by market and in total. The Final Market Analysis sheets provide these numbers based on evaluations made for each SOAHU approach for a given market. The percentage of the overall market potential listed for a given SOAHU approach is a subjective determination based on feedback from users and specifiers.

Appendix D provides a sample of the survey sheet used to weight the various market drivers. (The responses to the questions asked by the survey are summarized in Sect. 4 and tabulated in Tables 9 and 10 at the end of this section.) Factors such as importance of humidity control, first cost, energy efficiency, size of equipment, and required dew points from the SOAHU system helped in completing the subjective evaluation.

Appendix E includes nine "Final Market Segment Analysis" sheets. These sheets are used in the next section to summarize the opportunity for regenerated DBC approaches, as well as other approaches investigated for the various market segments. These sheets provide a brief summary of the benefits offered to the market by preconditioning, as well as a brief conclusion regarding the desiccant-based approaches investigated. Table 7 summarizes the information provided by the individual Final Market Segment Analysis sheets, showing the projected sales potential for each approach presented for each market.

The more important results from these analyses include the following: 


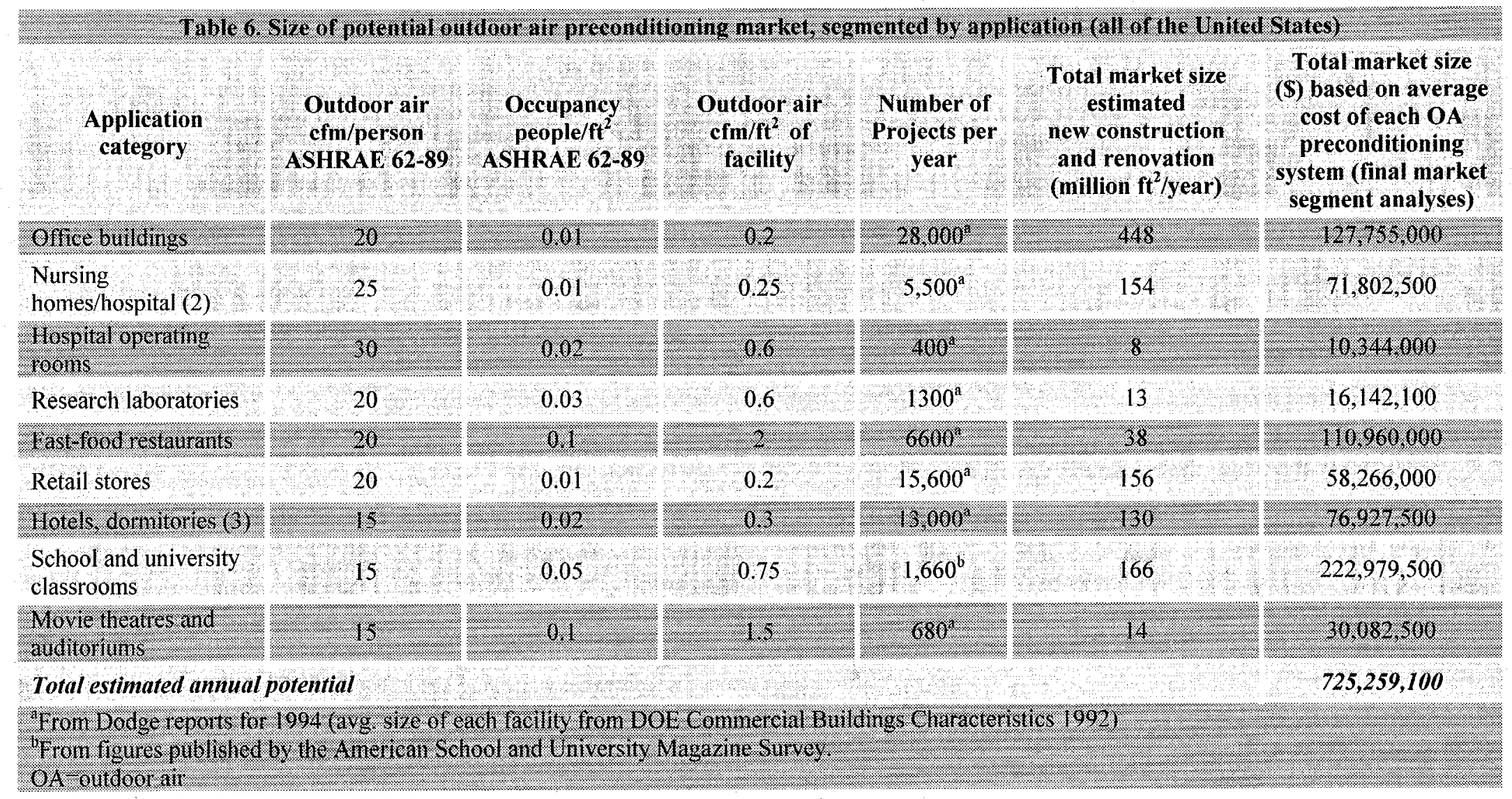




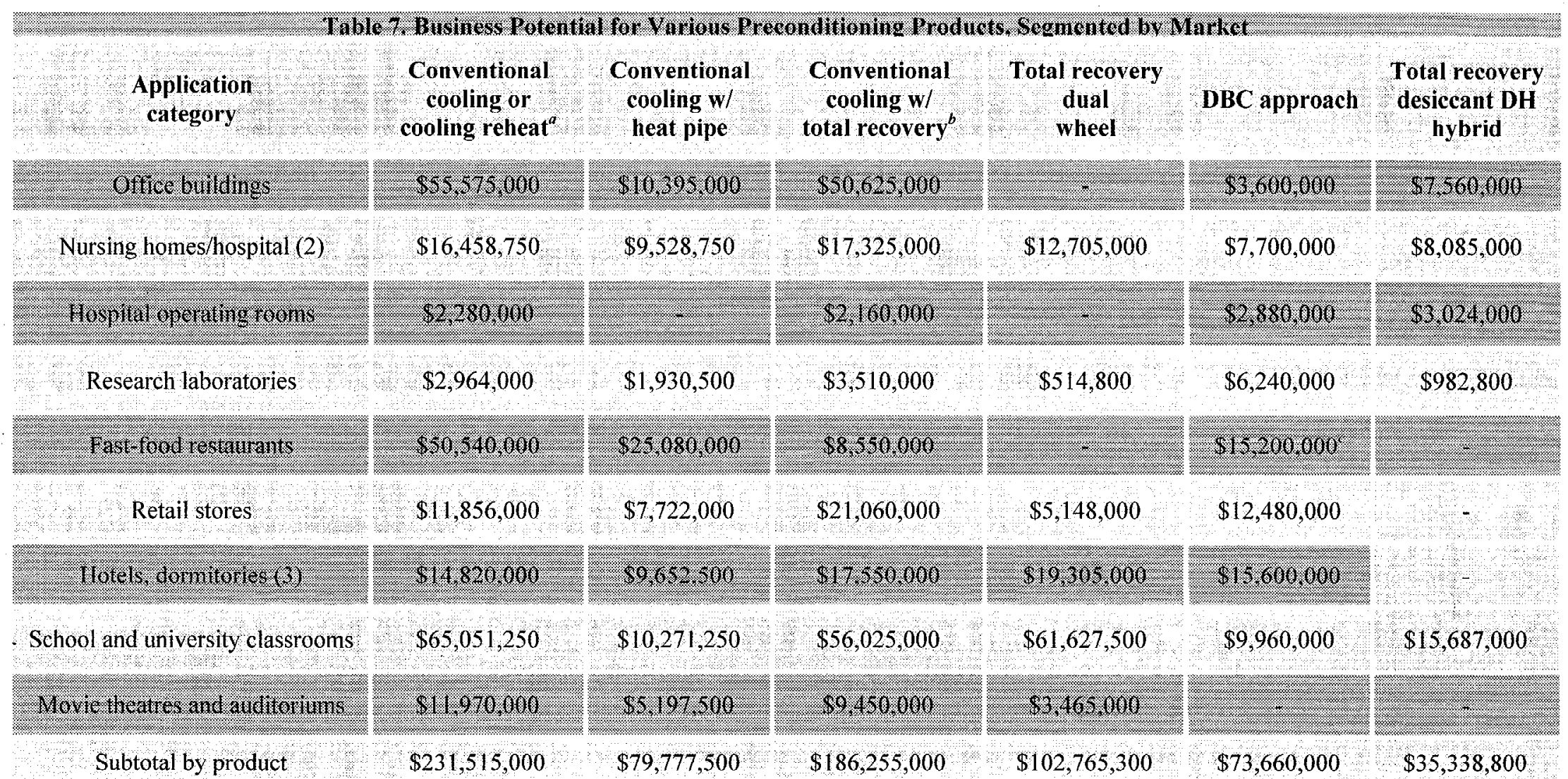

${ }^{a}$ The conventional approach includes both over-cooling reheat preconditioning of outdoor air treated by conventional HVAC units (no preconditioning)

${ }^{b}$ This section includes both total recovery with cooling/reheat and simple total energy recovery preconditioning to conventional systems

${ }^{\circ} \mathrm{DBC}$ approach for this market is likely contingent upon low cost, commercial product to augment packaged HVAC equipment 
1. The overall market potential for preconditioning outdoor air with SOAHUs is substantial (\$725,000,000 annually).

2. The largest market potential by far is the school market $(\$ 223,000,000 /$ year, $31 \%$ of total market potential).

3. Table 7 projects the potential sales volume by SOAHU approach and projects that the majority of the sales dollars will continue to go with conventional cooling approaches (with or without reheat). The next largest potentials are projected for single-wheel total energy recovery, dualwheel total energy recovery, conventional cooling with heat pipe, and $\mathrm{DBC}$, respectively.

4. The combined DBC and DBC hybrid market potential is estimated at approximately $\$ 109,000,000$ annually (15\% of total market opportunity).

\subsection{OVERALL ENERGY IMPACT ANALYSIS FOR SOAHUs}

Assuming that the Final Market Segment Analysis Sheets (Appendix E) accuratcly reflect the breakdown of SOAHU utilization by market; and assuming that ASHRAE 62-1989 is followed in the future; and, for simplicity, assuming that all SOAHUs are operated continuously, their use, compared with conventional over-cooling and reheat approaches, could reduce overall energy usage by 0.032 quads $\left(32 \times 10^{12} \mathrm{Btu}\right)$ annually (Table 8$)$. This figure is only for new construction and renovation projects on an annual basis. It also reflects the use of a SOAHU approach other than conventional cooling in approximately $48 \%$ of these buildings.

\subsection{SURVEY RESULTS}

A significant amount of data was collected as part of the survey. The results are summarized in Tables 9 and 10. The more important findings with respect to the markets for regenerated desiccant systems include the following:

1. The vast majority of the respondents listed first cost as most important for almost all markets. Energy efficiency was always listed last. (This would agree with the percentage of highefficiency equipment sold by the major HVAC suppliers).

2. Only one market, hospital operating rooms, needed supply air dew points that were lower than could be accomplished with a conventional cooling coil.

3. DX equipment is the most often used in all markets except nursing homes, hospitals, and research laboratories. Most respondents are aware that maintaining the desired indoor humidity levels with conventional DX systems processing a significant amount of outdoor air is not possible in many markets and locations.

4. In most cases, the respondents thought that space humidity levels needed to be controlled to a maximum of $70 \%$ and a minimum of $20 \%$, and that there are benefits to be recognized by controlling the humidity in the occupied spaces. Most felt that the conditions would preferably range between $60 \%$ and $30 \%$, but few felt that the market would pay a significant premium to maintain this range.

5. In all cases but fast-food restaurants and research laboratories, access to air to be used for recovery or the secondary side of a DBC system was available at least $50 \%$ of the time. 
Table 8. Annual estimated energy savings projected for the preconditioning approaches analyzed (new construction and renovations, assumes continuous operation, reflects results of final market segment analysis, uses Atlanta weather data and energy costs)

\begin{tabular}{|c|c|c|c|c|}
\hline $\begin{array}{c}\text { Preconditioning system } \\
\text { approach }\end{array}$ & $\begin{array}{c}\text { Outdoor air } \\
\text { CFM } \\
\text { preconditioned, } \\
\text { estimate of total } \\
\text { market }\end{array}$ & $\begin{array}{c}\text { Energy } \\
\text { savings/CFM, } \\
\text { excluding } \\
\text { demand }^{a}\end{array}$ & $\begin{array}{l}\text { Energy savings, } \\
\text { all markets } \\
\text { combined } \\
\text { (\$/year) }\end{array}$ & $\begin{array}{l}\text { Energy savings, } \\
\text { all markets } \\
\text { combined } \\
\text { (Million } \\
\text { BTU/year) }\end{array}$ \\
\hline $\begin{array}{l}\text { Conventional cooling } w / \\
\text { run around recovery }\end{array}$ & $48,350,000$ & $\$ 0.73$ & $\$ 35,295,500$ & $7,059,100$ \\
\hline $\begin{array}{l}\text { Total encrgy wheel w/ } \\
\text { cooling \& reheat }{ }^{b}\end{array}$ & $82,780,000$ & $\$ 0.67$ & $\$ 55,462,600$ & $11,092,520$ \\
\hline $\begin{array}{l}\text { Dual wheel total energy } \\
\text { recovery }\end{array}$ & $31,141,000$ & $\$ 1.43$ & $\$ 44,531,630$ & $8,906,326$ \\
\hline $\begin{array}{l}\text { Dual wheel desiccant } \\
\text { based (DBC) }\end{array}$ & $18,415,000$ & $\$ 0.95$ & $\$ 17,494,250$ & $3,498,850$ \\
\hline \multirow{3}{*}{$\begin{array}{l}\text { Desiccant } \\
\text { dehumidification-total } \\
\text { recovery hybrid }\end{array}$} & $8,413,800$ & $\$ 0.74$ & $\$ 6,226,212$ & $1,245,242$ \\
\hline & & & $\$ 159,010,192$ & $31,802,038$ \\
\hline & & Annual total & $\begin{array}{l}\text { (with demand } \\
\text { savings: } \\
\$ 190,000,000 \text { ) }\end{array}$ & $\begin{array}{c}0.032 \text { quadrillion } \\
\text { BTU/year }\end{array}$ \\
\hline \multicolumn{5}{|c|}{$\begin{array}{l}\text { "Savings estimate use Atlanta DB bin data, assume continuous supply of outdoor air, and only new } \\
\text { construction/renovation projects for } 1995 \text { projected by "Final Market Segment Analysis" are considered. } \\
\text { bhe cost of operating this system is compared against a conventional over-cooling/reheat system conditioning } \\
\text { outdoor air to } 65 \text { degrees } / 50 \text { grains during the cooling season and } 65 \text { degrees and } 35 \text { grains during the heating } \\
\text { season. } \\
\text { cThe cost of operating this system is compared against a conventional cooling system without reheat conditioning } \\
\text { outdoor air to } 51 \text { degrees } / 50 \text { grains during the cooling season and } 65 \text { degrees and } 35 \text { grains during the heating } \\
\text { season. }\end{array}$} \\
\hline
\end{tabular}




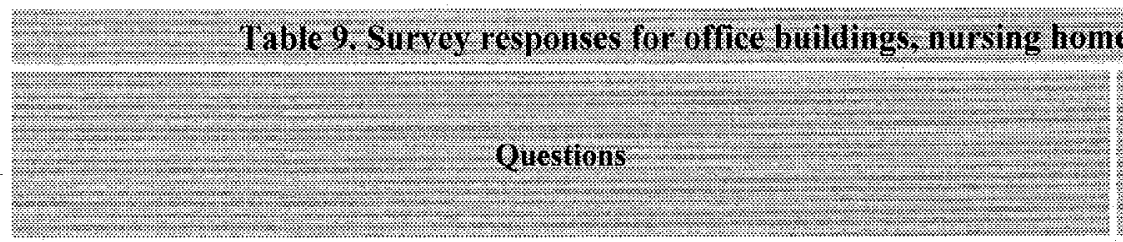

How important is humidity control for the application?

?
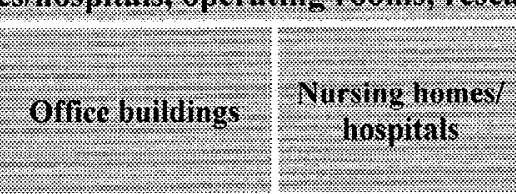

operating roonis ?

Restrartit.

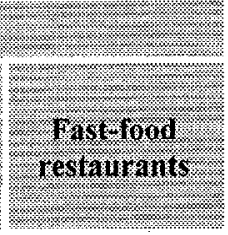

What minimum space relative humidity is acceptable?

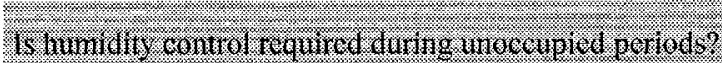

Not very

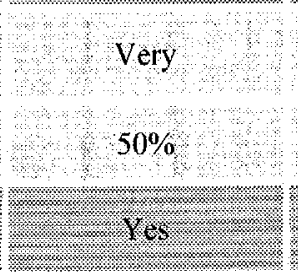

What percentage of total system airflow is outdoor air?

No minimum ? $30 \%$

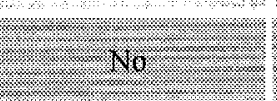

$0-20 \%$

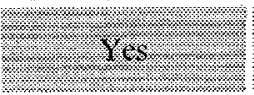

$30-50 \%$

More than $50 \%$

Very

Not very

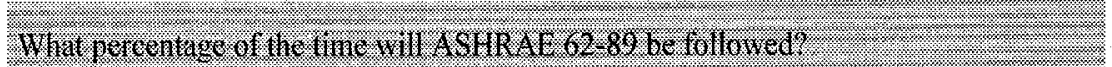

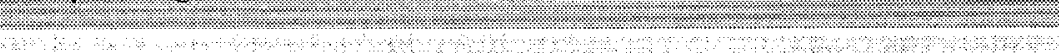

What type of AC equipment is most often used?

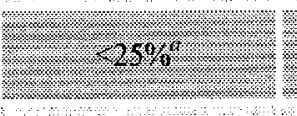

$-15 \%$

. $=75 \% 0$.

(.) $30 \%$ No minimum

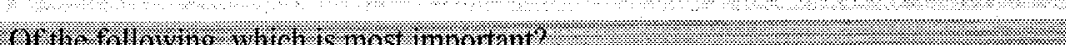
DX
Chilled water

Chilled water

Chilled water

More than $50 \%$

No:

$30-50 \%$

First cost

Energetficrenc.

Environmental control

Project \% with access to exhaust/return relief air?

\section{$\checkmark$}

.

(2).

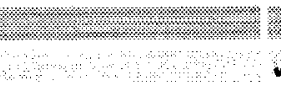

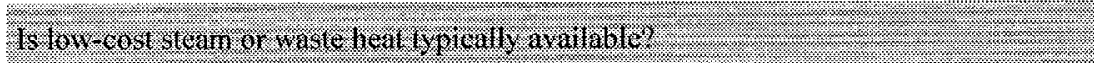

$25-50$

$\checkmark$

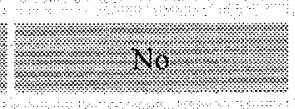

$50-75$

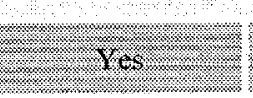

Yes

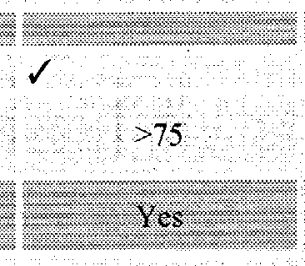

Yes $\checkmark$

$25-50$ \& 25

Are significant benefits gained by controlling humidity?

Somewhat

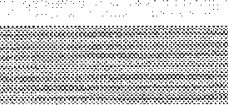

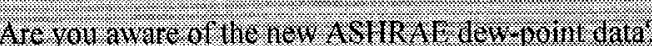

Is removing pollutants from the outdoor air important?

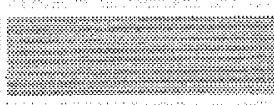

Somewhat

Somewhat

. 198.

:

Yes

Somewhat

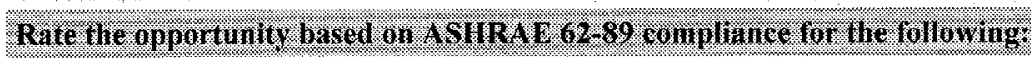

No
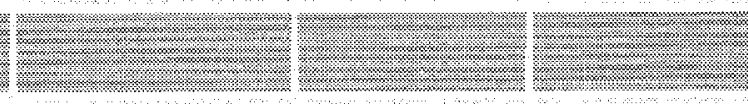

Desiccant dehumidification or DBC

..

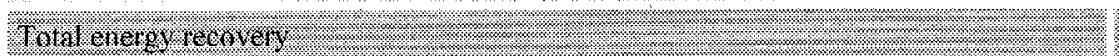

1

3

Yes

$\mathrm{No}$

Over-cool reheat

a $75 \%$ of the offices designed by engineers were reported to be designed in accordance with ASHRAE $62-89$, few built by "design build contractors" meet the standard.

$1=$ poor, 2 fair, $3=$ good

Provided low-cost commercial prodict available to this cost-conscious market. 
Table 10. Simvey responses for retail stores, hotels/dormilorles, classrooms, and theaters/auditorium

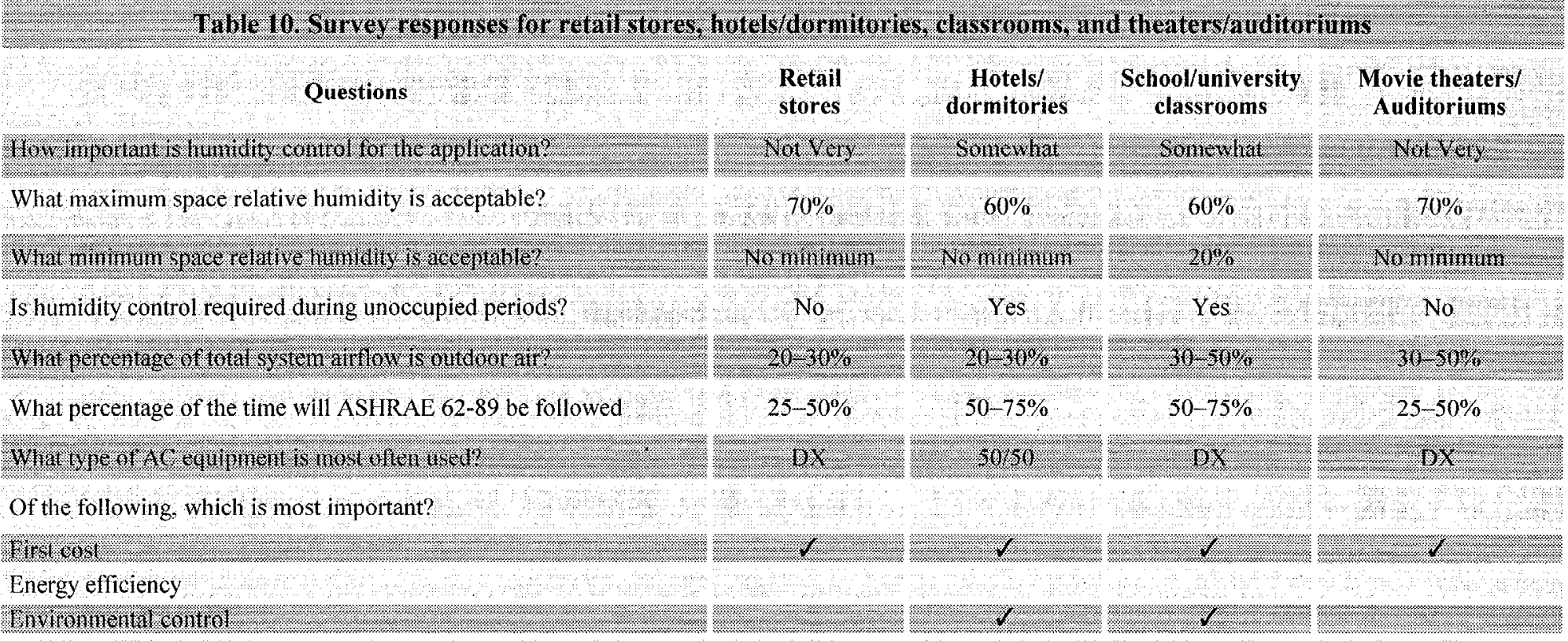

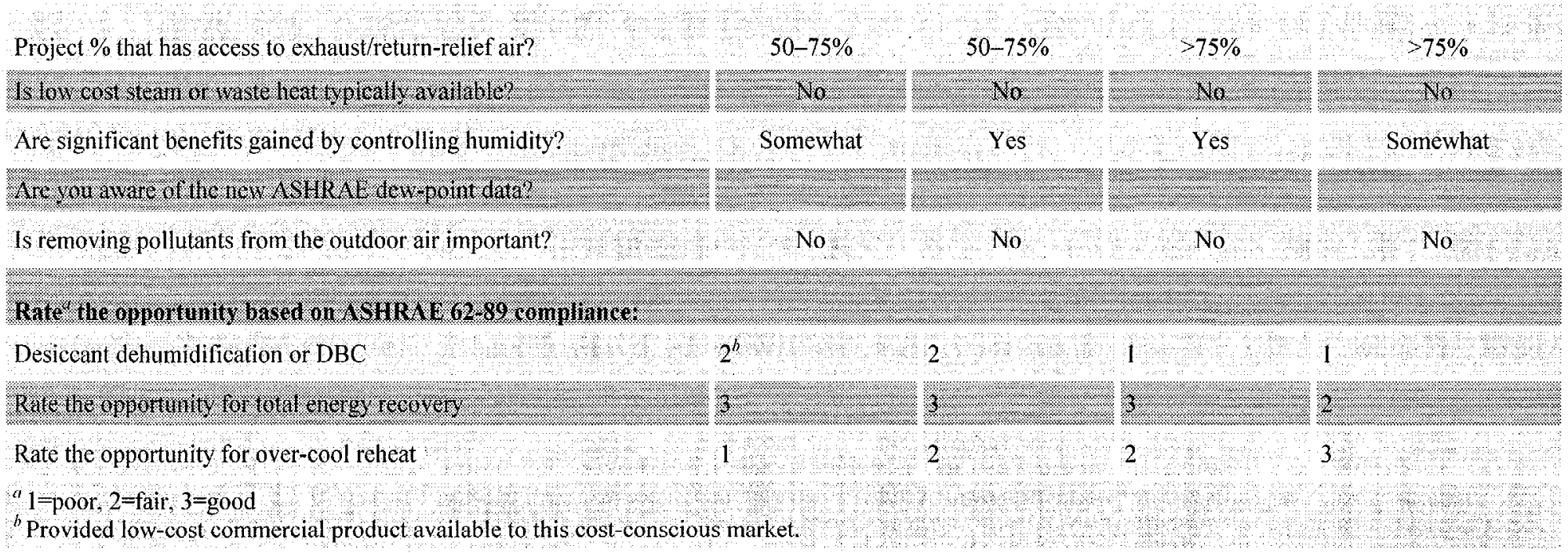




\section{CONCLUSIONS}

A number of important conclusions can be drawn as a result of this broad, first-phase market evaluation. The more important conclusions include the following:

1. A very significant market opportunity will exist for SOAHUs as more construction and renovation projects are designed to incorporate the recommendations made by the ASHRAE 62-1989 standard. Based on this investigation, the total potential market is currently $\$ 725,000,000$ annually (see Table 6, Sect. 3 ). Based on the market evaluations completed, it is estimated that approximately $\$ 398,000,000(55 \%)$ of this total market could be served by DBC systems if they were made cost-effective through mass production.

$\Lambda$ pproximately $\$ 306,000,000(42 \%)$ of the total can be served by a non-regenerated, desiccantbased total recovery approach, based on the information provided by this investigation. Approximately $\$ 92,000,000(13 \%)$ can be served by a regenerated desiccant-based cooling approach (see Table 7, Sect. 3).

2. A projection of the market selling price of various desiccant-based SOAHU systems was prepared using prices provided by Trane for central-station, air-handling modules currently manufactured. The wheel-component pricing was added to these components by SEMCO. This resulted in projected pricing for these systems that is significantly less than that currently offered by custom suppliers (see Table 4, Sect. 2). Estimated payback periods for all SOAHU approaches were quite short when compared with conventional over-cooling and reheat systems. Actual paybacks may vary significantly depending on site-specific considerations.

3. In comparing cost vs benefit of each SOAHU approach, it is critical that the total system design be evaluated. For example, the cost premium of a DBC system is very significant when compared to a conventional air handling system, yet the reduced chiller, boiler, cooling tower, and other expense often equals or exceeds this premium, resulting in a rapid payback period while providing significant energy savings (see Table 5 , Sect. 2 ).

4. The survey conducted as part of this investigation provided several key positions that impact the likely use of one SOAHU approach vs another. The more important ones included these:

- Most projects are designed using DX systems and the agreement by most interviewed that such systems cannot control humidity while processing the continuous outdoor air quantities required by the ASHRAE IAQ standard provides the single most significant market driver for using a SOAHU approach.

- First cost was almost always viewed as more important that energy efficiency and environmental conditions by those surveyed.

- There is a wide difference in opinion regarding the need to control humidity in spaces when they are unoccupied, and regarding the level at which the space humidity needs to be controlled during both occupied and unoccupied modes.

- Currently, little value is placed on the ability to maintain a dry cooling coil.

- Wintertime humidification, provided by the desiccant-based recovery wheel, is considered a significant benefit.

- With the exception of fast-food restaurants and research laboratories, an exhaust air path can be made available for recovery or for the secondary side of a DBC system. 
5. The most promising opportunities for regenerated desiccant approaches based on market need were determined to be hospital operating rooms, nursing homes and hospitals, and research laboratories. These markets offer approximately $\$ 29,000,000$ annually in sales potential for DBC and $\mathrm{DBC}$ /total energy recovery hybrid systems.

The hospital operating room market was determined to be the only market investigated that required a dew point below that obtainable with conventional chilled water cooling coils. Nursing homes, hospital bed areas, and research laboratories share the advantage of being less sensitive to project first cost, requiring continuous operation of the outdoor air systems, having a need for humidity control, showing interest in operating dry cooling coils, often having access to low-cost steam for regeneration, and needing features offered only by non-unitary equipment.

To effectively serve these markets, an institutional grade SO $\mathrm{HU}$ needs to be offered. It would include dual wall construction, high-efficiency filtration, backward-curve airfoil fans, good access for maintenance, options for a variety of coils and humidificrs, and controls designed to work with industry standards.

6. The most promising opportunities for regenerated desiccant approaches based on annual sales potential were determined to be hotels and dormitories, retail stores, and school facilities. These markets offer approximately $\$ 53,727,000$ annually in sales potential for DBC and DBC/total energy recovery hybrid systems.

The potential for regenerated desiccant systems in retail stores reflects the conditioning of outdoor air to stores that combine food sales and retail, in addition to a portion of large retail facilities using gas-engine cooling in high-demand cost areas. Such facilities as supermarkets and ice rinks have proven offer a significant market potential to desiccant dehumidification systems, yet since they process recirculated air and benefit from the refrigeration loads (ice rinks or freezer loads) and not loads associated with outdoor air or the interior space conditions, these markets were not included in this investigation. (If they were, it is projected that they could add an additional $\$ 15$ to $\$ 25$ million annually to the regenerated desiccant-based SOAHU approaches).

The potential for regenerated desiccant systems in hotels/dormitories reflects the conditioning of outdoor air to these facilities, most likely the corridors, to control humidity in order to avoid moisture problems. The hotel industry has established that humidity problems result in very significant replacement and maintenance costs each year. The regenerated desiccant systems would likely be used where access to an exhaust air path is limited.

The comparison of outdoor air preconditioning systems shows that passive desiccant systems clearly provide the highest energy savings and lowest first cost. This is a result of the consistent availability of a cool, dry exhaust air path that is perfect for the "total recovery" option. Also, schools need to process large quantities of ventilation air at very high outdoor-air humidity levels (130 grains), dehumidify it, typically to 50 to 55 grains, and provide it to the conditioned space at 65 to $70^{\circ}$. This perfectly fits the capability of the passive-desiccant, dual-wheel system. The active system cannot provide this 75 - to 80 -grain reduction in a single pass across an active wheel. In addition, the air supplied would be very warm and would require significant postcooling.

Therefore, the market opportunity for active desiccant systems in schools is limited to "advanced system designs" using waste heat, engine chillers, ice systems, or areas where electrical demand charges are extremely high. In these applications, where designers feel that there is a benefit provided by operating a dry coil, the active systems may also find acceptance despite the significant first-cost premium. 
These markets are far more cost-sensitive than the hospital, nursing home, and research facility markets mentioned earlier. Although the benefits of the technology would allow a percentage of these markets to be served by the same institutional-grade products required by facilities such as hospitals and nursing homes, the construction of the equipment for these markets would have to be more of a unitary, rooftop design in order to gain maximum market penetration.

7. Fast-food restaurants offer a significant potential for regenerated desiccant systems. The kitchen exhaust creates a need for makeup air. The loads within the space are variable and often result in high latent-to-sensible ratios. The hours of operation are high, and gas is always available. However, since these markets are very much driven by first cost, market acceptance will likely depend on a low-cost, commercial-grade product that could be easily coupled with the packaged HVAC units currently used.

8. The investigation concluded that if an exhaust air path is available, the non-regenerated desiccant total recovery approach will almost always be the SOAHU of choice. It typically provides more energy savings at a lower cost than regenerated desiccant systems. It is often more capable of handling the extreme humidity conditions encountered by some environments ( 120 to 150 grains). It provides winter humidification that makes it a year-round device applicable to most climates. It allows customers and engineers to continue using familiar conventional cooling technologies. It also eliminates the need for evaporative coolers, viewed as a maintenance item and a potential contributor to poor indoor air quality.

For applications where careful humidity control is not a requirement (most markets), unitary systems can usually be coupled with a single-wheel, non-regenerated, desiccant-based total energy recovery preconditioning systems to meet the needs of the application.

9. Energy analyses completed using weather data that more accurately reflect outdoor air humidity content show the cost of operating conventional cooling systems to be approximately $6 \%$ higher than estimates using the traditional dry bulb BIN information. Total energy recovery system operating costs remained approximately the same, while those of regenerated desiccant systems are reduced by approximately $10 \%$ (assuming that there is an exhaust air path available for the secondary side of the system) (Table 5, Sect. 2).

10. A very significant amount of energy would be saved in the United States annually should the SOAHU projections made by this investigation occur. Assuming that the systems are operated $50 \%$ of the time on average for all markets, a reduction of 0.016 quads per year would be expected ( 0.032 quadrillion Btu/year if operated continuously). This is projected energy consumption savings compared with using conventional cooling and conventional cooling/reheat systems, using steam heat for the heating mode.

Based on the information resulting from this investigation, the most attractive markets are the following:

- Nursing homes

- Hospitals (patient areas and operating rooms)

- Hotels/dormitories

- School and university classrooms

The estimated sales opportunity for active desiccant systems at full market penetration, based upon the market investigation, amounts to approximately $\$ 63,000,000$ annually for the four market segments identified. This business potential appears large enough to merit a serious consideration of technology integration by the major HVAC manufacturers: 



\section{INTERNAL DISTRIBUTION}
1. J. E. Christian
2. G. E. Courville
3. T. R. Curlee
4. R. C. Devault
5. P. D. Fairchild
6. M. A. Karnitz
7. C. I. Moser

\author{
8-29. J. R. Sand \\ 30. A. Schaffhauser \\ 31. R. B. Shelton \\ 32. E. A. Vineyard \\ 33. Laboratory Records-RC \\ 34. Central Research Library \\ 35-36. OSTI
}

\section{EXTERNAL DISTRIBUTION}

37. Lilia A. Abron, PEER Consultants, 1460 Gulf Blvd., Apt. 1103, Clearwater, FL 33767

38. Joel Anderson, Mississippi Valley Gas Company, P.O. Box 3348, Jackson, MS 39207

39. Ren Anderson, National Renewable Energy Laboratory, 1617 Cole Blvd., Golden, CO 804013393

40. Frank Ballistreri, Reliant Energy-Minnegasco, P.O. Box 59038, 15th Floor, 800 LaSalle Ave., Minneapolis, MN 55459-0038

41. Douglas Bauer, Commission on Engineering and Technical Systems, National Research Council, Harris 280, 2001 Wisconsin Ave. NW, Washington, D.C., 20007

42. John C. Brady, Mechanical Engineering, ATS\&R, 8501 Golden Valley Rd., \#300, Minneapolis, MN 55427

43. Paul L. Brillhart, University of Illinois-Chicago, Energy Resources Center, 1223 SEO, 842 West Taylor St., Chicago, IL 60607-7022

44. Thom Clemens, Desicair Sales Manager, ATS, 1572 Tilco Dr., Fredrick, MD 21701

45. Susan L. Cutter, Hazards Research Laboratory, Department of Geography, University of South Carolina, Columbia, SC 20208

46. John Fischer, SEMCO, Inc., 737 Terrell Crossing, Marietta, GA 30067

47. R. Fiskum, U.S. Department of Energy, EE-42, 5E-036/Forrestal, Washington, D.C. 20585

48. P. W. Garland, UT-Battelle, LLC, 901 D St. SW, Suite 900, Washington, D.C. 20024

49. Arthur D. Hallstrom, Air Handling Systems, The Trane Company, 1500 Mercer Rd., Lexington, KY 40511

50. Lew Harriman, Mason-Grant Consulting, P.O. Box 6547, 57 South St., Portsmouth, NH 03802

51. Stephen G. Hildenbrand, Environmental Sciences Division, Oak Ridge National Laboratory, P.O. Box 2008, Oak Ridge, TN 37831-6037

52. Keith Hodge, Department of Mechanical Engineering, 210 Carpenter Engineering Bldg., P.O. Drawer ME, Mississippi State, MS 39762-5925

53. John Kelly, IGT, 1700 S. Mount Prospect Rd., Des Plaines, IL 60018-1804

54. Douglas R. Kosar, Gas Rescarch Institute, 8600 West Bryn Mawr Ave., Chicago, IL 60631 3562

55. Tony Occhionero, American Gas Cooling Center, 400 N. Capitol St., NW, Washington, D.C. 20001

56. P. Richard Rittelmann, Burt Hill Kosar Rittelmann Associates, 400 -Morgan Center, Butler, PA 16001-5977

57. Mike Schell, Telaire, 6489 Calle Reale, Goleta, CA 93117

58. David Simkins, Munters Corporation, P.O. Box 640, Amesbury, MA 01913

59. Steven Slayzak, Center for Buildings and Thermal Systems, National Renewable Energy Laboratory, 1617 Cole Blvd., Golden, CO 80401-3393 
60. Richard S. Sweetser, EXERGY Partners Corp., 12020 Meadowville Court, Herndon, VA 20170

61. C. Michael Walton, Department of Civil Engineering, University of Texas at Austin, Austin, TX 78712-1076

62. William M. Worek, University of Illinois-Chicago, Fnergy Resources Center, $851 \mathrm{~S}$. Morgan St., 1207 SEO, Chicago, IL 60607-7054

63. Jaroslav Wurm, Director of Space Conditioning Research, IGT, 1700 S. Mount Prospect Rd., Des Plaines, IL 60018-1804 


\section{APPENDIX A}

\section{SAMPLE ENERGY BIN ANALYSIS SHEETS}

FOR EACH SOAHU APPROACH 



\section{Summary Sheet for Preconditioning Approach 1: Conventional Cooling with Reheat}

ORNL 99-06759/gss

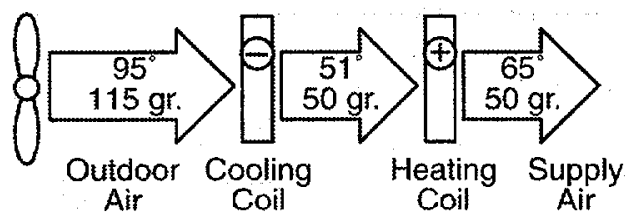

This approach uses conventional cooling, either chilled water or DX to overcool the outdoor air to remove humidity. Reheat is applied via hot water, heat of rejection from a condenser coil, hot gas with fan heal, steam or electric reheat (if allowed by the local energy code).

Approach 1. Conventional cooling with reheat.

\begin{tabular}{|c|c|c|c|}
\hline \multirow{2}{*}{$\begin{array}{c}\text { Preconditioning Approach } \\
\text { Analysis Summary }\end{array}$} & \multicolumn{3}{|c|}{ System CFM (Nominal) } \\
\hline & 2500 & 7500 & 20000 \\
\hline $\begin{array}{l}\text { Conventional cooling tons at design* } \\
\text { Electrical demand at design* (KW) } \\
\text { Reheat energy at design* (BTU) }\end{array}$ & $\begin{array}{c}19 \text { tons } \\
25 \\
48462 \\
\end{array}$ & $\begin{array}{c}57 \text { tons } \\
75 \\
145384 \\
\end{array}$ & $\begin{array}{l}152 \text { tons } \\
200 \\
387692 \\
\end{array}$ \\
\hline $\begin{array}{r}\text { Annual encrgy consumption** } \\
\text { Atlanta (DB BIN/New WB BIN) } \\
\text { Houston } \\
\text { Los Angeles } \\
\text { Minneapolis } \\
\text { New York } \\
\text { Orlando }\end{array}$ & $\begin{array}{c}\$ 7,272 / \$ 8,000 \\
\$ 6150 \\
\$ 3169 \\
\$ 5640 \\
\$ 8988 \\
\$ 6610\end{array}$ & $\begin{array}{c}\$ 21,818 / \$ 23,099 \\
\$ 18450 \\
\$ 9507 \\
\$ 16920 \\
\$ 26963 \\
\$ 19830\end{array}$ & $\begin{array}{c}\$ 58,180 / \$ 61,597 \\
\$ 49199 \\
\$ 25353 \\
\$ 45120 \\
\$ 71901 \\
\$ 52881\end{array}$ \\
\hline Dimensions & 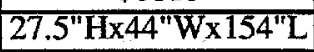 & $44^{\prime \prime} \times 74^{\prime \prime} \times 177^{\prime \prime}$ & $74^{11} \times 120^{11} \times 251^{11}$ \\
\hline Approximate sales price to market & $\$ 2200$ & $\$ 7100$ & $\$ 16700$ \\
\hline
\end{tabular}

\section{Key Benefits and Weaknesses:}

Benefits include compact design and low first cost. This approach does not require an exhaust air path.

Weaknesses include very high cost of operation and very poor operation with DX approach. No winter time recovery benefit. Concern for freezing the cooling coil or hot water reheat coil during winter operation. Very large chiller/DX condenser required in addition to large capacity for reheat, which must be factored into first cost evaluation.

* Design Based on outdoor air at $95 \mathrm{deg} / 115$ grains, supply outdoor air at 50 grains, 65-75 degree dry bulb ** Energy consumption based on continuous operation and local 1994 utility costs for commercial facility and adjusts for cooling tower, pumps \& parasitic fan energy assuming 1.5" of extemal static pressure, and includes cost of heating and humidifying supply air to 65 degrees and 35 grains during the heating scason 


\section{Summary Sheet for Preconditioning Approach 2: Conventional Cooling with Run-around Recovery}

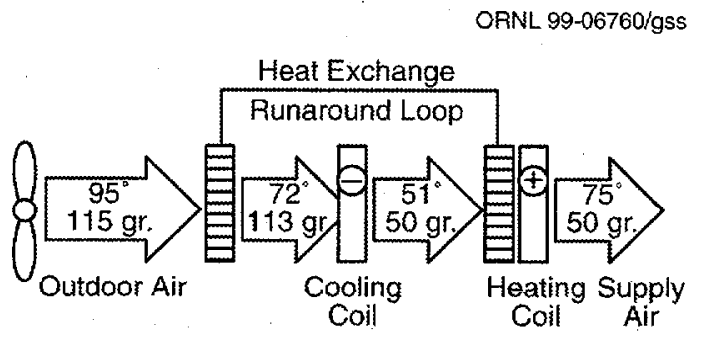

Approach 2. Conventional cooling with runaround recovery reheat.
This approach uses conventional cooling, either chilled water, or DX to overcool the outdoor air to remove humidity. Reheat is applied via the integration of a runaround coil, heat pipe, or plate exchanger and assisted, in some cases, with additional hot water, steam, or electric heat.

\begin{tabular}{|c|c|c|c|}
\hline \multirow{2}{*}{$\begin{array}{c}\text { Preconditioning Approach } \\
\text { Analysis Summary }\end{array}$} & \multicolumn{3}{|c|}{ System CFM (Nominal) } \\
\hline & 2500 & 7500 & $\mathbf{2 0 0 0 0}$ \\
\hline $\begin{array}{l}\text { Conventional cooling tons at design* } \\
\text { Electrical demand at design* (KW) } \\
\text { Reheal energy at design* (BTU) }\end{array}$ & $\begin{array}{c}\text { T5.5 tons } \\
21 \\
0\end{array}$ & $\begin{array}{c}46.5 \text { tons } \\
63 \\
0\end{array}$ & $\begin{array}{c}124 \text { tons } \\
169 \\
0\end{array}$ \\
\hline \begin{tabular}{|r|} 
Annual energy consumption \\
\\
Atlanta \\
Houston \\
Los Angeles \\
Minneapolis \\
New York \\
Orlando
\end{tabular} & $\begin{array}{l}\$ 5263 \\
\$ 4615 \\
\$ 2518 \\
\$ 5097 \\
\$ 6992 \\
\$ 3826\end{array}$ & $\begin{array}{l}\$ 15790 \\
\$ 13844 \\
\$ 7555 \\
\$ 15291 \\
\$ 20976 \\
\$ 11479\end{array}$ & $\begin{array}{l}\$ 42106 \\
\$ 36918 \\
\$ 20147 \\
\$ 40777 \\
\$ 55937 \\
\$ 30611\end{array}$ \\
\hline Dimensions & 55"Hx44"Wx141"L & $88^{n} \times 74^{\prime \prime} \times 193^{n}$ & $148^{11} \times 120^{\prime \prime} \times 260^{11}$ \\
\hline Approximate sales price to market & $\$ 4000$ & $\$ 12150$ & $\$ 31000$ \\
\hline
\end{tabular}

\section{Key Benefits and Weaknesses:}

Benefits include compact design (at lower airflows) and relatively low first cost. This approach does not require an exhaust air path. It is less energy consuming that a conventional over cooling with reheat system and it reduces the required cooling capacity (modestly) and reheating source (significantly).

Weaknesses include high pressure losses associated with two wet components. No winter time benefit to this approach despite the horsepower penalty year round. This often offsets much of the cooling season savings. The temperature leaving the unit is too cool on many overcast, humid days (ic: 72 degress and raining) so additional reheat is often required. This approach does not stabilize coil entering conditions well enough over various outdoor air conditions to allow $D X$ to be utilized effectively.

* Design Based on outdoor air at $95 \mathrm{deg} / 115$ grains, supply outdoor air at 50 grains, $65-75$ degree dry bulb ** Energy consumption based on continuous operation and local 1994 utility costs for commcrcial facility and adjusts for cooling tower, pumps \& parasitic fan energy assuming 1.5" of external static pressure, and includes cost of heating and humidifying supply air to 65 degrees and 35 grains during the heating season 


\section{Summary Sheet for Preconditioning Approach 3: Dessicant Total Energy Recovery with Cooling/Reheat}

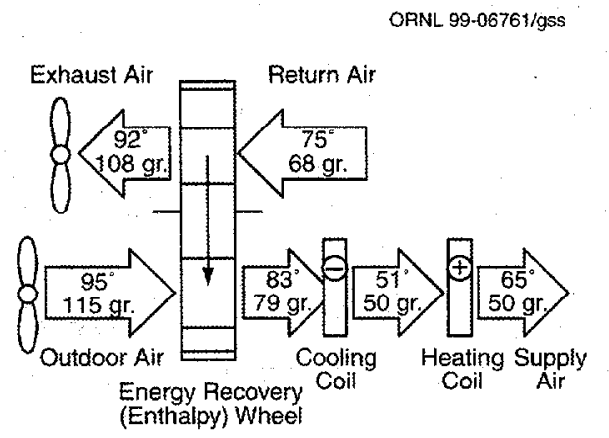

This approach uses a total energy wheel to precool and predehumidify the outdoor air delivered to a conventional cooling coil, either chilled water, or DX, to overcool the outdoor air to remove humidity. Reheat is applied via hot water, steam, or electric.

Approach 3. Total recovery and conventional cooling with reheat.

\begin{tabular}{|c|c|c|c|}
\hline \multirow{2}{*}{$\begin{array}{c}\text { Preconditioning Approach } \\
\text { Analysis Summary }\end{array}$} & \multicolumn{3}{|c|}{ System CFM (Nominal) } \\
\hline & 2500 & 7500 & 20000 \\
\hline $\begin{array}{l}\text { Conventional cooling tons at design* } \\
\text { Electrical demand at design* }(\mathrm{KW}) \\
\text { Reheat energy at design* (BTU) }\end{array}$ & $\begin{array}{c}11 \text { tons } \\
16 \\
48462\end{array}$ & $\begin{array}{c}34 \text { tons } \\
48 \\
145384\end{array}$ & $\begin{array}{l}90 \text { tons } \\
128 \\
387692\end{array}$ \\
\hline $\begin{array}{r}\text { Annual energy consumption } \\
\text { Atlanta } \\
\text { Houston } \\
\text { Los Angeles } \\
\text { Minneapolis } \\
\text { New York } \\
\text { Orlando }\end{array}$ & $\begin{array}{l}\$ 5381 \\
\$ 4891 \\
\$ 4226 \\
\$ 3151 \\
\$ 5217 \\
\$ 5202\end{array}$ & $\begin{array}{l}\$ 16142 \\
\$ 14673 \\
\$ 12678 \\
\$ 9452 \\
\$ 15651 \\
\$ 15605\end{array}$ & $\begin{array}{l}\$ 43046 \\
\$ 39127 \\
\$ 33808 \\
\$ 25205 \\
\$ 41735 \\
\$ 41614\end{array}$ \\
\hline Dimensions & $55^{\prime \prime H \times 44 " W \times 171 " L ~}$ & $88^{\prime \prime} \times 74^{\prime \prime} \times 194^{\prime \prime}$ & $148^{\prime \prime} \times 120^{\prime \prime} \times 268^{\prime \prime}$ \\
\hline Approximate sales price to market & $\$ 7015$ & $\$ 16783$ & $\$ 37275$ \\
\hline
\end{tabular}

\section{Key Benefits and Weaknesses}

Benefits include a significant reduction in operating cost over approach 1, as well as reduction in refrigeration tons required. The total energy wheel provides more consistent outdoor air conditions to the cooling coil making the use of DX more functional. The energy recovery wheel also provides very significant wintertime energy savings as well as free humidification. It protects the coils during winter operation. Peak demand is cut significantly.

Weaknesses include higher cost than option 1 and a larger size since it is an exhaust as well as supply unit. Biggest weakness is that it noeds an exhaust air volume to function.

* Design Based on outdoor air at 95 deg/115 grains, supply outdoor air at 50 grains, $65-75$ degrce dry bulb ** Encrgy consumption based on continuous operation and local 1994 utility costs for commercial facility and adjusts for cooling tower, pumps \& parasitic fan energy assuming $1.5^{\prime \prime}$ of external static pressure, and includes cost of heating and humidifying supply air to 65 degrees and 35 grains during the heating season 


\section{Summary Sheet for Preconditioning Approach 4: Dual-Wheel Total Energy Recovery}

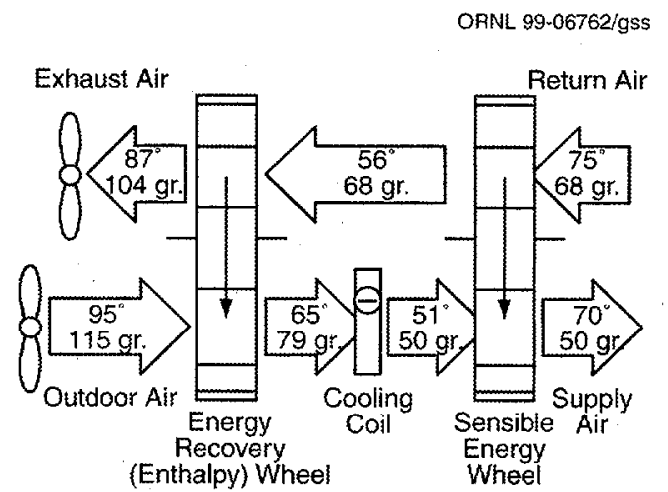

This approach uses two energy recovery wheels, one sensible and onc latent, and a cooling coil to provide the same conditions as approach 3 , except the sensible wheel provides free reheat and provides precooled air to to the return side of the total wheel, significantly reducing the required conventional cooling capacity.

Approach 4. Dual wheel total recovery configuration.

\begin{tabular}{|c|c|c|c|}
\hline \multirow{2}{*}{$\begin{array}{c}\text { Preconditioning Approach } \\
\text { Analysis Summary }\end{array}$} & \multicolumn{3}{|c|}{ System CFM (Nominal) } \\
\hline & 2500 & 7500 & 20000 \\
\hline $\begin{array}{l}\text { Conventional cooling tons at design* } \\
\text { Electrical demand at design* (KW) } \\
\text { Reheat encrgy at design* (BTU) }\end{array}$ & $\begin{array}{l}7 \text { tons } \\
11 \\
0\end{array}$ & $\begin{array}{c}21 \text { tons } \\
33 \\
0\end{array}$ & $\begin{array}{c}56 \text { tons } \\
88 \\
0\end{array}$ \\
\hline $\begin{array}{r}\text { Annual energy consumption } \\
\text { Atlanta (DB BIN/New WB BIN) } \\
\text { Houston } \\
\text { I.os Angeles } \\
\text { Minneapolis } \\
\text { New York } \\
\text { Orlando }\end{array}$ & $\begin{array}{l}\$ 3,366 / \$ 3,383 \\
\$ 2587 \\
\$ 1906 \\
\$ 1981 \\
\$ 3367 \\
\$ 2776\end{array}$ & $\begin{array}{c}\$ 10,098 / \$ 10,147 \\
\$ 7762 \\
\$ 5717 \\
\$ 5942 \\
\$ 10100 \\
\$ 8328\end{array}$ & $\begin{array}{c}\$ 26,928 / \$ 27,060 \\
\$ 20698 \\
\$ 15246 \\
\$ 15845 \\
\$ 26933 \\
\$ 22209\end{array}$ \\
\hline Dimensions & 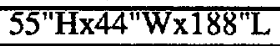 & $88^{\prime \prime} \times 74^{\prime \prime} \times 211^{\prime \prime}$ & $148^{\prime \prime} \times 120^{\prime \prime} \times 285^{\prime \prime}$ \\
\hline Approximate sales price to market & $\$ 11100$ & $\$ 24750$ & $\$ 53650$ \\
\hline
\end{tabular}

\section{Key Benefits and Weaknesses:}

Benefits include a very significant reduction in operating cost over options 1,2 and 3 , as well as the greatest reduction in refrigeration tons required. The sensible whecl provides the required reheat without allocating any energy source for this benefit since the heat comes from the space sensible load. This approach provides the most consistent outdoor air conditions to the cooling coil making it ideally suited for cost effective DX cooling. The energy recovery wheel also provides very significant wintertime energy savings as well as free humidification. It protects the coils during winter operation. Peak demand is cut significantly.

Weaknesses include slightly higher cost than options 1-3 for the system (although reduced cooling and heating plant often offset this difference) and a larger size since it incorporates two wheels. Biggest weakness is that it needs an exhaust air volume to operate.

* Design Based on outdoor air at $95 \mathrm{deg} / 115$ grains, supply outdoor air at 50 grains, $65-75$ degree dry bulb ** Energy consumption based on continuous operation and local 1994 utility costs for commercial facility and adjusts for cooling tower, pumps \& parasitic fan energy assuming $1.5^{\prime \prime}$ of external static pressure, and includes cost of heating and humidifying supply air to 65 degrees and 35 grains during the heating season 


\section{Summary Sheet for Preconditioning Approach 5: Dual-wheel Dessicant-based Cooling and Post Cooling}

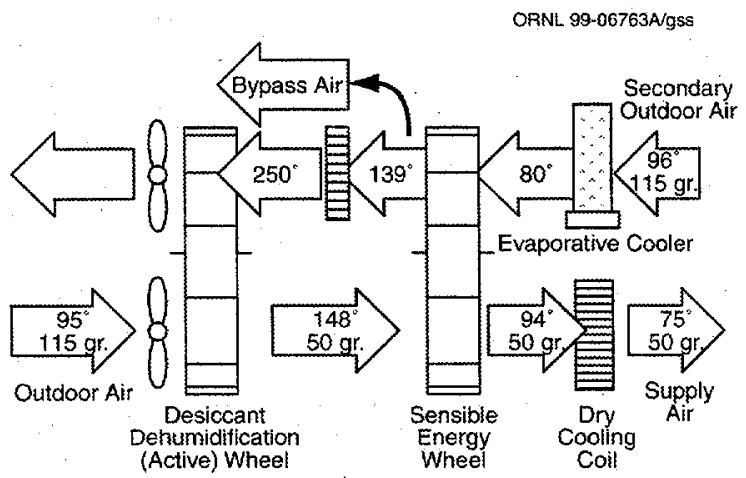

This approach uses two wheels, a dehumidification, and sensible recovery wheel to provide dry air at a moderate temperature. Heat is used to regenerate the dehumidification wheel once it has adsorbed moisture from the outdoor airstream. An evaporative cooler is usually required to enhance the cooling effect associated with the sensible wheel. Modest post cooling is often required during peak conditions.

Approach 5. Dual whecl desiccant-based cooling.

\begin{tabular}{|c|c|c|c|}
\hline \multirow{2}{*}{$\begin{array}{l}\text { Preconditioning Approach } \\
\text { Analysis Summary }\end{array}$} & \multicolumn{3}{|c|}{ System CFM (Nominal) } \\
\hline & 2500 & 7500 & 20000 \\
\hline $\begin{array}{l}\text { Conventional cooling tons at design* } \\
\text { Electrical demand at design* (KW) } \\
\text { Reheat energy at design* (BTU) }\end{array}$ & $\begin{array}{l}4 \text { tons } \\
7 \\
159875\end{array}$ & $\begin{array}{l}12 \text { tons } \\
21 \\
479625\end{array}$ & $\begin{array}{l}32 \text { tons } \\
57 \\
1279000\end{array}$ \\
\hline $\begin{array}{r}\text { Annual energy consumption } \\
\text { Atlanta (DB BIN/New WB BIN) } \\
\text { Houston } \\
\text { Los Angeles } \\
\text { Minneapolis } \\
\text { New York } \\
\text { Orlando } \\
\end{array}$ & $\begin{array}{l}\$ 4,433 / \$ 4072 \\
\$ 4718 \\
\$ 3925 \\
\$ 3542 \\
\$ 4948 \\
\$ 6308 \\
\end{array}$ & \begin{tabular}{|c|}
$\$ 13,298 / \$ 12,216$ \\
$\$ 14154$ \\
$\$ 11774$ \\
$\$ 10626$ \\
$\$ 14843$ \\
$\$ 18925$ \\
\end{tabular} & $\begin{array}{c}\$ 35,463 / \$ 32,573 \\
\$ 37744 \\
\$ 31397 \\
\$ 28336 \\
\$ 39582 \\
\$ 50466 \\
\end{array}$ \\
\hline Dimensions & $55^{\prime \prime} \mathrm{Hx} 44^{\prime \prime W x 188^{\prime \prime L}}$ & $88^{\prime \prime} \times 74^{\prime \prime} \times 211^{\prime \prime}$ & $148^{\prime \prime} \times 120^{\prime \prime} \times 285^{\prime \prime}$ \\
\hline Approximate sales price to market & $\$ 14700$ & $\$ 30215$ & $\$ 64838$ \\
\hline
\end{tabular}

\section{Key Benefits and Weaknesses:}

Benefits include the ability to shift the cooling load from high cost electricity to low cost gas. To provide air that is drier (in some cases) than obtainable with conventional cooling systems. Key advantage over desiccant based recovery wheels is that a return airstream is not necessary, although helpful. No wet cooling coils in this system.

Weaknesses include higher cost than previous options. The size of the system is quite large due to the two wheel arrangement operating at moderate face velocities. Often requires the evaporative cooler for economics, yet it can be a high maintenance item and is avoided in some applications.

* Design Based on outdoor air at $95 \mathrm{deg} / 115$ grains, supply outdoor air at 50 grains, $65-75$ degree dry bulb ** Energy consumption based on continuous operation and local 1994 utility costs for commercial facility and adjusts for cooling tower, pumps \& parasitic fan energy assuming 1.5 " of external static pressure, and includes cost of heating and humidifying supply air to 65 degrees and 35 grains during the heating season 


\section{Summary Sheet for Preconditioning Approach 6: Dessicant Dehumidification-Total Recovery Hybrid}

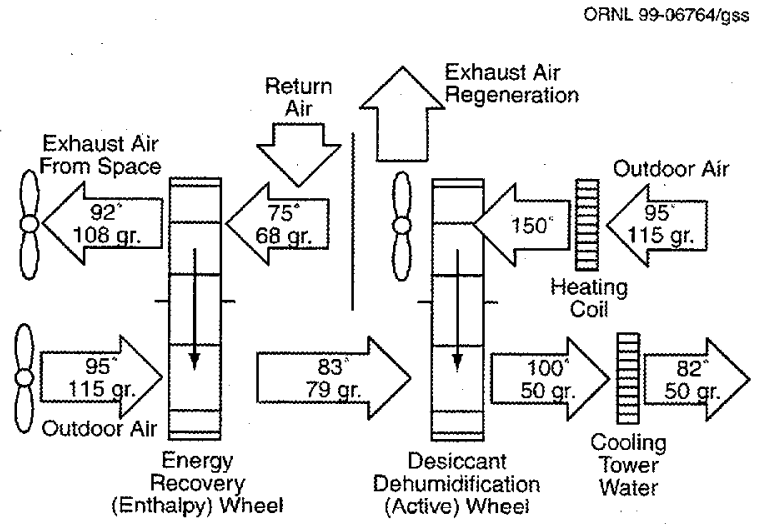

This approach combines the best of total recovery with the best of dehumidification wheel performance. The total energy wheel removes much of the moisture and precools the outdoor air, which is then introduced to a dehumidification wheel to remove only the remaining moisture desired.

Approach 6. Desiccant delumidilication - total recovery bybrid.

\begin{tabular}{|c|c|c|c|}
\hline \multirow{2}{*}{$\begin{array}{l}\text { Preconditioning Approach } \\
\text { Analysis Summary }\end{array}$} & \multicolumn{3}{|c|}{ System CFM (Nominal) } \\
\hline & 2500 & 7500 & 20000 \\
\hline Conventional cooling tons at design* & 6 tons & 17 tons & 45 tons \\
\hline Electrical demand at design* $(\mathrm{KW})$ & 9 & 28 & 73 \\
\hline Reheat energy at design* (BTU) & 78125 & 234375 & 625000 \\
\hline Annual energy consumption ${ }^{* *}$ & & & \\
\hline Atlanta & $\$ 4264$ & $\$ 12792$ & $\$ 34113$ \\
\hline Houston & $\$ 3455$ & $\$ 10365$ & $\$ 27640$ \\
\hline Los Angeles & $\$ 2857$ & $\$ 8571$ & $\$ 22856$ \\
\hline Minneapolis & $\$ 2661$ & $\$ 7983$ & $\$ 21288$ \\
\hline New York & $\$ 4442$ & $\$ 13327$ & $\$ 35538$ \\
\hline Orlando & $\$ 4592$ & $\$ 13777$ & $\$ 36738$ \\
\hline Dimensions & $55^{\prime \prime} \mathrm{Hx} 44^{\prime \prime} \mathrm{W} 203^{\prime \prime} \mathrm{L}$ & $88^{11} \times 74^{\prime \prime} \times 226^{\prime \prime}$ & $148^{\prime \prime} \times 120^{11} \times 300^{\prime \prime}$ \\
\hline Approximate sales price to market & $\$ 15750$ & $\$ 31350$ & $\$ 67850$ \\
\hline
\end{tabular}

\section{Key Benefits and Weaknesses:}

Benefits include the ability to shift the cooling load from high cost electricity to low cost gas. To provide air that is much drier than obtainable with conventional cooling systems. No wet cooling coils in this system. Since the DH wheel does less work than in option 5, the temperature leaving the desiccant is far more moderate, allowing the sensible recovery wheel to be replaced with a tower or conventional cooling coil. The energy efficiency (COP) when compared to option 5 is much improved if free post cooling is available or not required. Air much drier than possible with option 5 is produced using this approach. This approach also provides for latent recovery in the winter as well as summer.

Weaknesses include those listed for option 5 plus the fact that a return air stream is required for the total energy recovery wheel portion of the design.

* Design Based on outdoor air at 95 deg/115 grains, supply outdoor air at 50 grains, $65-75$ degree dry bulb

** Energy consumption based on continuous operation and local 1994 utility costs for commercial facility and adjusts for cooling tower, pumps \& parasitic fan energy assuming 1.5" of external static pressure, and includes cost of heating and humidifying supply air to 65 degrees and 35 grains during the heating season 


\section{Summary Sheet for Preconditioning Approach 7: Dual-wheel Dessicant- based Cooling-Total Recovery Hybrid}

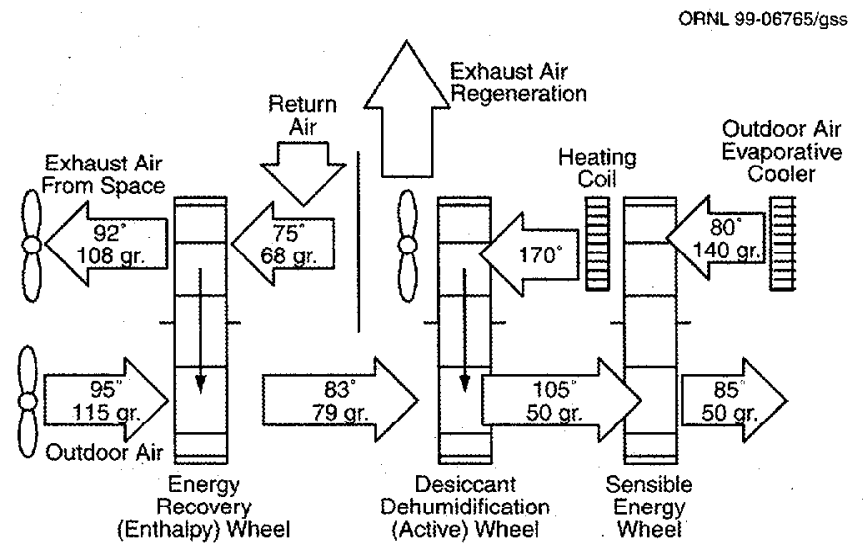

This approach combines the best of total recovery with the best of dessicant-based cooling performance. The total energy wheel removes much of the moisture and precools the outdoor air, which is then introduced to a dehumidification wheel to remove only the remaining moisture desired. The added sensible wheel eliminates the need for post cooling at most conditions while reducing the regeneration energy consumption.

Approach 7. Dual wheel desiccant-based cooling-total recovery hybrid.

\begin{tabular}{|c|c|c|c|}
\hline \multirow{2}{*}{$\begin{array}{c}\text { Preconditioning Approach } \\
\text { Analysis Summary }\end{array}$} & \multicolumn{3}{|c|}{ System CFM (Nominal) } \\
\hline & 2500 & 7500 & 20000 \\
\hline $\begin{array}{l}\text { Conventional cooling tons at design* } \\
\text { Electrical demand at design* (KW) } \\
\text { Reheat energy at design* (BTU) }\end{array}$ & $\begin{array}{l}2 \text { tons } \\
6 \\
70000\end{array}$ & $\begin{array}{l}6.5 \text { tons } \\
17 \\
210000\end{array}$ & $\begin{array}{l}17 \text { tons } \\
45 \\
560000\end{array}$ \\
\hline $\begin{array}{r}\text { Annual encrgy consumption }{ }^{* *} \\
\text { Atlanta } \\
\text { Houston } \\
\text { Los Angeles } \\
\text { Minneapolis } \\
\text { New York } \\
\text { Orlando }\end{array}$ & $\begin{array}{l}\$ 3158 \\
\$ 3030 \\
\$ 2506 \\
\$ 2334 \\
\$ 3573 \\
\$ 3924\end{array}$ & $\begin{array}{l}\$ 9474 \\
\$ 9091 \\
\$ 7517 \\
\$ 7001 \\
\$ 10719 \\
\$ 11772 \\
\end{array}$ & $\begin{array}{l}\$ 25264 \\
\$ 24242 \\
\$ 20045 \\
\$ 18669 \\
\$ 28584 \\
\$ 31392\end{array}$ \\
\hline Dimensions & $55^{\prime \prime} \mathrm{Hx} 44^{\prime \prime} \mathrm{W} \times 235^{\prime \prime} \mathrm{L}$ & $88^{11} \times 74^{11} \times 258^{\prime \prime}$ & $148^{\prime \prime} \times 120^{\prime \prime} \times 332^{\prime}$ \\
\hline Approximate sales price to market & $\$ 20500$ & $\$ 39300$ & $\$ 84200$ \\
\hline
\end{tabular}

\section{Key Benefits and Weaknesses:}

Benefits include the ability to shift the cooling load from high cost electricity to low cost gas. To provide air that is much drier than obtainable with conventional cooling systems. No wet cooling coils in this system. Since the DH wheel does less work than in option 5, the temperature leaving the desiccant is far more moderate, allowing the sensible recovery wheel to replace the tower water or conventional cooling coil. The energy cfficiency (COP) when compared to option $5 \& 6$ is much improved.

Weaknesses include those listed for option 5 plus the fact that a return air stream is required for the total energy recovery wheel portion of the design. Due to the three wheels involved, space is very often a problem and the cost is at a premium of over other approaches.

* Design Based on outdoor air at $95 \mathrm{deg} / 115$ grains, supply outdoor air at 50 grains, 65-75 degree dry bulb ** Energy consumption based on continuous operation and local 1994 utility costs for commercial facility and adjusts for cooling tower, pumps \& parasitic fan energy assuming 1.5" of external static pressure, and includes cost of heating and humidifying supply air to 65 degrees and 35 grains during the heating season 



\section{APPENDIX B}

DETAILED SPECIALIZED OUTDOOR AIR HANDLING UNIT (SOAHU) MODELING INPUTS AND RESULTS FOR ATLANTA and DESSICANT-BASED COOLING MODELING DATA FOR HOUSTON, MINNEAPOLIS, NEW YORK, AND ORLANDO 


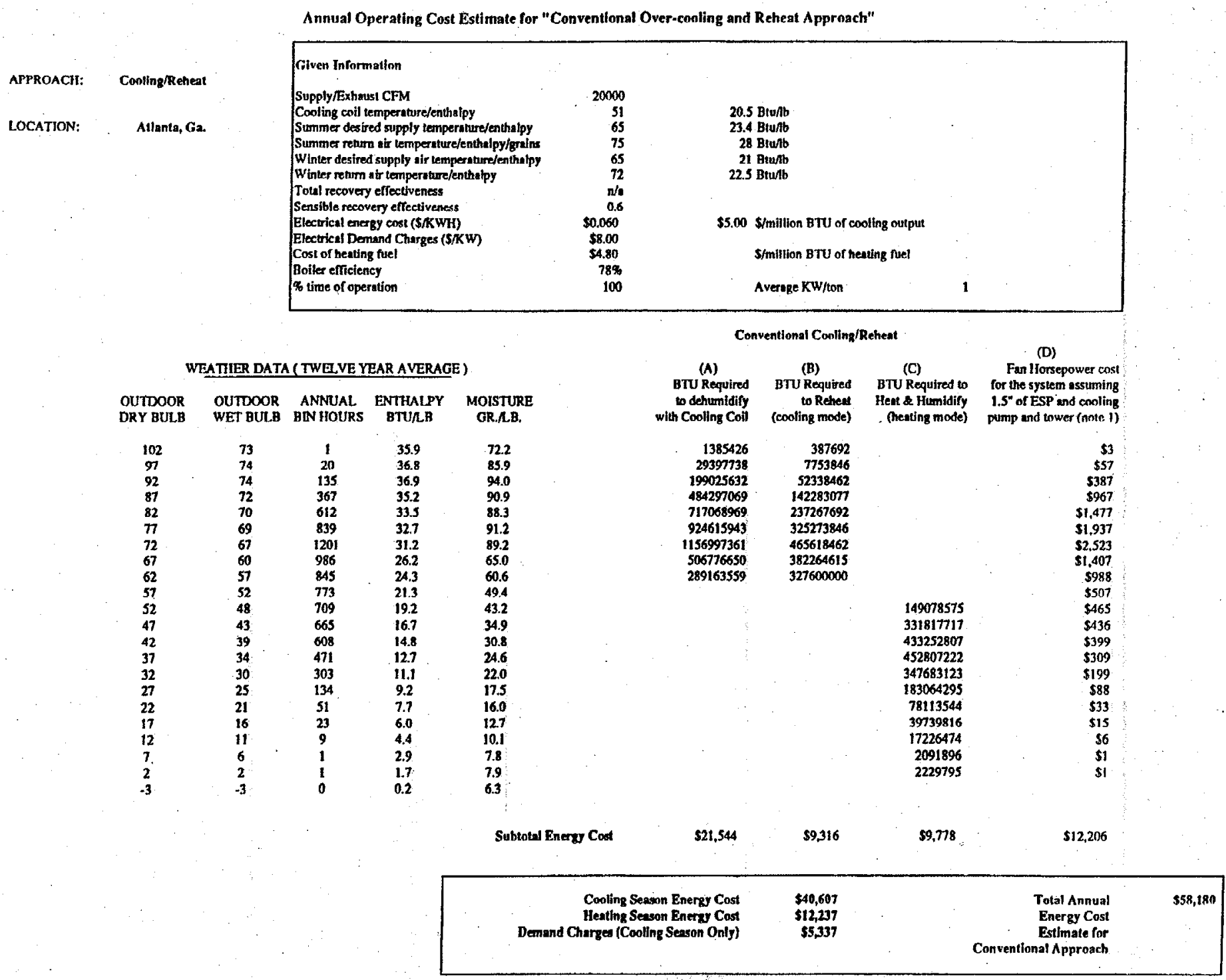




\begin{tabular}{|c|c|c|c|c|c|c|c|c|c|c|}
\hline \multirow[t]{5}{*}{$\begin{array}{l}\text { APRROACH: } \\
\text { LOCATON: }\end{array}$} & \multirow{2}{*}{\multicolumn{2}{|c|}{ 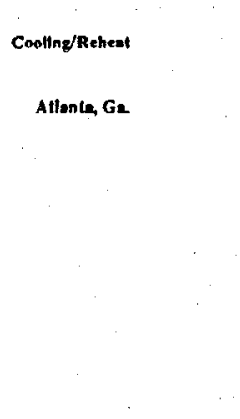 }} & \multicolumn{3}{|c|}{ 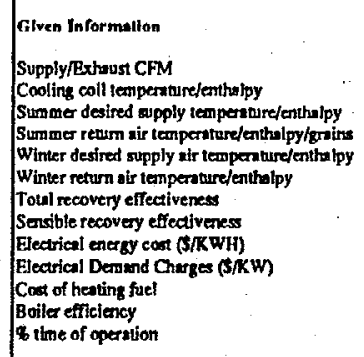 } & 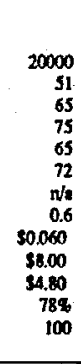 & \multicolumn{3}{|c|}{ 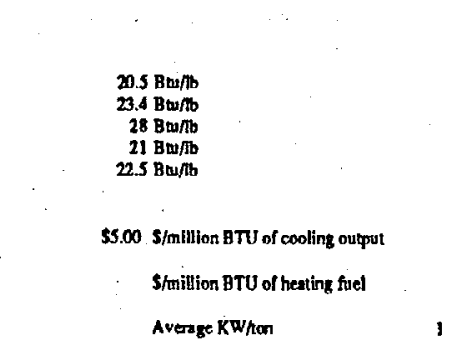 } & \\
\hline & & & & & & & \multicolumn{3}{|c|}{ Conventlonal Coolling/Reheat } & \\
\hline & \multicolumn{5}{|c|}{ WEATHER DATA (TWELLE YEAR AVERAGE) } & & \multirow{2}{*}{ 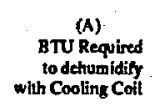 } & \multirow{2}{*}{ 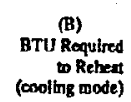 } & \multirow{2}{*}{ 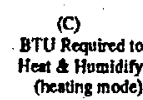 } & \multirow{2}{*}{ 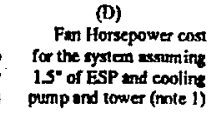 } \\
\hline & $\begin{array}{l}\text { OUTDOOR } \\
\text { DRY BUILB }\end{array}$ & $\begin{array}{l}\text { OUTDOORR } \\
\text { WET BULLR }\end{array}$ & $\begin{array}{l}\text { ANAUAL } \\
\text { BNA HOURS }\end{array}$ & $\begin{array}{l}\text { ENTHALPY } \\
\text { TTURB }\end{array}$ & $\begin{array}{l}\text { MoIsture } \\
\text { GR } \Omega \text { B. }\end{array}$ & & & & & \\
\hline & $\begin{array}{l}87 \\
86 \\
83 \\
78 \\
73 \\
74 \\
72 \\
69 \\
67 \\
66 \\
64 \\
62 \\
61 \\
69 \\
99 \\
57 \\
35 \\
52 \\
50 \\
48 \\
45 \\
43 \\
42 \\
37 \\
32 \\
27 \\
27 \\
17 \\
12\end{array}$ & $\begin{array}{l}78.5 \\
76.5 \\
74.5 \\
72.5 \\
70.5 \\
60.5 \\
66.5 \\
64.5 \\
64.5 \\
62.5 \\
60.5 \\
58.5 \\
56.5 \\
54.5 \\
52.5 \\
50.5 \\
48.5 \\
46.5 \\
44.5 \\
42.5 \\
40.5 \\
39.5 \\
3.65 \\
32.5 \\
29 \\
24 \\
20 \\
15 \\
12\end{array}$ & 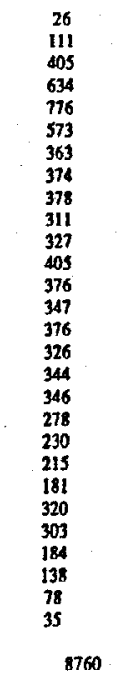 & 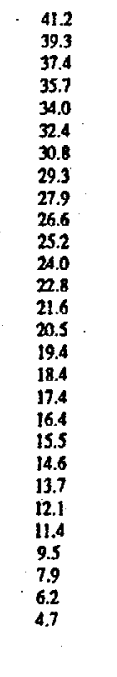 & 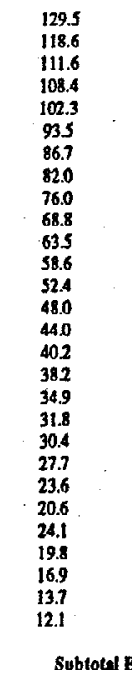 & $\operatorname{cost}$ & 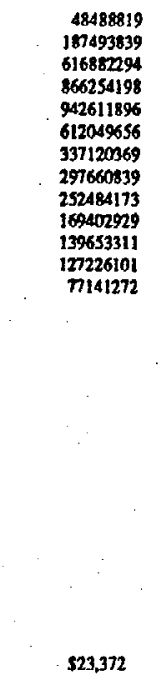 & 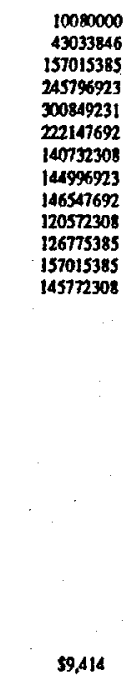 & 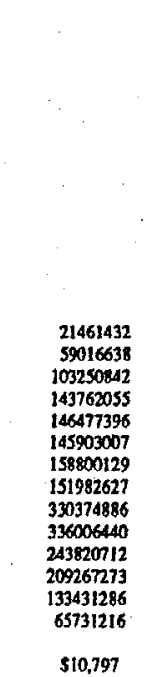 & 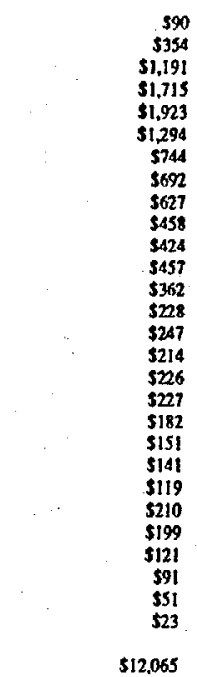 \\
\hline & & & & & & & 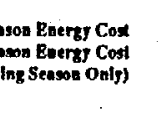 & 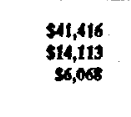 & & 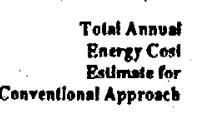 \\
\hline
\end{tabular}


Annual Opcrating Cost Estimate for "Conventional Over-cooling, Run-Around Recovery, Reheat Appraach"

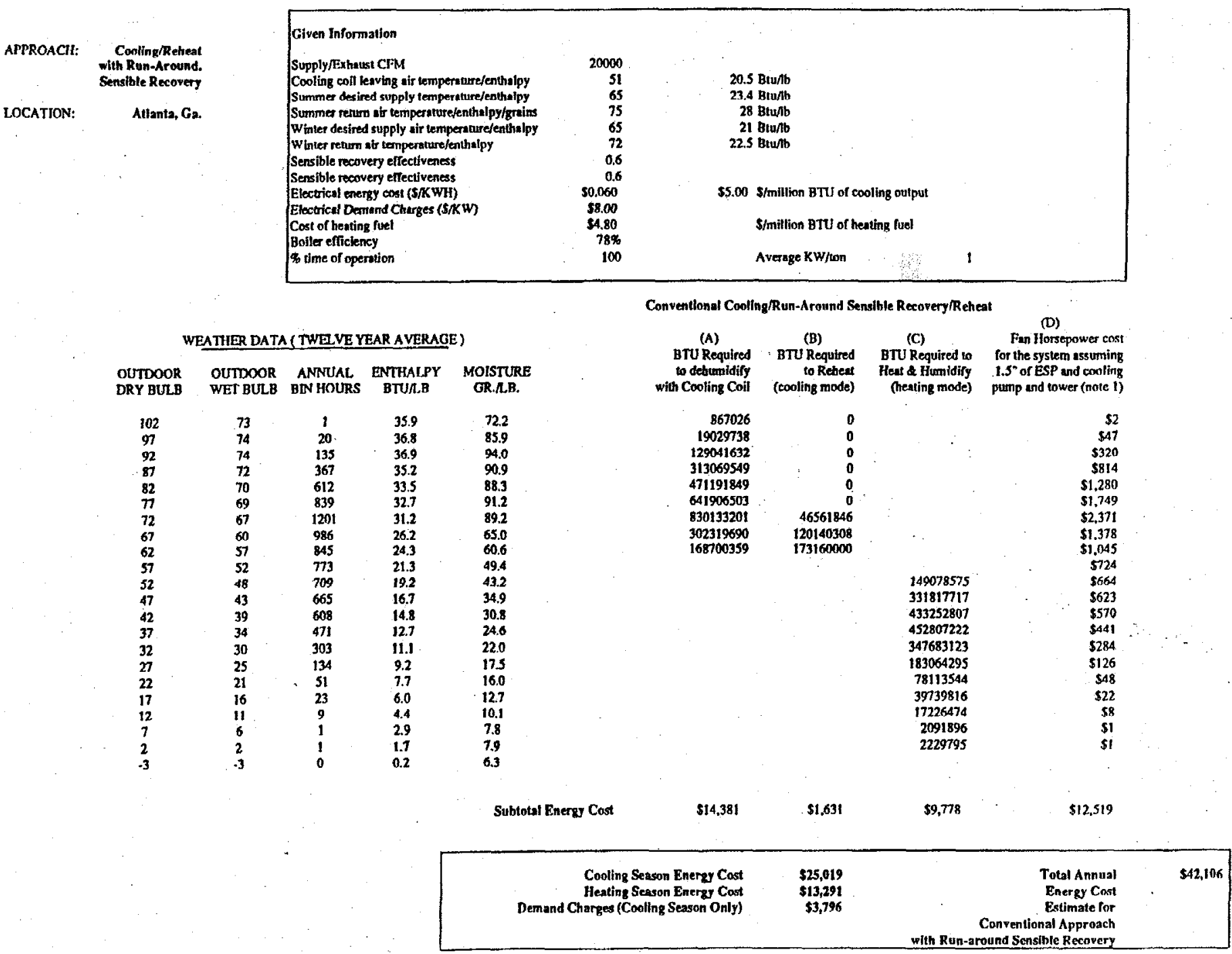


(E)

Supply Air Temp

Entering Reheal
Coil

(F)

Outdoor A

Cooling Coil

$\begin{array}{rr}75 & 30.13 \\ 75 & 31.07 \\ 75 & 31.12 \\ 72.6 & 29.98 \\ 69.6 & 29.05 \\ 66.6 & 29.00 \\ 63.6 & 28.18 \\ 60.6 & 23.91 \\ 57.6 & 22.72\end{array}$

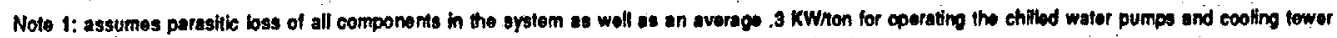

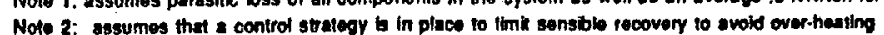


Annual Operating Cost Estimate for "Total Recovery with Conventional Cooling and Reheat"

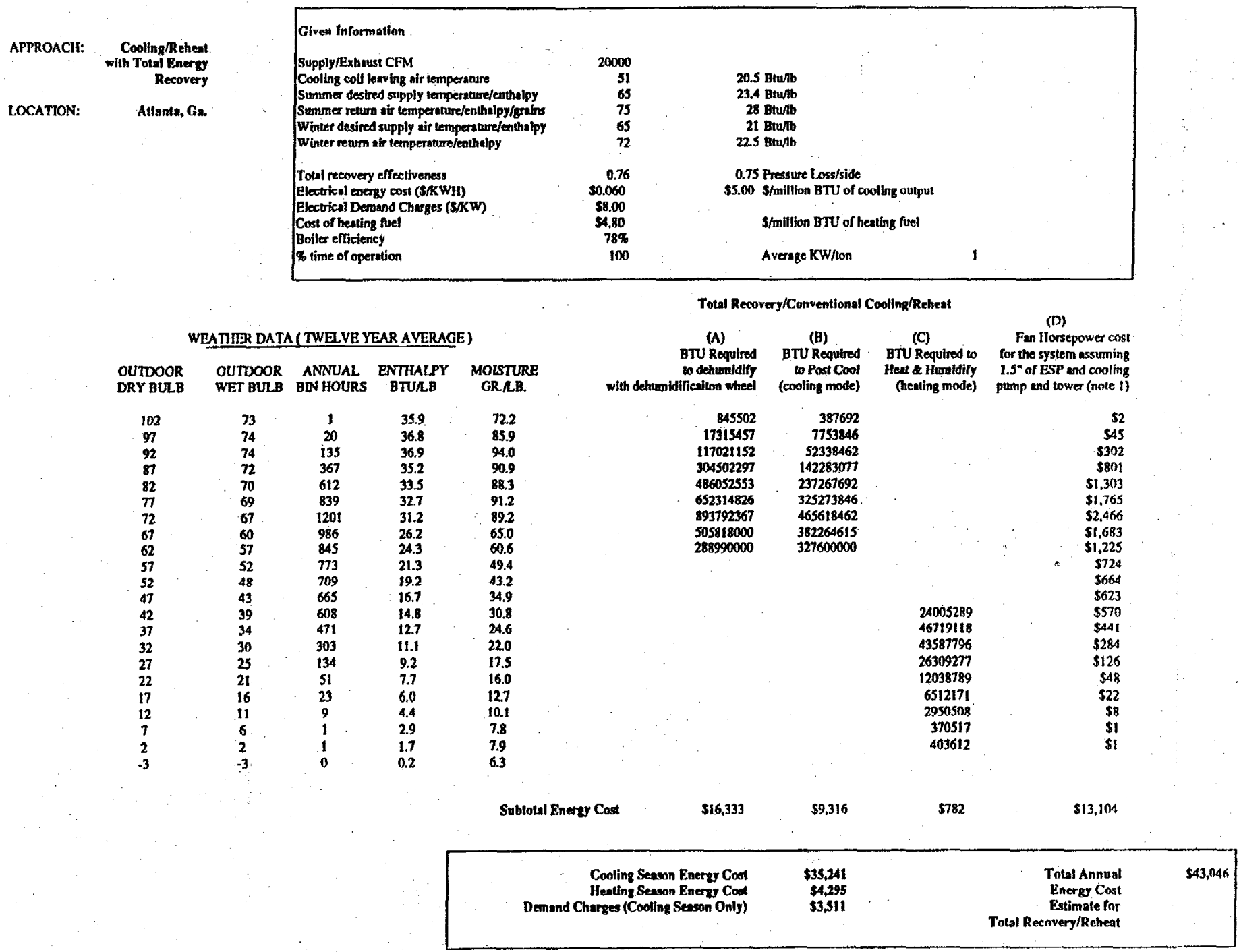




$$
\pi
$$


Annual Operaling Cost Estimate for "Dual wheel Total Recovery/Conventional Cooling/Sensihle Recovery Reheat Approach"

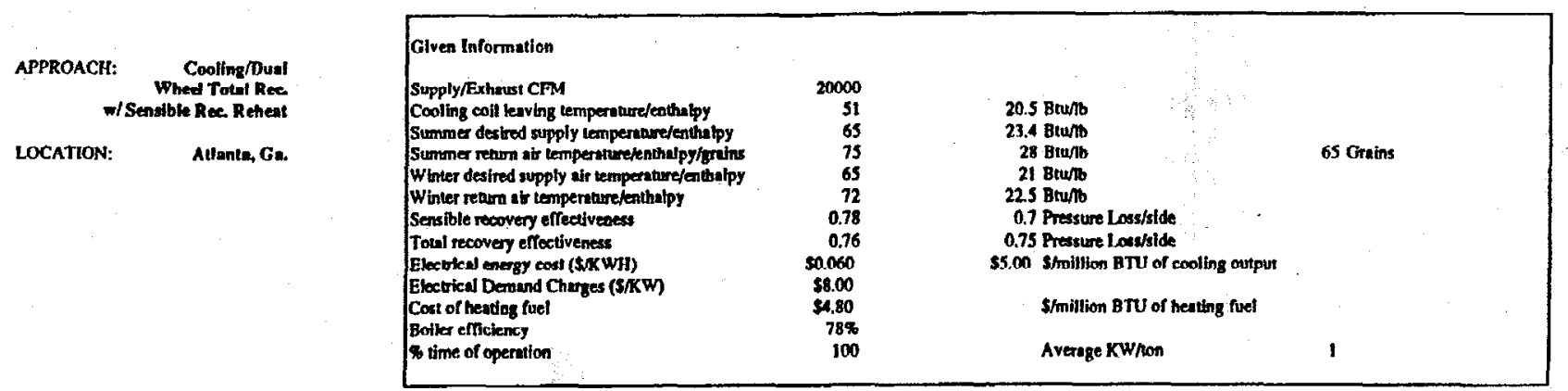

Dual Whed Tolal Recovery/Conventlonal Conling/Sensible Recovery Rehest

WBATHER DATA (TWE VE YEAR AVERAGE)

\begin{tabular}{|c|c|c|c|}
\hline $\begin{array}{l}\text { OUTDOOR } \\
\text { DRY BUIB B }\end{array}$ & $\begin{array}{l}\text { OUTPOOR } \\
\text { WET BULBB }\end{array}$ & $\begin{array}{l}\text { ANNUAL } \\
\text { BNN HOURS }\end{array}$ & $\begin{array}{l}\text { ENTHALY } \\
\text { BTURB }\end{array}$ \\
\hline 102 & 73 & l & 35.9 \\
\hline 97 & 74 & 20 & 36.8 \\
\hline 92 & 74 & 135 & 36.9 \\
\hline 87 & 12 & 367 & 35.2 \\
\hline 82 & 70 & 612 & 33.5 \\
\hline$\pi$ & 69 & 839 & 32.7 \\
\hline 72 & 67 & $\begin{array}{l}1201 \\
1201\end{array}$ & 31.2 \\
\hline $\begin{array}{l}62 \\
67\end{array}$ & 60 & 986 & 26.2 \\
\hline $\begin{array}{l}87 \\
62\end{array}$ & 57 & 845 & 24.3 \\
\hline $\begin{array}{l}82 \\
37\end{array}$ & 52 & 773 & 21.3 \\
\hline$\$ 2$ & 48 & 709 & $\begin{array}{l}19.2 \\
\text { S }\end{array}$ \\
\hline 47 & $\begin{array}{l}88 \\
43\end{array}$ & 665 & 16.7 \\
\hline 42 & $\begin{array}{l}43 \\
39\end{array}$ & 608 & 14.8 \\
\hline 37 & $\begin{array}{l}39 \\
34\end{array}$ & 471 & 12.7 \\
\hline 32 & 30 & 301 & 11.1 \\
\hline & 25 & 134 & 9.2 \\
\hline $\begin{array}{l}21 \\
22\end{array}$ & 21 & 51 & 7.7 \\
\hline 17 & 16 & 23 & 6.0 \\
\hline 12 & 11 & 9 & 4.4 \\
\hline 7 & 6 & 1 & 2.9 \\
\hline 2 & 2 & 1 & 1.7 \\
\hline-3 & -3 & 0 & 0.2 \\
\hline
\end{tabular}

GOISTURE

(A)
BTU Required BTU Required

(C)
BTU Required to
Heat \& Humtdify
(menting made)

Fan (D) to Reheal
with Conting Coll
(cooling mode)

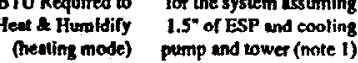

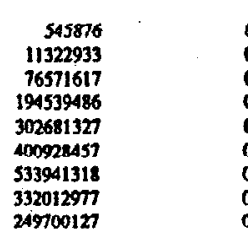

0
0
0
0
0
0
0
0
0

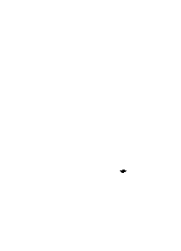

$\$ 2$
$\$ 39$
$\$ 267$
505
$\$ 1,142$
$\$ 1,545$
$\$ 2,152$
$\$ 1,607$
51,325
$\$ 569$
$\$ 797$
548
$\$ 584$
$\$ 530$
$\$ 341$
$\$ 151$
$\$ 57$
$\$ 26$
$\$ 10$
$\$ \$ 1$
$\$ 1$

Subtotsl Energy Cost

\$10,511

so

\section{9}

46719118

263899277

12038789

6512171

2950508
370517

370517
403612

(note 1)
coming

5782

$\$ 12,998$

\begin{tabular}{|c|c|c|c|}
\hline $\begin{array}{l}\text { Cooling Season Enery Cost } \\
\text { Hexilug Seavón Enery Cost } \\
\text { Demand Charges (Coolling Season Only) }\end{array}$ & $\begin{array}{r}\$ 19,294 \\
\$ 4,997 \\
\$ 2,637\end{array}$ & $\begin{array}{r}\text { Total Annual } \\
\text { Energy Cost } \\
\text { Estimate for Dust Wheet } \\
\text { Total Recovery/Sensible Rec, Reheat }\end{array}$ & $\$ 26,928$ \\
\hline
\end{tabular}




\begin{tabular}{|c|c|c|c|}
\hline $\begin{array}{r}\text { (E) } \\
\text { Supply Atr Temp } \\
\text { Entering Reheat } \\
\text { Coll }\end{array}$ & $\begin{array}{c}\text { (F) } \\
\text { Outdoor Air } \\
\text { Enthalpy Entering } \\
\text { Cooling Coil }\end{array}$ & $\begin{array}{c}\text { (G) } \\
\text { Exhaust Air Temp } \\
\text { Entering Total } \\
\text { Energy Wheel }\end{array}$ & $\begin{array}{c}\text { (H) } \\
\text { Exhaust Afr Enthalpy } \\
\text { Entering Total } \\
\text { Energy Wheel }\end{array}$ \\
\hline 69.6 & 26.57 & 56.4 & 23.6 \\
\hline 69.6 & 26.79 & 56.4 & 23.6 \\
\hline 69.6 & 26.80 & $56: 4$ & 23.6 \\
\hline 69.6 & 26.39 & 56.4 & 23.6 \\
\hline 69.6 & 26.00 & 56.4 & 23.6 \\
\hline 69.6 & 25.81 & 56.4 & 23.6 \\
\hline 69.6 & 25.44 & 56.4 & 23.6 \\
\hline 69.6 & 24.24 & 56.4 & 23.6 \\
\hline 69.6 & 23.78 & 56.4 & 23.6 \\
\hline
\end{tabular}

20.66

20.14

19.75

19.30

18.95

18.55

18.16

17.79

17.50

Note 1: assumes parasitic loss of all components in the system es woll as an average .3 KWhon for operating the chilled water pumps and cooling tower 
Annual Operating Cost Estimate for "Traditional Desiceant Based Conling Approach"

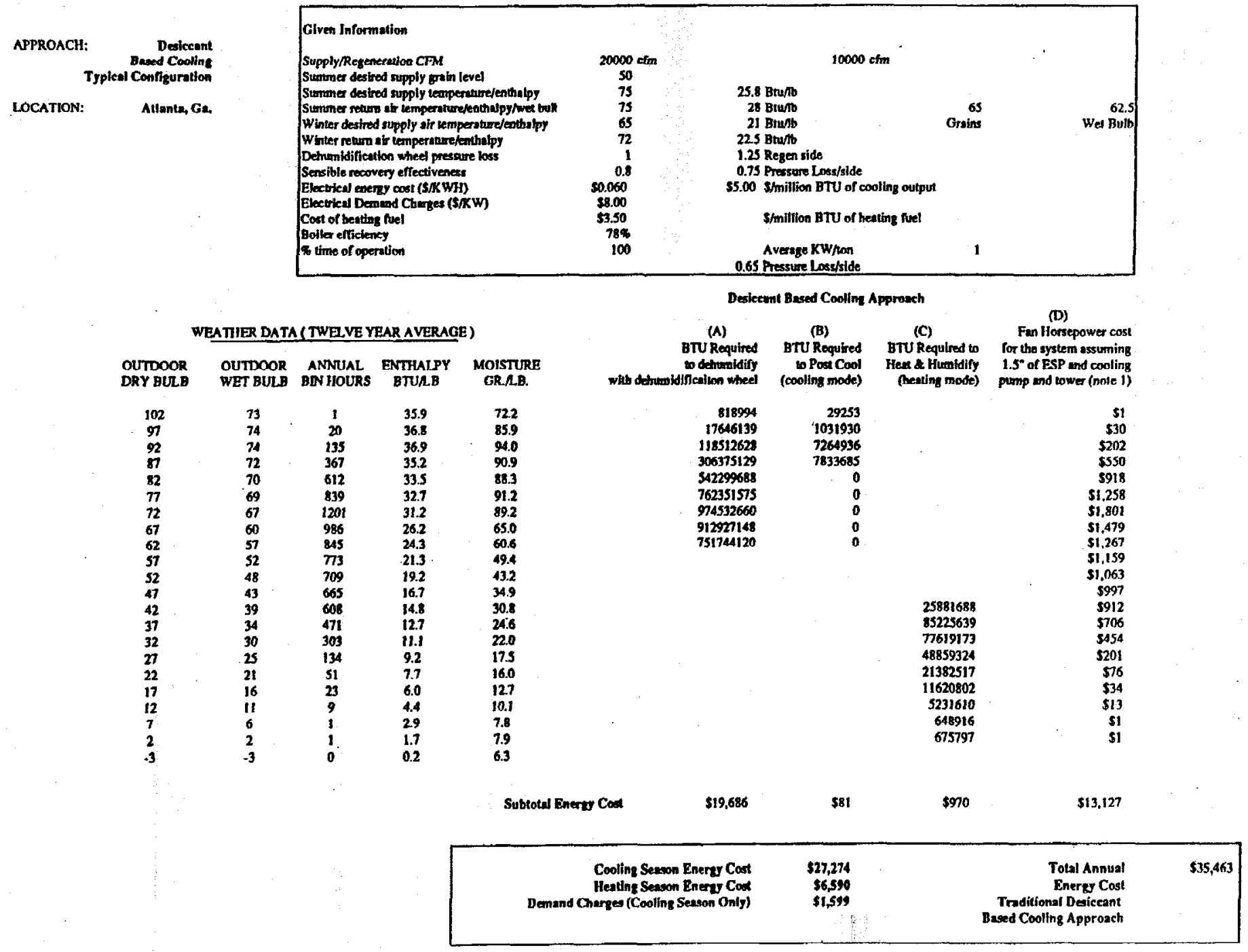




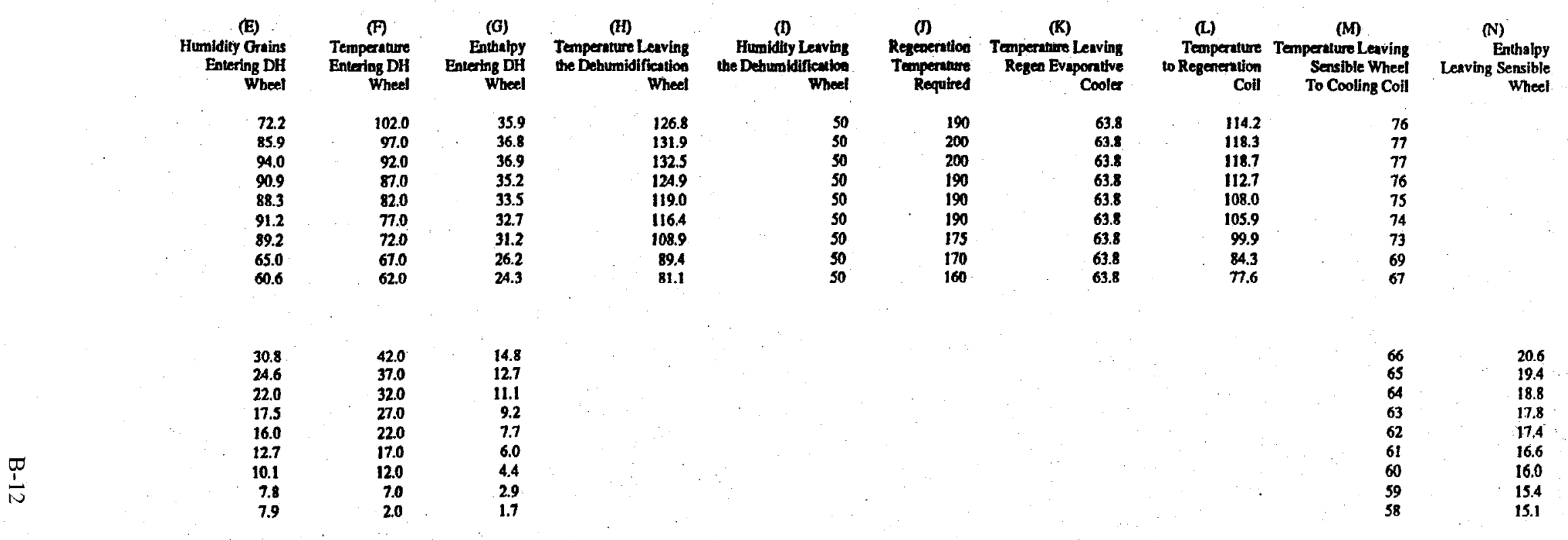


Annual Operating Cost Estimate for "Dehumldificaltiow/Total Recovery Hybrid Approach"

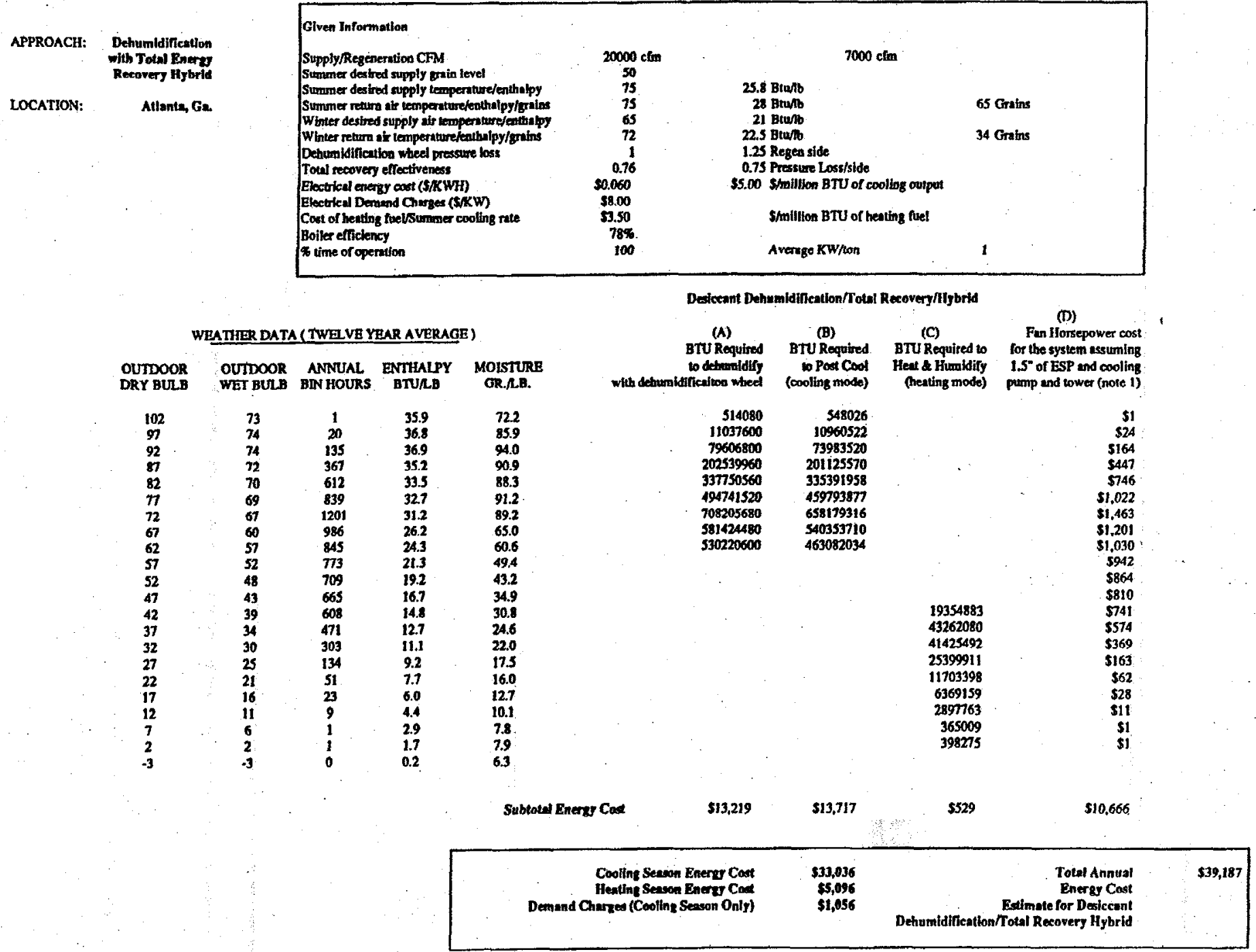


(E)

Hunidity Grains Entering DH

Whed

66.7

70.0

72.0

71.2

70.6

71.3

70.8

65.0

63.9

33,2

31.7

31.1

30.0

29.7

28.9

28.3

27.7

27.7.
(F)

Temperenure

Entering DH

Wheel

81.5

80.3

79.1

77.9

76.7

75.5

74.3

73.1

71.9

64.8

63.6

62.4

61.2

60.0
58.8

57.6

56.4

55.2
(I)

(G)

Enthalpy Temperature Leaving

Entaing DH

Wheel

30.0

30.2

30.2

29.8

29.4

29.3

28.9

27.7

27.2

ha Dehumidifintion

Wheel

100.4

101.3

101.4

98.8

96.9

96.2

94.3

89.3

87.6
(D)

Humidity Levving

the Detemitiventos

Hocel

50

50

50

50

50

50 .
(D)

Regeneration

Teonperaners

Requined

170

170

170

160

155

155

150

145

Note1: essumes parasitic lose for all components in the system as well as an avorage.3KWhon for operating the chilibd wator pumps and aperating the cooling tower 
Annual Operating Cost Estimale for "Total Recovery with Traditional DBC Approscb"

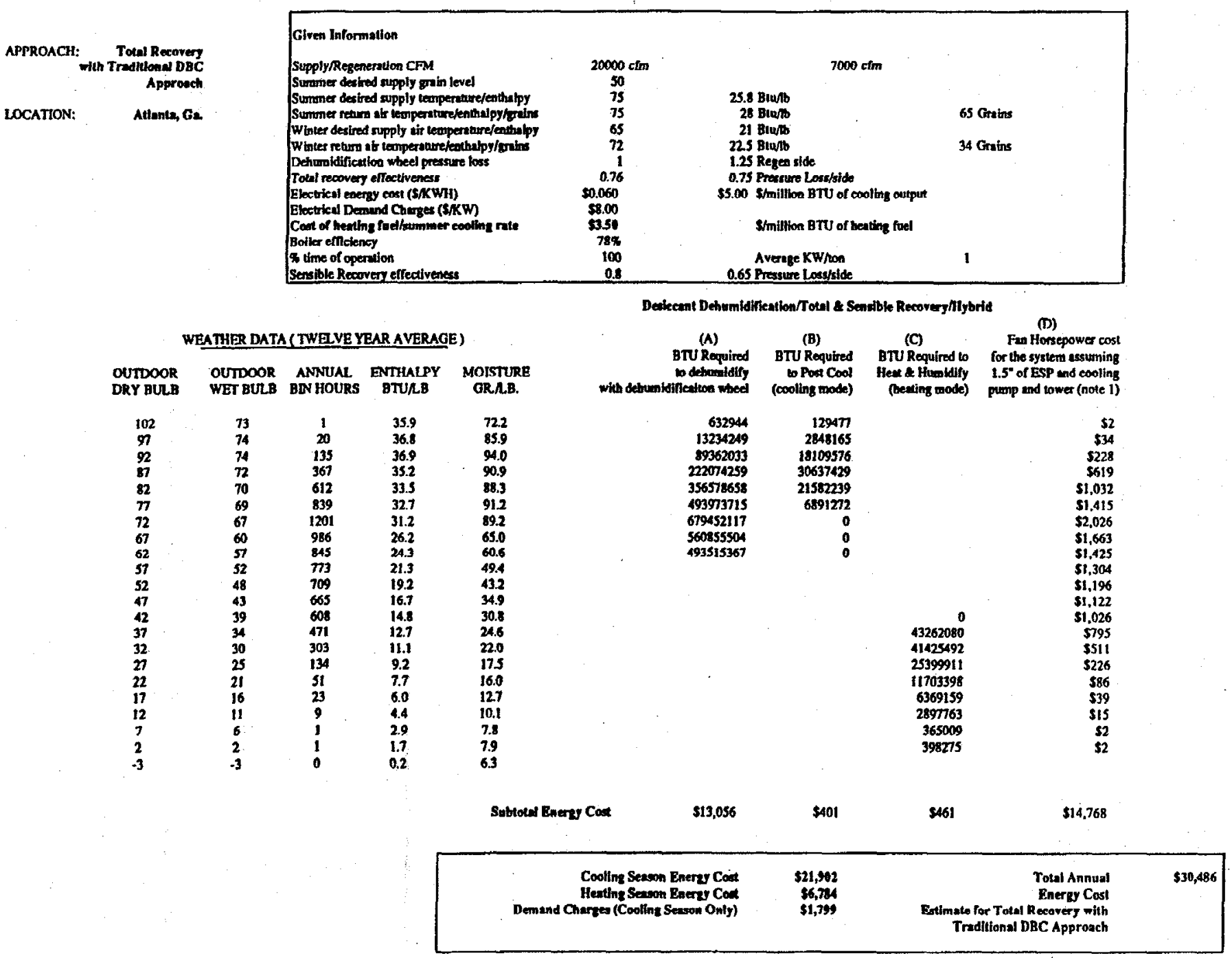


(E)

Ilumidity Grains

Entering DH

Whed

66.7

70.0

72.0

71.2

70.6

71.3

70.8

65.0

63.9

33.2

31.7

31.1

30.0

29.7

28.9

28.3

27.7

277
(F)

Temperiture

Entering DH

Wheel

81.5

80.3

79.1

77.9

76.7

75.5

743

73.1

71.9

64.8

63.6

624

61.2

60.0

58.8

57.6

55.2
(H)

Enthalpy

Wheel
Whing DH

Tempenture Leaving

the Debunidification

Wheel

100.4

101.3

101.4

98.8

96.9

96.2

94.3

89.3

87.6
(I)

Humidity Leaving

the Deburidification
Wheel

50

so

so

so

50

50
50

50
50
(J)

Regenerntion

Tenperearro
Required

170

170
160

155

155

150

145

Note1: essumes parasitic loss for all components in the system as well as an awerage, 3KWhon for cperating thi chilind water pumps and operting the cooling tower 


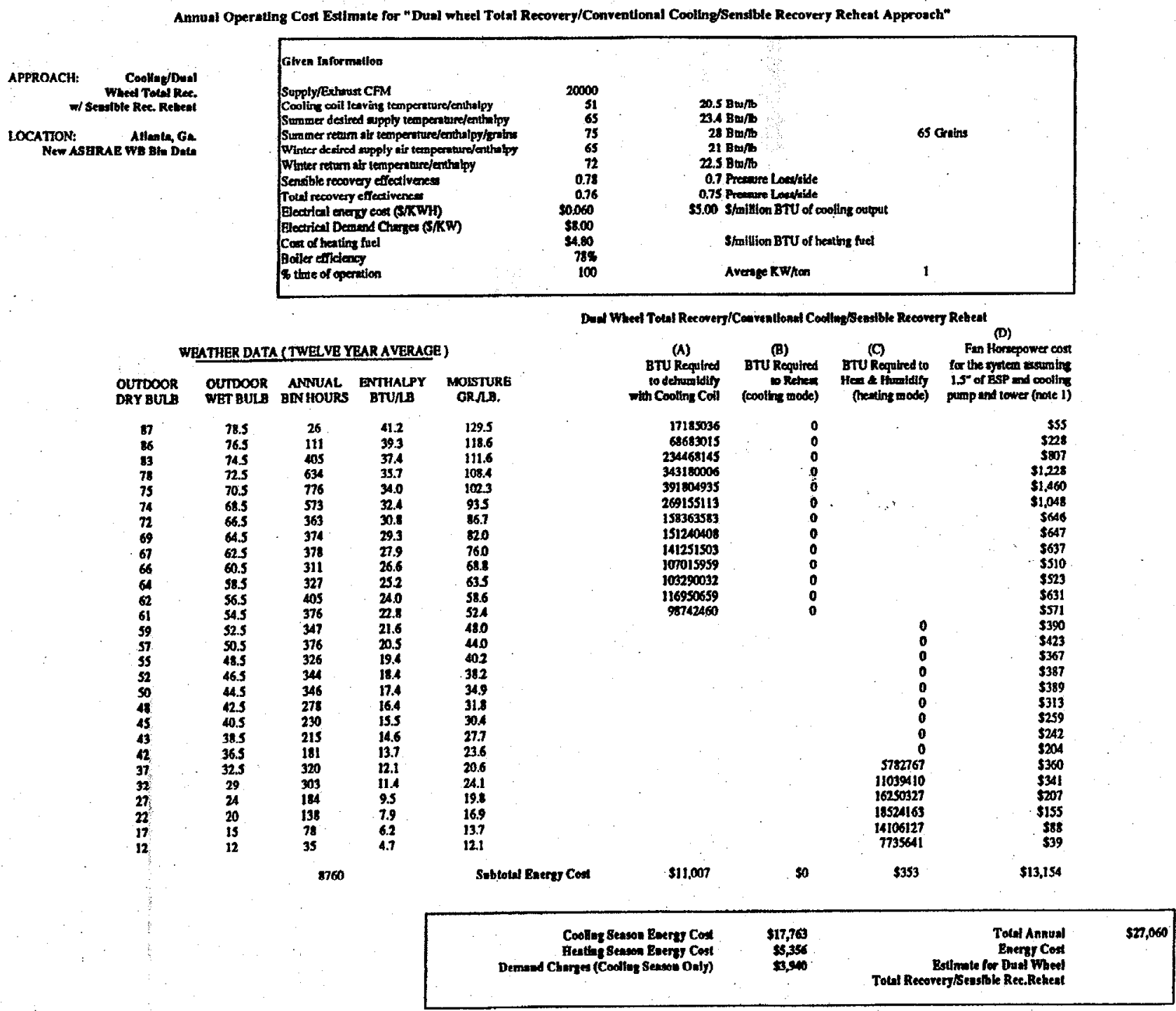


(E)

Supply Air Temp

Evering Retient

Enthalp Entering

Ovidoor Ai

Cooling Coil

$\begin{array}{ll}69.6 & 27.84 \\ 69.6 & 27.38\end{array}$

69.626 .93

$69.6 \quad 26.51$

$69.6 \quad 26.11$

$69.6 \quad 25.72$

$69.6 \quad 25.35$

$69.6 \quad 24.99$

$69.6 \quad 24.65$

69.6224 .01

$69.6 \quad 23.71$

$69.6 \quad 23.42$

23.14

22.87

22.61

22.37

22.13

21.89

21.67

21.45

21.24

20.84

20.68

20.23

19.84

19.43

19.08
$69.6 \quad 24.32$

(H)

Brhaunt Ait Enthalpy

Enceris Toul Enering Toul
Fnersy Whed

$56,4 \quad 23.6$

$\begin{array}{ll}56.4 & 23.6 \\ 56.4 & 23.6\end{array}$

$56.4: \quad 23.6$

$56.4 \quad 23.6$.

56.4

$56.4 \quad 23.6$

$56.4 \quad 23.6$

$56.4 \quad 23.6$

$56.4 \quad 23.6$

$56.4 \quad 23.6$

$\begin{array}{ll}56.4 & 23.6\end{array}$

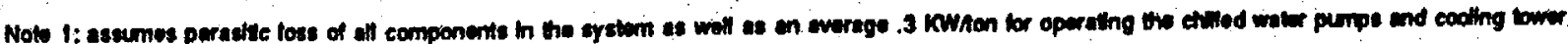




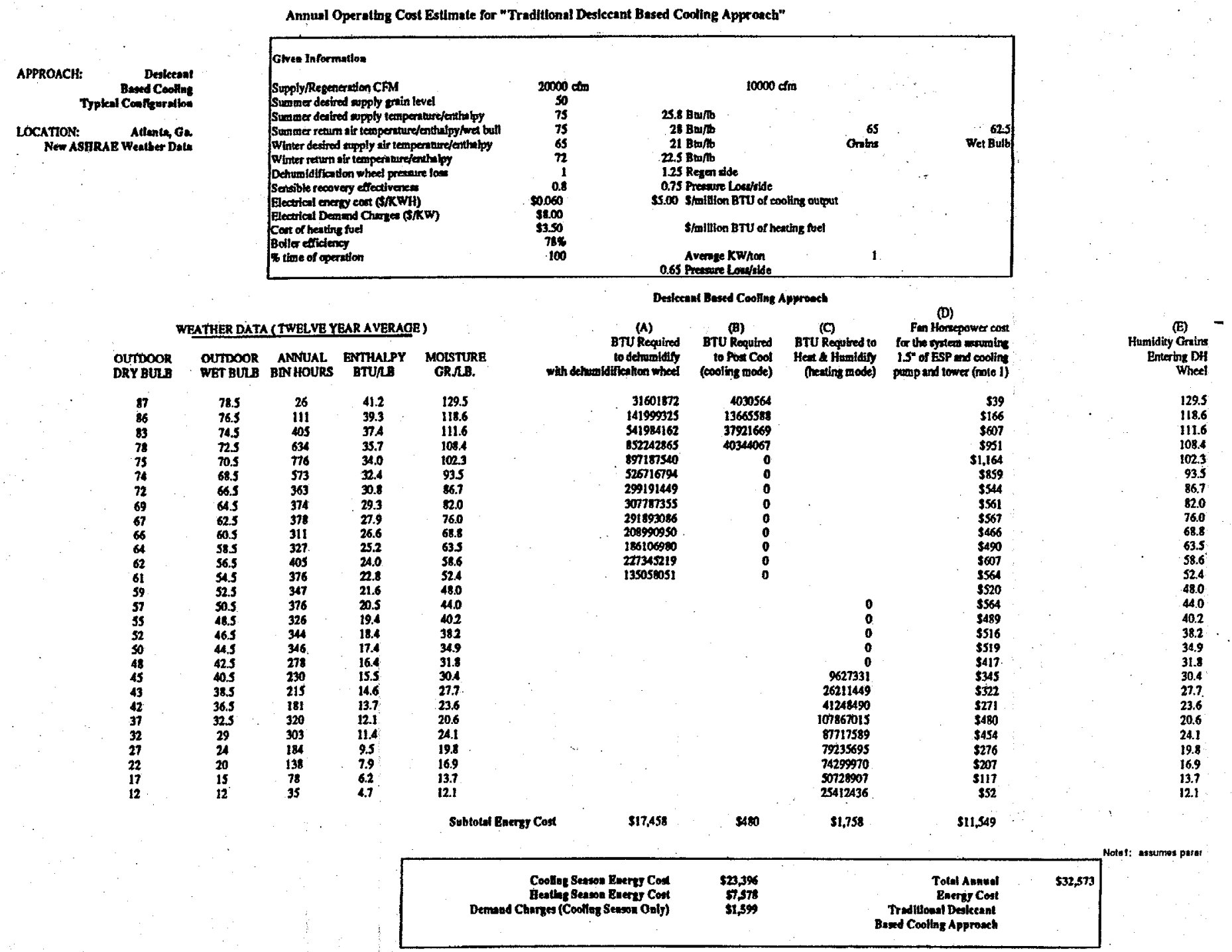




\begin{tabular}{|c|c|c|c|c|c|c|c|c|}
\hline $\begin{array}{c}\text { Tempenture } \\
\text { Emerthe DH } \\
\text { Wheel }\end{array}$ & $\begin{array}{c}\text { Entulpy } \\
\text { Enterng DH } \\
\text { Wheel }\end{array}$ & 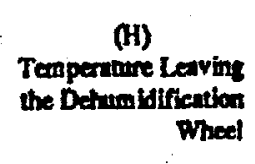 & 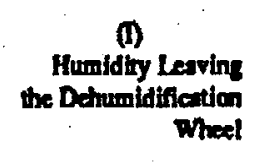 & $\begin{array}{c}\text { (D) } \\
\text { Regenteralon } \\
\text { Terppasture } \\
\text { Rogutred }\end{array}$ & 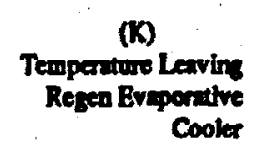 & $\begin{array}{c}\text { Tampentiure } \\
\text { To Regeneration } \\
\text { Coll }\end{array}$ & 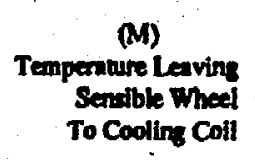 & $\begin{array}{c}\text { N } \\
\text { Enthralpy } \\
\text { Leaving Sendible } \\
\text { Wheel }\end{array}$ \\
\hline 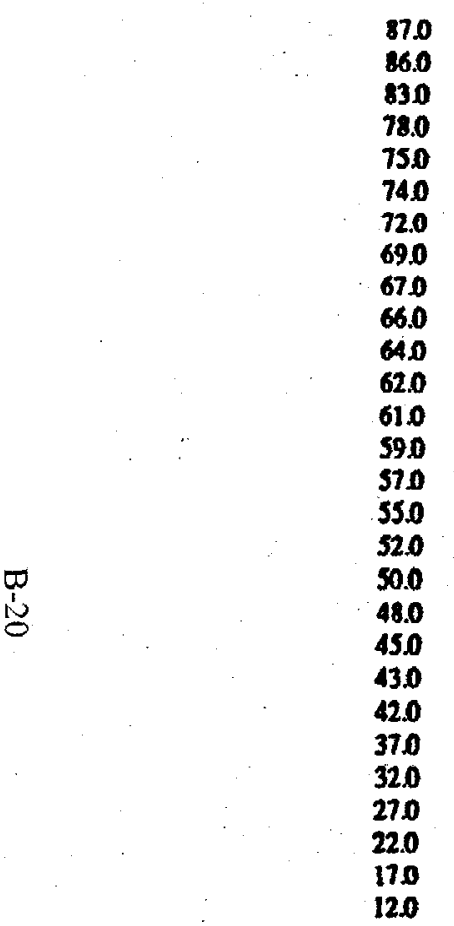 & 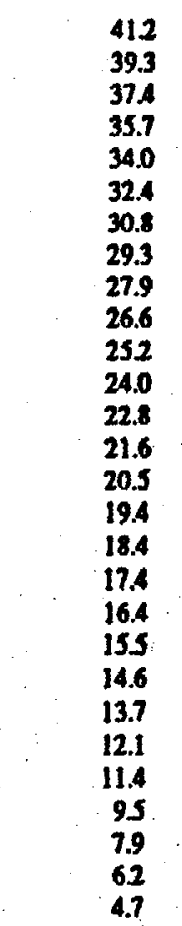 & $\begin{array}{l}155.9 \\
148.5 \\
141.7 \\
13.7 .7 \\
125.2 \\
115.2 \\
10.4 \\
101.3 \\
98.7 \\
88.5 \\
87.7 \\
75.3 \\
67.5\end{array}$ & $\begin{array}{l}50 \\
55 \\
50 \\
50 \\
50 \\
50 \\
50 \\
50 \\
50 \\
50 \\
50 \\
50 \\
50\end{array}$ & $\begin{array}{l}250 \\
250 \\
250 \\
245 \\
210 \\
190 \\
175 \\
170 \\
160 \\
145 \\
130 \\
125 \\
100\end{array}$ & $\begin{array}{l}63.8 \\
63.8 \\
63.8 \\
638.8 \\
63.8 \\
63.8 \\
63.8 \\
63.8 \\
63.8 \\
63.8 \\
63.8 \\
63.8 \\
63.8\end{array}$ & $\begin{array}{r}1375 \\
131.5 \\
126.1 \\
120.1 \\
112.9 \\
112.9 \\
109.9 \\
98.7 \\
99.8 \\
985 \\
82.8 \\
773 \\
73.0 \\
66.7\end{array}$ & $\begin{array}{l}82 \\
81 \\
79 \\
78 \\
76 \\
74 \\
72 \\
71 \\
70 \\
69 \\
67 \\
66 \\
70 \\
69 \\
69 \\
69 \\
68 \\
68 \\
67 \\
67 \\
66 \\
66 \\
65 \\
64 \\
63 \\
62 \\
62 \\
60\end{array}$ & $\begin{array}{l}24.9 \\
24.1 \\
23.4 \\
222.7 \\
22.3\end{array}$ \\
\hline
\end{tabular}


Annual Operating Cost Estimate for "Traditional Desiccant Based Cooling Approach"

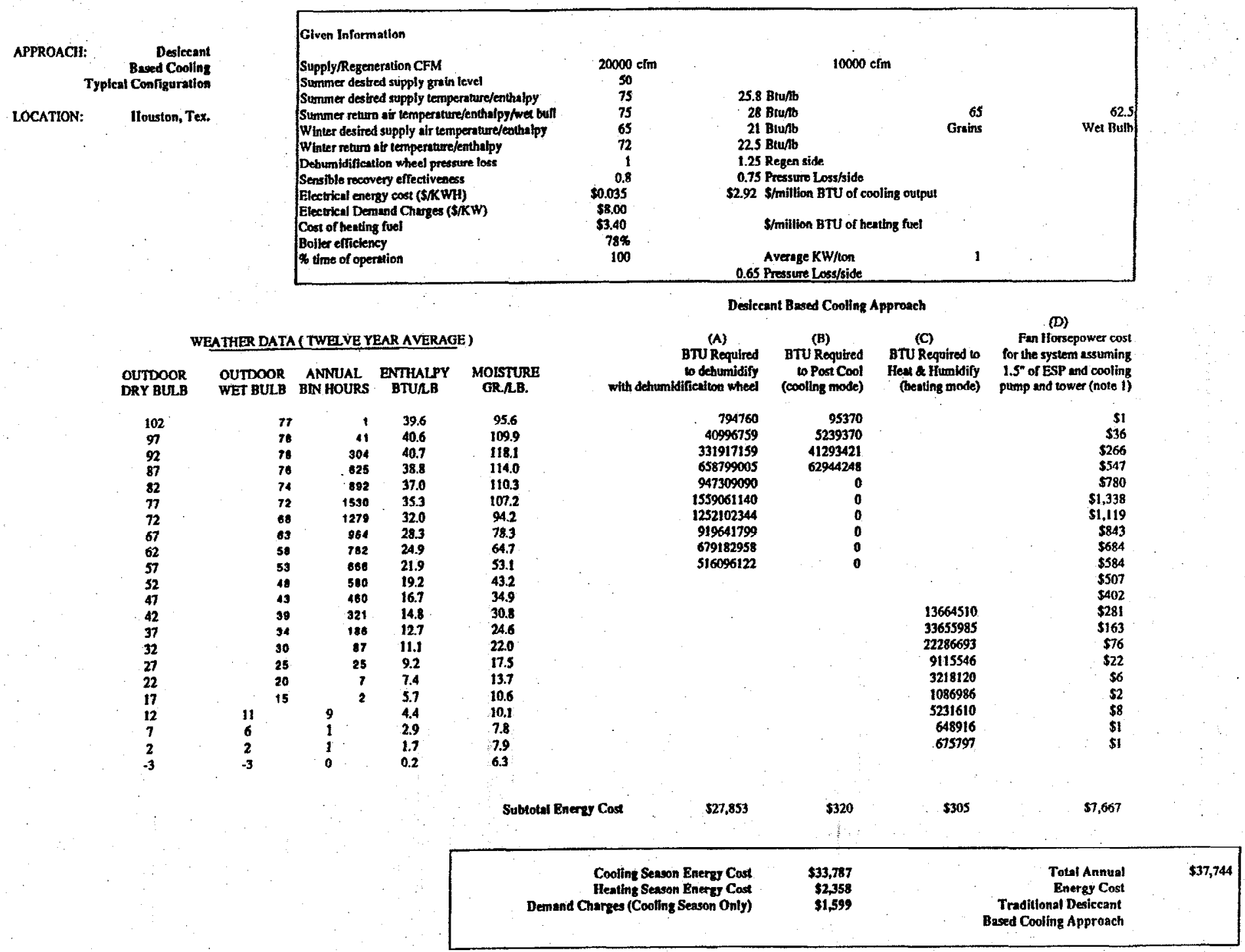




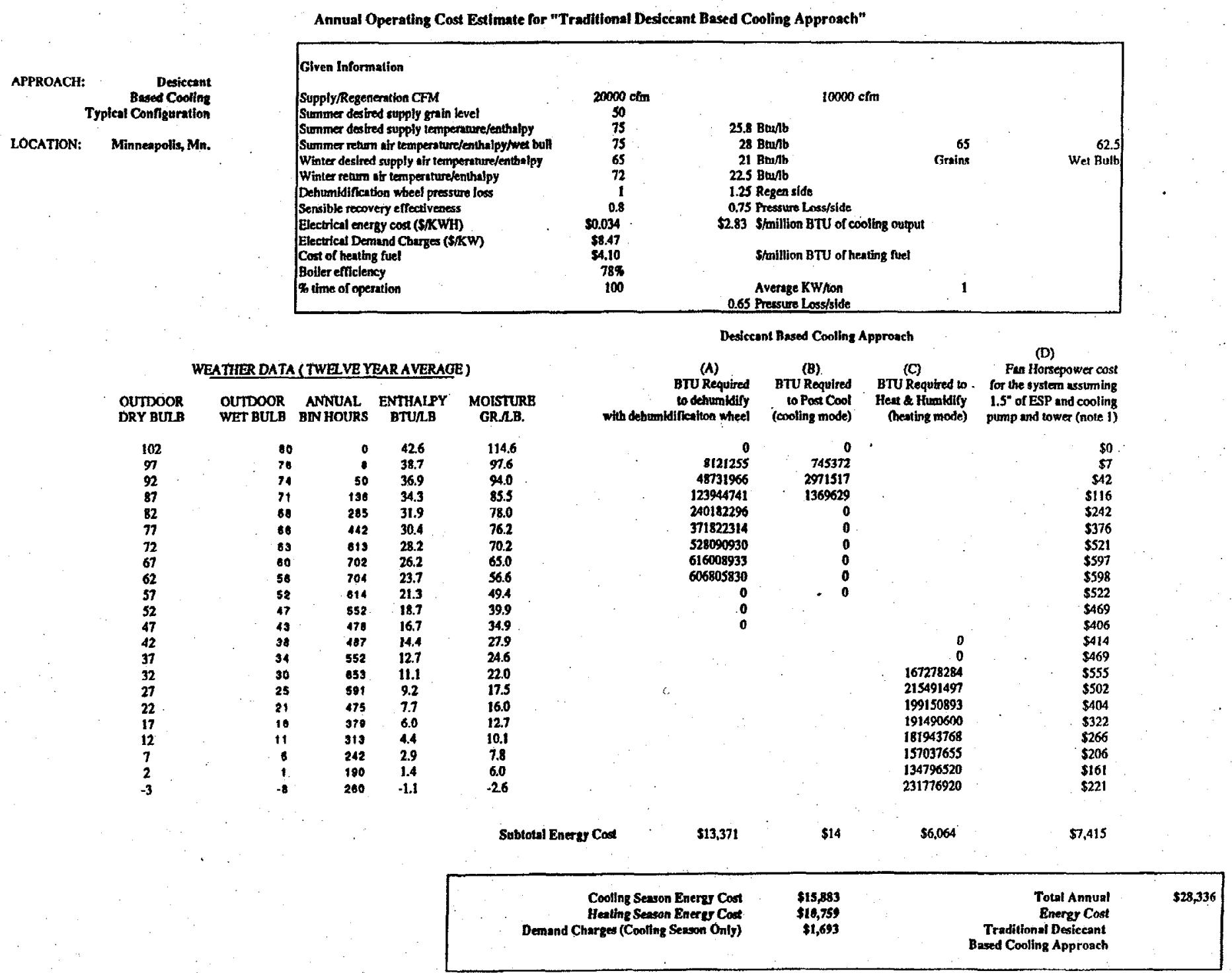




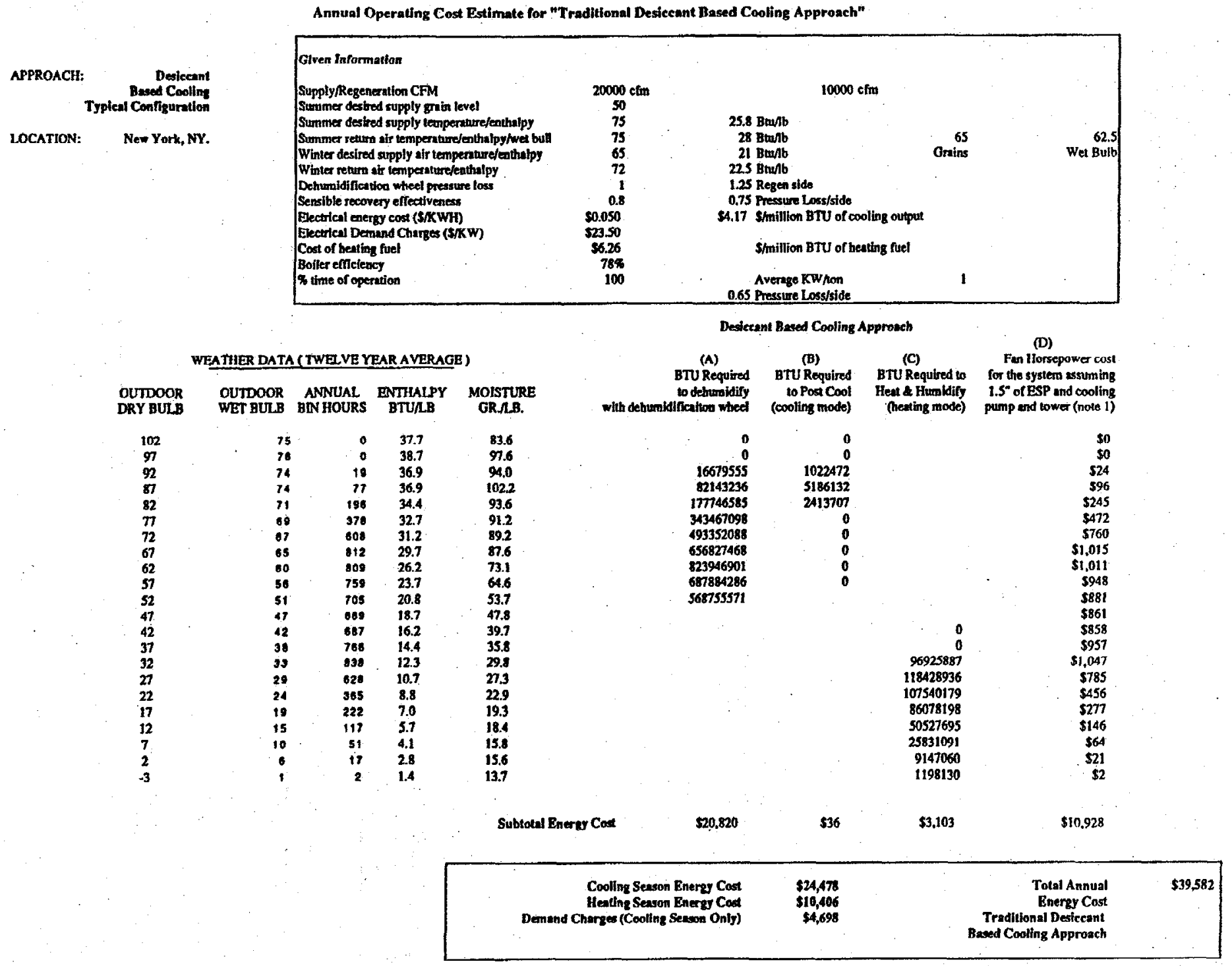


Annual Operating Cost Estimate for "Traditional Desiccant Based Cooling Approach"

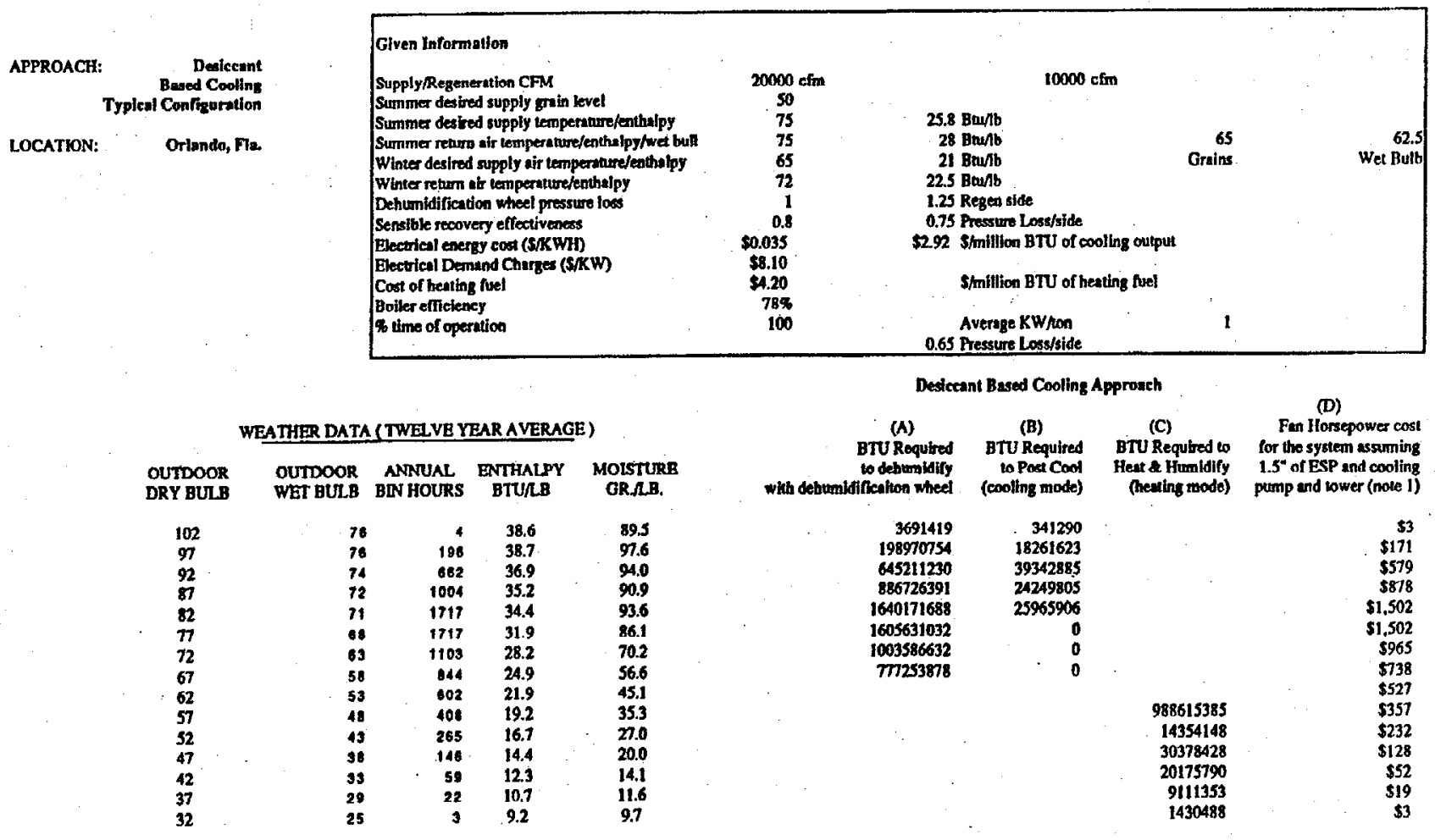

$\begin{array}{lllllll}\text { Sublowl Enery Cost } & \$ 36,407 & \$ 315 & \$ 4,469 & \$ 7,656\end{array}$

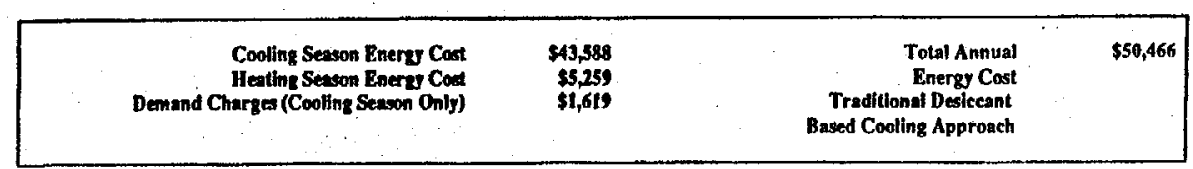




\section{APPENDIX C}

MODELED ENERGY COSTS FOR SELECTED CITIES AT DIFFERENT LEVELS OF DEHUMIDIFICATION 


\section{Case 1}

\section{Estimated Energy Consumption by Preconditioning Approach for Various Cities}

\section{Conditions: Case 1}

- Provide 7,500 cfm of preconditioned outdoor air at 50 grains, (a dewpoint of 48 degrees) at a temperature between 65 and 75 degrees

- Energy costs at $\$ .06 / \mathrm{kwh}$ utilization, $\$ 8 / \mathrm{KW}$ demand and gas at $\$ .48 /$ therm

- Hours of operation used as shown, either continuous or $12 \mathrm{~h} /$ day, 5 days/week.

\begin{tabular}{|c|c|c|c|c|c|c|c|c|c|c|c|c|}
\hline \multirow{2}{*}{$\begin{array}{l}\text { Preconditioning } \\
\text { System Approach }\end{array}$} & \multicolumn{2}{|c|}{ Atlanta } & \multicolumn{2}{|c|}{ Houston } & \multicolumn{2}{|c|}{ Los Angeles } & \multicolumn{2}{|c|}{ Minneapolis } & \multicolumn{2}{|c|}{ New York } & \multicolumn{2}{|c|}{ Orlando } \\
\hline & $\begin{array}{l}24 h \\
7 \text { days }\end{array}$ & $\begin{array}{l}12 \mathrm{~h} \\
5 \text { days }\end{array}$ & $\begin{array}{l}24 \mathrm{~h} \\
7 \text { days }\end{array}$ & $\begin{array}{l}12 \mathrm{~h} \\
5 \text { days }\end{array}$ & $\begin{array}{l}24 \mathrm{~h} \\
7 \text { days }\end{array}$ & $\begin{array}{l}12 \mathrm{~h} \\
5 \text { days }\end{array}$ & $\begin{array}{l}24 \mathrm{~h} \\
7 \text { days }\end{array}$ & $\begin{array}{l}12 \mathrm{~h} \\
5 \text { days }\end{array}$ & $\begin{array}{c}24 \mathrm{~h} \\
7 \text { days }\end{array}$ & $\begin{array}{l}12 \mathrm{~h} \\
5 \text { days }\end{array}$ & $\begin{array}{l}24 \mathrm{~h} \\
7 \text { days }\end{array}$ & $\begin{array}{l}12 \mathrm{~h} \\
5 \text { days }\end{array}$ \\
\hline Conventional Cooling w/Reheat & $\$ 21,818$ & $\$ 11,269$ & $\$ 29,090$ & $\$ 15,127$ & $\$ 13,227$ & $\$ 6,878$ & $\$ 21,640$ & $\$ 11,253$ & $\$ 20,115$ & $\$ 14,081$ & $\$ 28,810$ & $\$ 14,981$ \\
\hline $\begin{array}{l}\text { Conventional Cooling w/Run- } \\
\text { Around Recovery }\end{array}$ & $\$ 15,790$ & $\$ 8,113$ & $\$ 20,370$ & $\$ 8,759$ & $\$ 10,580$ & $\$ 4,549$ & $\$ 18,730$ & $\$ 8,054$ & $\$ 17,097$ & $\$ 8,719$ & $\$ 19,390$ & $\$ 8,338$ \\
\hline $\begin{array}{l}\text { Total Energy Wheel w/Cooling \& } \\
\text { Reheat }\end{array}$ & $\$ 16,142$ & $\$ 8,058$ & $\$ 20,390$ & $\$ 9,991$ & $\$ 9,390$ & $\$ 4,601$ & $\$ 11,980$ & $\$ 5,870$ & $\$ 12,070$ & $\$ 8,208$ & $\$ 21,210$ & $\$ 10,393$ \\
\hline Dual-Wheel Total Energy Recovery & $\$ 10,098$ & $\$ 5,323$ & $\$ 12,280$ & $\$ 6,508$ & $\$ 7,150$ & $\$ 3,790$ & $\$ 8,670$ & $\$ 4,595$ & $\$ 8,290$ & $\$ 5,803$ & $\$ 13,290$ & $\$ 7,044$ \\
\hline $\begin{array}{l}\text { Dual-Wheel } \quad \text { Desiccant-Based } \\
\text { w/Post Cooling }\end{array}$ & $\$ 16,125$ & $\$ 5,810$ & $\$ 24,920$ & $\$ 6,095$ & $\$ 12,350$ & $\$ 3,239$ & $\$ 15,080$ & $\$ 4,825$ & $\$ 14,750$ & $\$ 8,343$ & $\$ 22,025$ & $\$ 7,813$ \\
\hline $\begin{array}{l}\text { Desiccant Dehumidification--Total } \\
\text { Recovery Hybrid }\end{array}$ & $\$ 14,250$ & $\$ 5,280$ & $\$ 22,010$ & $\$ 4,425$ & $\$ 10,910$ & $\$ 3,786$ & $\$ 13,330$ & $\$ 3,574$ & $\$ 10,820$ & $\$ 5,798$ & $\$ 20,340$ & $\$ 5,660$ \\
\hline $\begin{array}{l}\text { Dual-Wheel DBC--Total Recovery } \\
\text { Hybrid }\end{array}$ & $\$ 10,780$ & $\$ 4,562$ & $\$ 13,658$ & $\$ 4,205$ & $\$ 7,835$ & $\$ 3,726$ & $\$ 9,690$ & $\$ 3,520$ & $\$ 8,190$ & $\$ 6,859$ & $\$ 12,560$ & $\$ 5,238$ \\
\hline
\end{tabular}




\section{Estimated Energy Consumption by Preconditioning Approach for Various Cities \\ Conditions: Case 2}

- Provide 7,500 cfm of preconditioned outdoor air at 65 grains, (a 55 degree dewpoint) at a temperature between 65 and 75 degrees

- Energy costs at $\$ .06 / \mathrm{kwh}$ utilization, $\$ 8 / \mathrm{KW}$ demand and gas at $\$ .48 /$ therm

- Hours of operation used as shown, either continuous or $12 \mathrm{~h} / \mathrm{day}, 5$ days/week

\begin{tabular}{|c|c|c|c|c|c|c|c|c|c|c|c|c|}
\hline \multirow{2}{*}{$\begin{array}{l}\text { Preconditioning } \\
\text { System Approach }\end{array}$} & \multicolumn{2}{|c|}{ Atlanta } & \multicolumn{2}{|c|}{ Houston } & \multicolumn{2}{|c|}{ Los Angeles } & \multicolumn{2}{|c|}{ Minneapolis } & \multicolumn{2}{|c|}{ New York } & \multicolumn{2}{|c|}{ Orlando } \\
\hline & $\begin{array}{l}24 \mathrm{~h} \\
7 \text { days }\end{array}$ & $\begin{array}{l}12 \mathrm{~h} \\
5 \text { days }\end{array}$ & $\begin{array}{l}24 h \\
7 \text { days }\end{array}$ & $\begin{array}{c}12 \mathrm{~h} \\
5 \text { days }\end{array}$ & $\begin{array}{l}24 h \\
7 \text { days }\end{array}$ & $\begin{array}{c}12 \mathrm{~h} \\
5 \text { days }\end{array}$ & $\begin{array}{l}24 \mathrm{~h} \\
7 \text { days }\end{array}$ & $\begin{array}{c}12 \mathrm{~h} \\
5 \text { days }\end{array}$ & $\begin{array}{l}24 \mathrm{~h} \\
7 \text { days }\end{array}$ & $\begin{array}{c}12 \mathrm{~h} \\
5 \text { days }\end{array}$ & $\begin{array}{l}24 h \\
7 \text { days }\end{array}$ & $\begin{array}{c}12 \mathrm{~h} \\
5 \text { days }\end{array}$ \\
\hline Conventional Cooling w/Reheat & $\$ 16,938$ & $\$ 11,269$ & $\$ 22,374$ & $\$ 11,634$ & $\$ 9,233$ & $\$ 4,801$ & $\$ 18,155$ & $\$ 9,441$ & $\$ 16,385$ & $\$ 11 ; 470$ & $\$ 21,290$ & $\$ 11,071$ \\
\hline $\begin{array}{l}\text { Conventional Cooling w/Run-around } \\
\text { Recovery }\end{array}$ & $\$ 13,527$ & $\$ 8,113$ & $\$ 16,109$ & $\$ 6,927$ & $\$ 7,202$ & $\$ 3,097$ & $\$ 16,632$ & $\$ 7,152$ & $\$ 14,747$ & $\$ 7,521$ & $\$ 15,896$ & $\$ 6,835$ \\
\hline $\begin{array}{l}\text { Total Energy Wheel w/Cooling \& } \\
\text { Reheat }\end{array}$ & $\$ 11,262$ & $\$ 8,058$ & $\$ 15,214$ & $\$ 7,455$ & $\$ 6,135$ & $\$ 3,006$ & $\$ 8,976$ & $\$ 4,398$ & $\$ 9,012$ & $\$ 6,128$ & $\$ 15,062$ & $\$ 7,380$ \\
\hline Dual-wheel Total Energy Recovery & $\$ 7,336$ & $\$ 5,323$ & $\$ 8,430$ & $\$ 4,468$ & $\$ 4,905$ & $\$ 2,600$ & $\$ 6,812$ & $\$ 3,610$ & $\$ 6,155$ & $\$ 4,309$ & $\$ 9,161$ & $\$ 4,855$ \\
\hline $\begin{array}{l}\text { Dual-wheel Desiccant Based (DBC) } \\
\text { w/Post Cooling }\end{array}$ & $\$ 14,880$ & $\$ 5,810$ & $\$ 22,988$ & $\$ 6,095$ & $\$ 11,398$ & $\$ 3,239$ & $\$ 12,642$ & $\$ 4,825$ & $\$ 13,619$ & $\$ 8,343$ & $\$ 20,324$ & $\$ 7,813$ \\
\hline $\begin{array}{l}\text { Desiccant Dehumidification - Total } \\
\text { Recovery Hybrid }\end{array}$ & $\$ 10,983$ & $\$ 5,280$ & $\$ 15,595$ & $\$ 4,425$ & $\$ 6,435$ & $\$ 3,786$ & $\$ 8,250$ & $\$ 3,574$ & $\$ 7,862$ & $\$ 5,798$ & $\$ 14,125$ & $\$ 5,660$ \\
\hline $\begin{array}{l}\text { Dual-wheel DBC - Total Recovery } \\
\text { Hybrid }\end{array}$ & $\$ 7,636$ & $\$ 4,562$ & $\$ 8,905$ & $\$ 4,205$ & $\$ 5,469$ & $\$ 3,726$ & $\$ 6,610$ & $\$ 3,520$ & $\$ 6,280$ & $\$ 6,859$ & $\$ 8,100$ & $\$ 5,238$ \\
\hline
\end{tabular}




\section{Case 3}

\section{Estimated Energy Consumption by Preconditioning Approach for Various Cities}

\section{Conditions: Case 3}

- Provide 7,500 cfm of preconditioned outdoor air at 45 grains, (a 45 degree dewpoint), at a temperature between 65 and 75 degrees

- Energy costs at $\$ .06 / \mathrm{kwh}$ utilization, $\$ 8 / \mathrm{KW}$ demand and gas at $\$ .48 /$ therm

- Hours of operation used as shown, either continuous or $12 \mathrm{~h} /$ day, 5 days/week

\begin{tabular}{|c|c|c|c|c|c|c|c|c|c|c|c|c|}
\hline \multirow{2}{*}{$\begin{array}{l}\text { Preconditioning } \\
\text { System Approach }\end{array}$} & \multicolumn{2}{|c|}{ Atlanta } & \multicolumn{2}{|c|}{ Houston } & \multicolumn{2}{|c|}{ Los Angeles } & \multicolumn{2}{|c|}{ Minneapolis } & \multicolumn{2}{|c|}{ New York } & \multicolumn{2}{|c|}{ Orlando } \\
\hline & $\begin{array}{l}24 \mathrm{~h} \\
7 \text { days }\end{array}$ & $\begin{array}{l}12 \mathrm{~h} \\
5 \text { days }\end{array}$ & $\begin{array}{c}24 \mathrm{~h} \\
7 \text { days }\end{array}$ & $\begin{array}{c}24 \mathrm{~h} \\
7 \text { days }\end{array}$ & $\begin{array}{c}24 \mathrm{~h} \\
7 \text { days }\end{array}$ & $\begin{array}{c}12 \mathrm{~h} \\
5 \text { days }\end{array}$ & $\begin{array}{c}24 \mathrm{~h} \\
7 \text { days }\end{array}$ & $\begin{array}{l}12 \mathrm{~h} \\
5 \text { days }\end{array}$ & $\begin{array}{l}24 \mathrm{~h} \\
7 \text { days }\end{array}$ & $\begin{array}{c}12 \mathrm{~h} \\
5 \text { days }\end{array}$ & $\begin{array}{c}24 \mathrm{~h} \\
7 \text { days }\end{array}$ & $\begin{array}{c}12 \mathrm{~h} \\
5 \text { days }\end{array}$ \\
\hline Conventional Cooling w/Reheat & $\$ 26,946$ & $\$ 11,269$ & $\$ 35,980$ & $\$ 18,710$ & $\$ 17,480$ & $\$ 9,090$ & $\$ 25,173$ & $\$ 13,090$ & $\$ 23,670$ & $\$ 16,569$ & $\$ 36,659$ & $\$ 19,063$ \\
\hline $\begin{array}{l}\text { Conventional Cooling w/Run-around } \\
\text { Recovery }\end{array}$ & $\$ 19,142$ & $\$ 8,113$ & $\$ 24,826$ & $\$ 10,675$ & $\$ 12,236$ & $\$ 5,261$ & $\$ 20,411$ & $\$ 8,777$ & $\$ 18,936$ & $\$ 9,657$ & $\$ 23,079$ & $\$ 9,924$ \\
\hline $\begin{array}{l}\text { Total Energy Wheel w/Cooling \& } \\
\text { Reheat }\end{array}$ & $\$ 21,272$ & $\$ 8,058$ & $\$ 29,144$ & $\$ 14,281$ & $\$ 11,190$ & $\$ 5,483$ & $\$ 17,269$ & $\$ 8,462$ & $\$ 16,279$ & $\$ 11,070$ & $\$ 30,129$ & $\$ 14,763$ \\
\hline Dual-wheel Total Energy Recovery & $\$ 12,686$ & $\$ 5,323$ & $\$ 18,820$ & $\$ 9,975$ & $\$ 6,915$ & $\$ 3,665$ & $\$ 10,290$ & $\$ 5,454$ & $\$ 8,995$ & $\$ 6,297$ & $\$ 17,205$ & $\$ 9,119$ \\
\hline $\begin{array}{l}\text { Dual-wheel Desiccant Based (DBC) } \\
\text { w/Post Cooling }\end{array}$ & $\$ 18,750$ & $\$ 5,810$ & $\$ 28,967$ & $\$ 6,095$ & $\$ 14,363$ & $\$ 3,239$ & $\$ 17,545$ & $\$ 4,825$ & $\$ 17,160$ & $\$ 8,343$ & $\$ 25,610$ & $\$ 7,813$ \\
\hline $\begin{array}{l}\text { Desiccant Dehumidification - Total } \\
\text { Recovery Hybrid }\end{array}$ & $\$ 15,579$ & $\$ 5,280$ & $\$ 24,062$ & $\$ 4,425$ & $\$ 11,790$ & $\$ 3,786$ & $\$ 14 ; 580$ & $\$ 3,574$ & $\$ 11,830$ & $\$ 5,798$ & $\$ 22,625$ & $\$ 5,660$ \\
\hline $\begin{array}{l}\text { Dual-wheel DBC - Total Recovery } \\
\text { Hybrid }\end{array}$ & $\$ 11,250$ & $\$ 4,562$ & $\$ 14,846$ & $\$ 4,205$ & $\$ 8,514$ & $\$ 3,726$ & $\$ 10,529$ & $\$ 3,520$ & $\$ 8,655$ & $\$ 6,859$ & $\$ 13,650$ & $\$ 5,238$ \\
\hline
\end{tabular}




\section{Case 4}

Estimated Energy Consumption by Preconditioning Approach for Various Cities

Conditions: Case 4

- Provide 7,500 cfm of preconditioned outdoor air at 50 grains, at a temperature between 65 and 75 degrees

- Energy costs used are 1994 actual rates for the cities listed, electric rates based on acommercial customer with a 500+ $\mathrm{KW}$ demand

- See City Selection section and associated energy cost data

\begin{tabular}{|c|c|c|c|c|c|c|c|c|c|c|c|c|}
\hline \multirow{2}{*}{$\begin{array}{l}\text { Preconditioning } \\
\text { System Approach }\end{array}$} & \multicolumn{2}{|c|}{ Atlanta } & \multicolumn{2}{|c|}{ Houston } & \multicolumn{2}{|c|}{ Los Angeles } & \multicolumn{2}{|c|}{ Minneapolis } & \multicolumn{2}{|c|}{ New York } & \multicolumn{2}{|c|}{ Orlando } \\
\hline & $\begin{array}{l}24 \mathrm{~h} \\
7 \text { days }\end{array}$ & $\begin{array}{c}12 \mathrm{~h} \\
5 \text { days }\end{array}$ & $\begin{array}{l}24 h \\
7 \text { days }\end{array}$ & $\begin{array}{c}12 \mathrm{~h} \\
5 \text { days }\end{array}$ & $\begin{array}{l}24 \mathrm{~h} \\
7 \text { days }\end{array}$ & $\begin{array}{c}12 \mathrm{~h} \\
5 \text { days }\end{array}$ & $\begin{array}{c}24 \mathrm{~h} \\
7 \text { days }\end{array}$ & $\begin{array}{l}12 h \\
5 \text { days }\end{array}$ & $\begin{array}{l}24 \mathrm{~h} \\
7 \text { days }\end{array}$ & $\begin{array}{c}12 \mathrm{~h} \\
5 \text { days }\end{array}$ & $\begin{array}{c}24 \mathrm{~h} \\
7 \text { days }\end{array}$ & $\begin{array}{l}12 \mathrm{~h} \\
5 \text { days }\end{array}$ \\
\hline Conventional Cooling w/Reheat & $\$ 21,818$ & $\$ 11,269$ & $\$ 18,450$ & $\$ 9,594$ & $\$ 9,507$ & $\$ 4,944$ & $\$ 16,920$ & $\$ 8,798$ & $\$ 26,963$ & $\$ 18,874$ & $\$ 19,830$ & $\$ 10,312$ \\
\hline $\begin{array}{l}\text { Conventional Cooling w/Run-around } \\
\text { Recovery }\end{array}$ & $\$ 15,790$ & $\$ 8,113$ & $\$ 13,844$ & $\$ 5,953$ & $\$ 7,555$ & $\$ 3,249$ & $\$ 15,291$ & $\$ 6,575$ & $\$ 20,976$ & $\$ 10,698$ & $\$ 11,479$ & $\$ 4,936$ \\
\hline $\begin{array}{l}\text { Total Energy Wheel w/Cooling \& } \\
\text { Reheat }\end{array}$ & $\$ 16,142$ & $\$ 8,058$ & $\$ 14,673$ & $\$ 7,190$ & $\$ 12,678$ & $\$ 6,212$ & $\$ 9,452$ & $\$ 4,631$ & $\$ 15,651$ & $\$ 10,643$ & $\$ 15,605$ & $\$ 7,646$ \\
\hline Dual-wheel Total Energy Recovery & $\$ 10,098$ & $\$ 5,323$ & $\$ 7,762$ & $\$ 4,114$ & $\$ 5,717$ & $\$ 3,030$ & $\$ 5,942$ & $\$ 3,149$ & $\$ 10,100$ & $\$ 7,070$ & $\$ 8,328$ & $\$ 4,414$ \\
\hline $\begin{array}{l}\text { Dual-wheel Desiccant Based (DBC) } \\
\text { w/Post Cooling }\end{array}$ & $\$ 13,298$ & $\$ 5,810$ & $\$ 14,154$ & $\$ 6,095$ & $\$ 11,774$ & $\$ 3,239$ & $\$ 10,626$ & $\$ 4,825$ & $\$ 14,843$ & $\$ 8,343$ & $\$ 18,925$ & $\$ 7,813$ \\
\hline $\begin{array}{l}\text { Desiccant Dehumidification - Total } \\
\text { Recovery Hybrid }\end{array}$ & $\$ 12,792$ & $\$ 5,280$ & $\$ 10,365$ & $\$ 4,425$ & $\$ 8,571$ & $\$ 3,786$ & $\$ 7,983$ & $\$ 3,574$ & $\$ 13,327$ & $\$ 5,798$ & $\$ 13,777$ & $\$ 5,660$ \\
\hline $\begin{array}{l}\text { Dual-wheel DBC - Total Recovery } \\
\text { Hybrid }\end{array}$ & $\$ 9,474$ & $\$ 4,562$ & $\$ 9,091$ & $\$ 4,205$ & $\$ 7,517$ & $\$ 3,726$ & $\$ 7,001$ & $\$ 3,520$ & $\$ 10,719$ & $\$ 6,859$ & $\$ 11,772$ & $\$ 5,238$ \\
\hline
\end{tabular}



APPENDIX D

SAMPLE CUSTOMER SURVEY SHEET 



\section{Retail Stores (Example)}

\section{Sample application Evaluation Questionnaire:}

The purpose of this questionnaire is to help identify the market need and eventual acceptance of outdoor air, desiccant based, preconditioning approaches. Each application will be assessed using a questionnaire similar to this one, and these questionnaires will be answered internally, by field sales of both Trane and Semco, and by qualified and cooperative consulting engineers and owners.

\section{Sample Questions:}

1) How important is humidity control in this application?
a. Not important
b. Somewhat important
c. Very important

2) In your opinion, it is important to maintain the space relative humidity below the following level during the cooling season for this application?
a. $50 \%$
b. $60 \%$ c. $70 \%$
d. No maximum required

3) In your opinion, it is important to maintain the space relative humidity at at least the following level during the heating season for this application?
a. $50 \%$
b. $30 \%$ c. $20 \%$
d. No minimum required

4) In your opinion, is it important to maintain these levels during evenings and weekends, as well as during the day?
a. Yes
b. No
c. Not applicable

5) What is the percentage of total system airflow that is typically outdoor air in this application?
a. $0-20 \%$
b. $20-30 \%$
c. $30-50 \%$
d. More than $50 \%$

6) In your opinion, when designing for this application for either new construction or renovations, the ASHRAE 62-89 guidelines will be followed, (including the outdoor air 
$\mathrm{cfm} /$ person recommendations and continuous supply of outdoor air) the following percent of the time?
a. More than $75 \%$
b. $50-75 \%$
c. $25-50 \%$
d. less than $25 \%$

7) What type of air conditioning equipment is most often used in this application?
a. Mostly DX
b. Mostly chilled water
c. $50 / 50$

8) Using a 1,2 or 3, rank your impression of the importance of the following criteria as it relates to choosing the HVAC system for this application

( ) First cost

( ) Energy efficiency

( ) Providing environmental control (ie:temperature/humidity control, good IAQ)

9) Based on your experience, what percentage of projects in this application segment offer an exhaust air stream that can be ducted to the preconditioning system or a return air stream from which and exhaust air stream can be accessed for the same purpose?
a. More than $75 \%$
b. $50-75 \%$
c. $25-50 \%$
d. less than $25 \%$

10) Is low cost steam, hot water or other forms of waste heat typically available for desiccant regeneration during the cooling season for this application?
a. Yes
b. No

11) Do significant benefits exist, in your opinion, from maintaining humidity control in this application that would justify a higher first cost for the HVAC system (ie: comfort, reduccd damage to furniture and wall coverings, improved research, dry cooling coils, etc.). If so list the benefit.
a. Yes
b. No

12) Are you aware of the new ASHRAE weather data evaluation that shows a significant increase in the outdoor air peak humidity design conditions?
a. Yes
b. No 
13) Is there a significant benefit to this application to have pollutants that may exist in the outdoor air removed from the outdoor air prior to being introduced into the facility?
a. Yes
b. No

14) If you have had a previous experience with a desiccant wheel system (dehumidification or recovery) how would you rate it? (Only respond to personal experience please).
a. Positive
b. Negative
c. Not applicable 

APPENDIX E

FINAL MARKET SEGMENT ANALYSIS SHEETS 



\section{Final Market Segment Analysis: Office Buildings}

Benefits provided by preconditioning of outdoor air loads

Potential market for this application using some type of preconditioning (Estimates for 1996)

Total outdoor air CFM for segment
The increased outdoor air loads associated with ASHRAE 62-89 can increase project first cost and operating cost significantly. Preconditioning can cut demand charges significantly, reduce energy consumption, provide acceptable humidity control, and help conventional heat pumps and DX units perform with constant outdoor air loads. Removing outdoor air pollutants and providing low duct RH may be significant benefits in the future.

$\$ 127,755,000$ per year ${ }^{*}$

$56,000,000$ CFM

\begin{tabular}{|c|c|c|c|}
\hline Preconditioning Approach & $\begin{array}{c}\text { Rank Likelihood } \\
\text { of Utilization }\end{array}$ & $\begin{array}{c}\text { \% of Estimated } \\
\text { Available Market }\end{array}$ & $\begin{array}{c}\text { \$ Estimated Market } \\
\text { Potential }\end{array}$ \\
\hline Conventional Cooling w/ Reheat & 1 & 65 & $55,575,000$ \\
Conventional w/ Heat Pipe & 3 & 7 & $10,395,000$ \\
Conventional with Total Recovery & 2 & 25 & $50,625,000$ \\
Total Recovery Dual Wheel & 6 & 1 & $3,600,000$ \\
DBC approach & 5 & 2 & $7,560,000$ \\
$\begin{array}{c}\text { Hybrid Total Recovery } \\
\text { Desiccant Dehumidification approach }\end{array}$ & 4 & 0 & \\
$\begin{array}{c}\text { Hybrid Total Recovery } \\
\text { DBC approach }\end{array}$ & 7 & & \\
\hline
\end{tabular}

- Conclusions and Comments Regarding the Desiccant Based Preconditioning Market:

Of the 28,000 buildings constructed each year, only 200 are 4 stories or greater. Only these 200 would likely prove opportunities for $\mathrm{DBC}$ preconditioning. Gas is seldom available on rooftops of high-rise facilities. Unless dry ductwork and coils are mandated, conventional cooling/recovery will likely be used for this application. The exception will be buildings located were demand charges are high, where an exhaust air path is unobtainable, where the existing cooling capacity is fully utilized and where outdoor air flow needs to be increased (i.e. accommodate ASHRAE 62-1989). Offices designed with ice storage and super cold air distribution are viable applications for hybrid recovery/desiccant dehumidification. When ASHRAE-62-1989 is integrated into an office environment, even for small office buildings, non-regenerated desiccant total energy recovery wheels appears by far the method of choice 


\section{Final Market Segment Analysis: Hospital Operating Rooms}

Benefits provided by preconditioning of outdoor air loads

Potential market for this application using some type of preconditioning (Estimates for 1996)

Total outdoor air CFM for segment
Operating rooms need to have humidity controlled for antiseptic reasons. With the advent of AIDS, more protective gear is worn by the medical staff. This, in conjunction with heat generated by medical machinery, require conditions of 65-68 degrees for comfort. Relative humidity must still be controlled at approximately $50 \% \mathrm{RH}$ which is not easily accomplished with conventional refrigeration

$$
\$ 10,344,000 \text { per year* }
$$

* (assumes 30\% of market needs dew-points below 50 degrees)

$$
4,800,000 \mathrm{CFM}
$$

\begin{tabular}{|c|c|c|c|}
\hline Preconditioning Approach & $\begin{array}{c}\text { Rank Likelihood } \\
\text { of Utilization }\end{array}$ & $\begin{array}{c}\% \text { of Estimated } \\
\text { Availablc Markct }\end{array}$ & $\begin{array}{c}\text { \$ Estimaled Market } \\
\text { Potential }\end{array}$ \\
\hline Conventional Cooling w/ Reheat & 1 & 50 & $\$ 2,280,000$ \\
\hline Conventional w/ Heat Pipe & 5 & 0 & \\
\hline Conventional with Total Recovery & 2 & 20 & $\$ 2,160,000$ \\
\hline Total Recovery Dual Wheel & 7 & 0 & \\
\hline DBC approach & 4 & 15 & $\$ 2,880,000$ \\
\hline $\begin{array}{c}\text { Hybrid Total Recovery } \\
\text { Desiccant Dehumidification approach }\end{array}$ & 3 & 15 & $\$ 3,024,000$ \\
\hline $\begin{array}{l}\text { Hybrid Total Recovery } \\
\text { DBC approach }\end{array}$ & 6 & 0 & \\
\hline
\end{tabular}

- Conclusions and Comments Regarding the Desiccant Based Preconditioning Market:

The driver causing the hospital to maintain humidity conditions is the surgeon, therefore significant. The surgeons insurance, liability and reputation may ride on controlling space conditions. Awareness of this appears is on the rise. Hospital facilities also typically have low cost steam available during the cooling season for desiccant regeneration. This is not a cost sensitive market and would likely pay a premium for both environmental control and energy efficiency. The requirements of the desiccant equipment would ideally accommodate high efficiency filters, heating/cooling coils, dual wall institutional construction, high pressure blowers and controls. Key benefits offered by desiccants include desired humidity control, dry ductwork, dry final filters (a big problem for hospital ORs). Hours of operation are continuous so energy savings analyses are maximized. 


\section{Final Market Segment Analysis: School Classrooms}

Benefits provided by preconditioning of outdoor air loads

Potential market for this application using some type of preconditioning (Estimates for 1996)

Total outdoor air CFM for segment
The increased outdoor air loads associated with ASHRAE 62-89 can increase project first cost and operating cost significantly. Preconditioning can cut demand charges and energy consumption, assure acceptable humidity control, and help conventional heat pumps and DX units perform with constant outdoor air loads. Neutral temperature, dry air is beneficial in classrooms due to the changing load associated with people and desire to use packaged equipment controlled via temperature in each classroom.

$\$ 222,979,500$ per year*

* (assumes all buildings comply with ASHRAE 62-89)

\begin{tabular}{|c|c|c|c|}
\hline Preconditioning Approach & $\begin{array}{c}\text { Rank Likelihood } \\
\text { of Utilization }\end{array}$ & $\begin{array}{c}\% \text { of Estimated } \\
\text { Available Market }\end{array}$ & $\begin{array}{c}\text { \$ Estimated Market } \\
\text { Potential } \\
\end{array}$ \\
\hline Conventional Cooling w/ Reheat & 2 & 50 & $\$ 59,137,500$ \\
\hline Conventional w/ Heat Pipe & 3 & 10 & $\$ 20,542,500$ \\
\hline Conventional with Total Recovery & 1 & 20 & $\$ 56,025,000$ \\
\hline Tolal Recovery Dual Wheel & 4 & 15 & $\$ 61,627,500$ \\
\hline DBC approach & 6 & 2 & $\$ 9,960,000$ \\
\hline $\begin{array}{l}\text { Hybrid Total Recovery } \\
\text { Desiccant Dehumidification approach }\end{array}$ & 5 & 3 & $\$ 15,687,000$ \\
\hline $\begin{array}{l}\text { Hybrid Total Recovery } \\
\text { DBC approach }\end{array}$ & 7 & 0 & \\
\hline
\end{tabular}

- Conclusions and Comments Regarding the Desiccant Based Preconditioning Market:

Due to the high exchange rate of outdoor air in schools, there is almost always access to an exhaust air path. Since packaged cooling equipment is most often used, humidity control is critical in humid environments. The dew points required by a school project are easily obtained with conventional cooling, controlling the humidity is the problem. Regenerated desiccant systems provide dry, warm air to the school (ie: $90-95$ degrees at 50 grains on a typical design day). The dual wheel energy recovery approach provides the same dehumidification yet at the desired 68 degrees, allowing the conventional HVAC system to be down-sized It also provides heating mode recovery and humidification which is important. In non-humid climates conventional single wheel desiccant based total recovery is most appropriate. Maintenance in schools is limited, evaporative coolers and gas bumers are viewed as too troublesome. If schools embrace the benefits of dry coils, regenerated desiccant wheel systems will be feasible. 


\section{Final Market Segment Analysis: Nursing Homes/Hospitals}

Benefits provided by preconditioning of outdoor air loads

Potential market for this application using some type of preconditioning (Estimates for 1996)

Total outdoor air CFM for segment
Nursing homes and hospital bed areas need large quantities of outdoor air for health and odor maintenance. Preconditioning allows for better humidity control with the use of conventional packaged equipment. Condensate can be reduced or eliminated on the coils and down the duct. Final filters can be kept dry if all of the latent load is handled with the outdoor air. As with hospital operating rooms, the likelihood of reinfection is greatly reduced if space relative humidity is controlled.

$$
\$ 71,802,500 \text { per year }^{*}
$$

* ( assumes all buildings comply with ASHRAE 62-89)

$$
13,750,000 \mathrm{CFM}
$$

\begin{tabular}{|c|c|c|c|}
\hline Preconditioning Approach & $\begin{array}{l}\text { Rank Likelihood } \\
\text { of Utilization }\end{array}$ & $\begin{array}{c}\% \text { of Estimated } \\
\text { Available Market }\end{array}$ & $\begin{array}{c}\text { \$ Estimated Market } \\
\text { Potential }\end{array}$ \\
\hline Conventional Cooling w/ Reheat & 1 & 45 & $16,458,750$ \\
\hline Conventional w/ Heat Pipe & 3 & 15 & $9,528,750$ \\
\hline Conventional with Total Recovery & 2 & 20 & $17,325,000$ \\
\hline Total Recovery Dual Wheel & 4 & 10 & $12,705,000$ \\
\hline DBC approach & 5 & 5 & $7,700,000$ \\
\hline $\begin{array}{c}\text { Hybrid Total Recovery } \\
\text { Desiccant Dehumidification approach }\end{array}$ & 6 & 5 & $8,085,000$ \\
\hline $\begin{array}{l}\text { Hybrid Total Recovery } \\
\text { DBC approach }\end{array}$ & 7 & 0 & \\
\hline
\end{tabular}

- Conclusions and Comments Regarding the Desiccant Based Preconditioning Market:

General hospital and nursing home areas do not have the same stringent humidity requirements as operating rooms. Odors associated with humidity problems, comfort, and dry filters and ductwork are the main drivers for regenerated desiccant systems for this application. Waste steam is often available.

Where an exhaust air path is not availablc and the climate is humid, a good opportunity exists for some type of regenerated desiccant approach. This market is not as cost sensitive as most and maintenance is usually not an impediment. Nursing homes are promising for preconditioning since the occupants like dry, warm air and IAQ is an important factor in deciding on one nursing home over another. 


\section{Final Market Segment Analysis: Research Laboratories}

Benefits provided by preconditioning of outdoor air loads
Research laboratories often require a significant amount of outdoor air to replace that exhausted through hoods. Often humidity control is very important and the number of air changes used can meet the sensible load with moderate temperature air. As a result, over cooling and reheat is often used. Preconditioning can reduce energy consumption significantly and improve humidity control.
Potential market for this application using some type of preconditioning (Estimates for 1996)

Total outdoor air CFM for segment

$$
\$ 16,142,100 \text { per year* }
$$

* (assumes $50 \%$ chemical $/ 50 \%$ biological and other labs)

\begin{tabular}{|c|c|c|c|}
\hline Preconditioning Approach & $\begin{array}{c}\text { Rank Likelihood } \\
\text { of Utilization }\end{array}$ & $\begin{array}{c}\text { \% of Estimated } \\
\text { Available Market }\end{array}$ & $\begin{array}{c}\text { Estimated Market } \\
\text { Potential }\end{array}$ \\
\hline Conventional Cooling w/ Reheat & 1 & 40 & $\$ 2,964,000$ \\
Conventional w/ Heat Pipe & 4 & 15 & $\$ 1,930,500$ \\
Conventional with Total Recovery & 2 & 20 & $\$ 3,510,000$ \\
$\begin{array}{c}\text { Total Recovery Dual Wheel } \\
\text { DBC approach }\end{array}$ & 6 & 20 & $\$ 514,800$ \\
$\begin{array}{c}\text { Hybrid Total Recovery } \\
\text { Desiccant Dehumidification approach } \\
\text { Hybrid Total Recovery } \\
\text { DBC approach }\end{array}$ & 5 & 3 & $\$ 6,240,000$ \\
\end{tabular}

- Conclusions and Comments Regarding the Desiccant Based Preconditioning Market:

Research laboratories that are located where demand charges are high and there are a large number of hours per year where dehumidification is needed (humid climate), then a regenerated desiccant approach becomes justifiable. Low cost steam is often available for regeneration which is a plus. The co-sorption of pollutants is a significant benefit to many laboratory facilities. In this market, energy efficiency and system performance usually is more important than first cost. Some laboratories have a need for humidity conditions drier than obtainable from conventional cooling approaches. Non-regencrated desiccant total recovery is often avoided due to the contaminants in the exhaust airstream or the lack of a central exhaust location (ie: numerous exhaust fans) 


\section{Final Market Segment Analysis: Fast Food Restaurants}

Benefits provided by preconditioning of outdoor air loads

Potential market for this application using some type of preconditioning (Estimates for 1996)

Total outdoor air CFM for segment
The exhaust air required in the kitchen and the use of packaged equipment makes maintaining humidity within fast food restaurants very difficult in humid regions. Preconditioning outdoor air solves this problem. Increased outdoor air is also required if these facilities try to accommodate smokers. Wash down of the floors and cooking adds significant latent load to these spaces which cannot be effectively handled with packaged equipment.

$$
\$ 110,960,000 \text { per year }^{*}
$$

* ( assumes all buildings comply with ASHRAE 62-89)

$20,000,000 \mathrm{CFM}$

\begin{tabular}{|c|c|c|c|}
\hline Preconditioning Approach & $\begin{array}{c}\text { Rank Likelihood } \\
\text { of Utilization }\end{array}$ & $\begin{array}{c}\text { \% of Estimated } \\
\text { Available Market }\end{array}$ & $\begin{array}{c}\text { \$ Estimated Market } \\
\text { Potential }\end{array}$ \\
\hline Conventional Cooling w/ Reheat & 1 & 70 & $56,430,000$ \\
Conventional w/ Heat Pipe & 2 & 20 & $28,010,000$ \\
Conventional with Total Recovery & 4 & 5 & $9,550,000$ \\
Total Recovery Dual Wheel & 5 & 0 & $16,970,000$ \\
DBC approach & 3 & 5 & 0 \\
$\begin{array}{c}\text { Hybrid Total Recovery } \\
\text { Desiccant Dehumidification approach } \\
\text { Hybrid Total Recovery } \\
\text { DBC approach }\end{array}$ & 6 & 7 & 0 \\
\hline
\end{tabular}

- Conclusions and Comments Regarding the Desiccant Based Preconditioning Market:

Since there is seldom a return air path available in a fast food restaurant, recovery is not a viable option except in larger restaurants designed to relieve cigarette smoke. In humid climates, a market for some type of DBC exists, but the product would have to be very low cost and require minimal routine maintenance. A successful product would likely be a module to augment a packaged HVAC product. The product would have to be regenerated with a gas bumer or with energy released by a DX evaporator coil. 


\section{Final Market Segment Analysis: Retail Stores}

Benefits provided by preconditioning of outdoor air loads
The increased outdoor air loads associated with ASHRAE $62-89$ can increase project first cost and operating cost significantly. Preconditioning can cut demand charges significantly, assure acceptable humidity control in humid climates, and help conventional packaged units perform with constant outdoor air loads. Removing additional moisture to deal with humidity storage within the goods displayed in the facility may be a key benefit.

$$
\$ 58,266,000 \text { per year }{ }^{*}
$$
using some type of preconditioning (Estimates for 1996)

* ( assumes all buildings comply with ASHRAE 62-89)

Total outdoor air CFM for segment

$31,200,000 \mathrm{CFM}$

\begin{tabular}{|c|c|c|c|}
\hline Preconditioning Approach & $\begin{array}{c}\text { Rank Likelihood } \\
\text { of Utilization }\end{array}$ & $\begin{array}{c}\text { \% of Estimated } \\
\text { Available Market }\end{array}$ & $\begin{array}{c}\text { Estimated Market } \\
\text { Potential }\end{array}$ \\
\hline Conventional Cooling w/ Reheat & 1 & 40 & $11,856,000$ \\
Conventional w/ Heat Pipe & 4 & 15 & $7,722,000$ \\
Conventional with Total Recovery & 2 & 30 & $21,060,000$ \\
Total Recovery Dual Wheel & 5 & 5 & $5,148,000$ \\
DBC approach & 3 & 0 & $12,480,000$ \\
$\begin{array}{c}\text { Hybrid Total Recovery } \\
\text { Desiccant Dehumidification approach }\end{array}$ & 6 & 0 & \\
$\begin{array}{c}\text { Hybrid Total Recovery } \\
\text { DBC approach }\end{array}$ & 7 & 10 & \\
\hline
\end{tabular}

- Conclusions and Comments Regarding the Desiccant Based Preconditioning Market:

Superstores" offer the most potential for regenerated desiccant products in this market since thcy integrate both retail and food store functions under one roof. Regenerated desiccant systems provide a significant benefit to food stores that have freezer casings since lower dew-points result in fewer defrost cycles, lower operating costs and improved shopper comfort. Large retail stores (ie: Bloomingdale's) benefit from desiccant preconditioning since the large quantity of goods (ie. clothing) act as a moisture sink, making humidity control extremely difficult. Small shopping malls and retail stores without freezer arcas would likely incorporate a non-regenerated desiccant approach combined with a unitary package AC unit. Note that for most retail stores designed to accommodate the ASHRAE 62-89 standard, the exhaust air is available from the return air path. Also note that supermarket applications process both outdoor and return air, so market number is larger than shown above for regenerated DBC in retail stores. 


\section{Final Market Segment Analysis: Hotels and Dormitories}

Benefits provided by preconditioning of outdoor air loads
The exhaust air from bathrooms needs to be replaced making some of these facilities high outdoor air applications. Often the humidity associated with showers is very high for the conventional room air-conditioners to handle. Preconditioning outdoor air to handle these fluctuating loads provides benefits to comfort, energy efficiency and limits microbial and moisture damage resulting in a significant cost savings to this market segment.
Potential market for this application using some type of preconditioning (Estimates for 1996)

Total outdoor air CFM for segment
$\$ 76,927,500$ per year*

* ( assumes all buildings comply with ASHRAE 62-89)

\begin{tabular}{|c|c|c|c|}
\hline Preconditioning Approach & $\begin{array}{c}\text { Rank Likelihood } \\
\text { of Utilization }\end{array}$ & $\begin{array}{c}\text { \% of Estimated } \\
\text { Available Market }\end{array}$ & $\begin{array}{c}\text { Estimated Market } \\
\text { Potential }\end{array}$ \\
\hline Conventional Cooling w/ Reheat & 1 & 40 & $\$ 14,820,000$ \\
Conventional w/ Heat Pipe & 4 & 15 & $\$ 9,652,500$ \\
Conventional with Total Recovery & 2 & 20 & $\$ 17,550,000$ \\
Total Recovery Dual Wheel & 3 & 15 & $\$ 19,305,000$ \\
DBC approach & 5 & 10 & $\$ 15,600,000$ \\
$\begin{array}{c}\text { Hybrid Total Recovery } \\
\text { Desiccant Dehumidification approach }\end{array}$ & 6 & 0 & \\
$\begin{array}{c}\text { Hybrid Total Recovery } \\
\text { DBC approach }\end{array}$ & 7 & 0 & \\
\hline
\end{tabular}

- Conclusions and Comments Regarding the Desiccant Based Preconditioning Market:

The market for regenerated desiccant preconditioning is limited to large facilities located in humid climates and where a return/exhaust air path is not available for non-regenerated desiccant based recovery. Humidity conditions can be controlled as desired with the total recovery dual wheel approach which also utilizes conventional cooling technology and provides heating mode recovery, important for almost all applications. Humidity control is important for this market, independent of the method used to obtain it, since the hotel industry spends a significant amount on refurbishment to rooms and corridors annually due to humidity and microbial problems. 


\section{Final Market Segment Analysis: Movie Theaters and Auditoriums}

Benefits provided by preconditioning of outdoor air loads
The increased outdoor air loads associated with ASHRAE 62-89 can increase project first cost and operating cost significantly. Preconditioning can cut demand charges significantly, assure acceptable humidity control in humid climates, and help conventional packaged units perform with constant outdoor air loads.
Potential market for this application using some type of preconditioning (Estimates for 1996)

Total outdoor air CFM for segment
$\$ 30,082,500$ per year*

$21,000,000$ CFM

\begin{tabular}{|c|c|c|c|}
\hline Preconditioning Approach & $\begin{array}{c}\text { Rank Likelihood } \\
\text { of Utilization }\end{array}$ & $\begin{array}{c}\% \text { of Estimated } \\
\text { Available Market }\end{array}$ & $\begin{array}{c}\text { \$ Estimated Market } \\
\text { Potential }\end{array}$ \\
\hline Conventional Cooling w/ Reheat & 1 & 60 & $\$ 11,970,000$ \\
Conventional w/ Heat Pipe & 3 & 15 & $\$ 5,197,500$ \\
Conventional with Total Recovery & 2 & 5 & $\$ 9,450,000$ \\
Total Recovery Dual Wheel & 4 & 0 & $\$ 3,465,000$ \\
DBC approach & 5 & 0 & \\
$\begin{array}{c}\text { Hybrid Total Recovery } \\
\text { Desiccant Dehumidification approach } \\
\text { Hybrid Total Recovery } \\
\text { DBC approach }\end{array}$ & 6 & 7 & 0 \\
\hline
\end{tabular}

- Conclusions and Comments Regarding the Desiccant Based Preconditioning Market:

This is a very price sensitive market. Humidity control is not very important based on survey. No free energy available for regeneration and low hours of operation at peak occupancy, making energy efficiency a difficult sell. If designed to accommodate the ASHRAE 62-89 standard and located in an area with high demand charges, non-regenerated total energy recovery is a viable approach. There is always a return air path available to provide the exhaust required by total recovery.

This market shows little opportunity for regenerated desiccant approaches. 
E-12 
ORNL/Sub/94-SV044/1

\section{INTERNAL DISTRIBUTION}

\author{
1. J. E. Christian \\ 2. G. E. Courville \\ 3. T. R. Curlee \\ 4. R. C. Devault \\ 5. P. D. Fairchild \\ 6. M. A. Karnitz \\ 7. C. I. Moser
}

\author{
8-29. J. R. Sand \\ 30. A. Schaffhauser \\ 31. R. B. Shelton \\ 32. E. A. Vineyard \\ 33. Laboratory Records-RC \\ 34. Central Research Library \\ 35-36. OSTI
}

\section{EXTERNAL DISTRIBUTION}

37. Lilia A. Abron, PEER Consultants, 1460 Gulf Blvd., Apt. 1103, Clearwater, FL 33767

38. Joel Anderson, Mississippi Valley Gas Company, P.O. Box 3348, Jackson, MS 39207

39. Ren Anderson, National Renewable Energy Laboratory, 1617 Cole Blvd., Golden, CO 80401-3393

40. Frank Ballistreri, Reliant Energy-Minnegasco, P.O. Box 59038, 15th Floor, 800 LaSalle Ave., Minneapolis, MN 55459-0038

41. Douglas Bauer, Commission on Engineering and Technical Systems, National Research Council, Harris 280, 2001 Wisconsin Ave. NW, Washington, D.C., 20007

42. John C. Brady, Mechanical Engineering, ATS\&R, 8501 Golden Valley Rd., \#300, Minneapolis, MN 55427

43. Paul L. Brillhart, University of Illinois-Chicago, Energy Resources Center, 1223 SEO, 842 West Taylor St., Chicago, IL 60607-7022

44. Thom Clemens, Desicair Sales Manager, ATS, 1572 Tilco Dr., Fredrick, MD 21701

45. Susan L. Cutter, Hazards Research Laboratory, Department of Geography, University of South Carolina, Columbia, SC 20208

46. John Fischer, SEMCO, Inc., 737 Terrell Crossing, Marietta, GA 30067

47. R. Fiskum, U.S. Department of Energy, EE-42, 5E-036/Forrestal, Washington, D.C. 20585

48. P. W. Garland, UT-Battelle, LLC, 901 D St. SW, Suite 900, Washington, D.C. 20024

49. Arthur D. Hallstrom, Air Handling Systems, The Trane Company, 1500 Mercer Rd., Lexington, KY 40511

50. Lew Harriman, Mason-Grant Consulting, P.O. Box 6547, 57 South St., Portsmouth, NH 03802

51. Stephen G. Hildenbrand, Environmental Sciences Division, Oak Ridge National Laboratory, P.O. Box 2008, Oak Ridge, TN 37831-6037

52. Keith Hodge, Department of Mechanical Engineering, 210 Carpenter Engineering Bldg., P.O. Drawer ME, Mississippi State, MS 39762-5925

53. John Kelly, IGT, 1700 S. Mount Prospect Rd., Des Plaines, IL 60018-1804

54. Douglas R. Kosar, Gas Research Institute, 8600 West Bryn Mawr Ave., Chicago, IL 60631-3562.

55. Tony Occhionero, American Gas Cooling Center, 400 N. Capitol St., NW, Washington, D.C. 20001

56. P. Richard Rittelmann, Burt Hill Kosar Rittelmann Associates, 400 Morgan Center, Butler, PA $16001-5977$

57. Mike Schell, Telaire, 6489 Calle Reale, Goleta, C.A 93117

58. David Simkins, Munters Corporation, P.O. Box 640, Amesbury, MA 01913

59. Steven Slayzak, Center for Buildings and Thermal Systems, National Renewable Energy Laboratory, 1617 Cole Blvd., Golden, CO 80401-3393 
